\title{
DNA Sequence-Based Identification and Molecular Phylogeny \\ Within Subfamily Dipterocarpoideae (Dipterocarpaceae)
}

\author{
Dissertation
}

Submitted in partial fulfillment of the requirements for the degree of Doctor of Philosophy (Ph.D.)

at Forest Genetics and Forest Tree Breeding, Büsgen Institute Faculty of Forest Sciences and Forest Ecology Georg-August-Universität Göttingen

By

Essy Harnelly

(Born in Banda Aceh, Indonesia)

Göttingen, 2013 
Supervisor

Referee

Co-referee

Date of Disputation
: Prof. Dr. Reiner Finkeldey

: Prof. Dr. Reiner Finkeldey

: Prof. Dr. Holger Kreft

: 09.01 .2013 
To My Family 


\section{Acknowledgments}

First of all, I would like to express my deepest gratitude to Prof. Dr. Reiner Finkeldey for accepting me as his $\mathrm{PhD}$ student, for his support, helpful advice and guidance throughout my study. I am very grateful that he gave me this valuable chance to join his highly motivated international working group. I would like to thank Prof. Dr. Holger Kreft and Prof. Dr. Raphl Mitlöhner, who agreed to be my co-referee and member of examination team.

I am grateful to Dr. Kathleen Prinz for her guidance, advice and support throughout my research as well as during the writing process. My deepest thankfulness goes to Dr. Sarah Seifert (in memoriam) for valuable discussion of my topic, summary translation and proof reading. I would also acknowledge Dr. Barbara Vornam for her guidance and numerous valuable discussions about my research topic. I would present my deep appreciation to Dr. Amarylis Vidalis, for her brilliant ideas to improve my understanding of my project.

My sincere thanks are to Prof. Dr. Elizabeth Gillet for various enlightening discussions not only about the statistical matter, but also my health issues. Many thanks are to Prof. Dr. Martin Ziehe for his support and recommendation to DAAD. I am also grateful to get acquainted with Alexandra Dolynska, who gave me enormous helps during my lab works. Without her help it would be difficult for me to finish my study on time. I would also like to acknowledge Gerold Dinkel for his help to solve computer problem. My thanks also go to Regina Berkeley, who always helps me with the administration matters during my study.

I would like to acknowledge former students: Dr. Nga Phi Nguyen, Dr. Yanti Rachmayanti, and Dr. Hani Siti Nuroniah for the data and discussion. Many thanks to my roommates: Dr. Alexandra Kuchma and Dr. Yazar Minn, for their kindness, help and support during my stay in Germany. I also would like to thank all my friend in the Institute; Randy Villarin, Konstantina Kameubun, Dr. Rajendra K.C., Dr. Chunxia Chung, Dr. Marius Ekue, Markus Müller, Fitri Yola Amandita, and Crusty Estoque, for knowledge sharing and discussion.

I need to acknowledge the Aceh government for granting me the scholarship, and Syiah Kuala University for allowing me to take study leave overseas. I would also like to acknowledge The German academic exchange service (DAAD) who gives me their best assistant during my study in Germany. 
My sincerest thanks to all Acehnese student societies in Germany for their kind support, to my friends from Aceh in Göttingen for making me feel like home, especially to Maimun Rizal, Ikhlas Ali Amran, Rezky Syahrezal, Ichsan, Rita Khathir, Faradilla Fadlia and Febi Mutia for their help and support during my study. I also appreciate the Indonesian community for their support and warm friendship during my study in Göttingen. Many thanks to Dr. Siti Nurleily Marliana and Alex for proof reading this dissertation. I would like to deliver my sincere thanks to my best friends in Biology Department Syiah Kuala University: Betty Mauliya, Zumaidar, Yekki Yasmin, Fauziah and Leni Fitri, who always give support and caring during my study.

My deepest gratitude to my mother (in memoriam), who has a dream about going to Germany, which finally drove me to this country, to my mother in law for her support and prayer throughout my study, and to my brothers and sisters for their love and caring. My sincere thanks to my sister Enny Rohainy and her husband Prof. Dr. Herry Suhardiyanto for their love and support in my life. I would also like to acknowledge the support and warm discussion with my niece, Asadatun Abdullah.

Finally, I would like to express my profound gratitude to my husband, Eka Oktavianus, for his patient, love, and encouragement, as well as to my great children: Shofiya Assyifa, Adullah Abdul Aziz, and Najiya Assyifa, who showed me their brave, patient, and independent that made my study life easier. 


\section{Content}

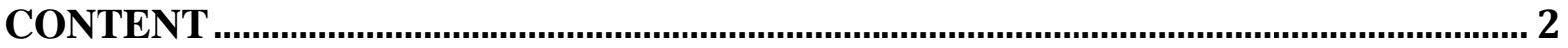

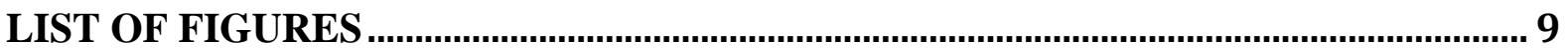

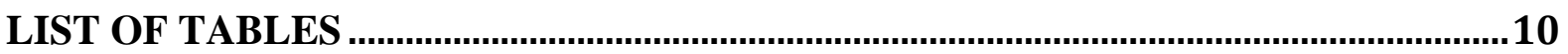

1 INTRODUCTION .................................................................................11

1.1 Background of the study ---

1.2 The Requirement of Molecular Taxonomic Tools ---o--o 12

1.3 Molecular Identification Tools for Dipterocarps - 14

1.4 Rationale of the study---on

$2 \quad$ PLANT MOLECULAR SYSTEMATICS ......................................................16

2.1 DNA Sequence Data - 16

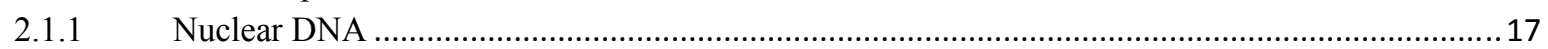

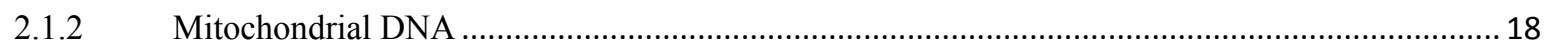

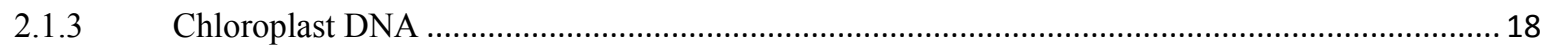

$2.2 \quad$ Molecular phylogenies of plants --o- 21

2.3 DNA-based identification -- 23

2.4 DNA barcoding -- 23

2.5 Molecular taxonomic identification key --o---o- 25

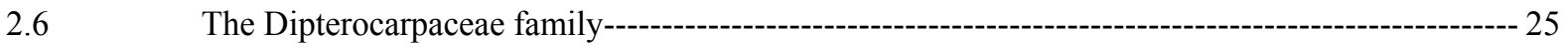

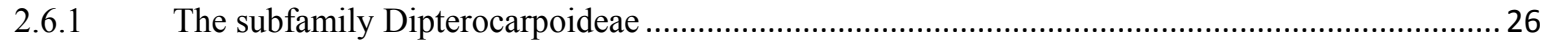

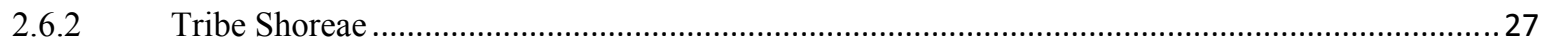

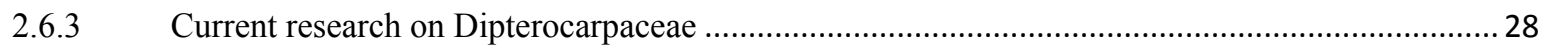

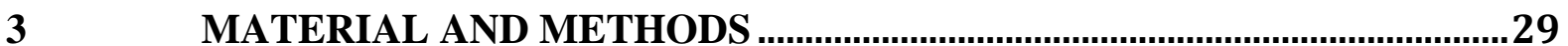

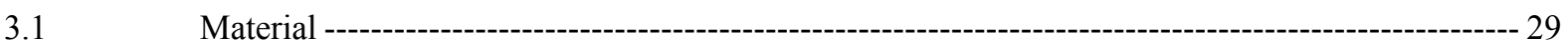

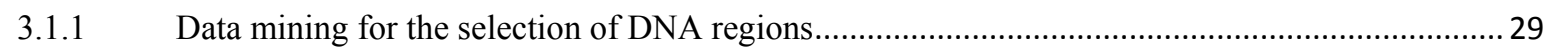

3.1.2 Additional sequence information from leaf collections ................................................................29

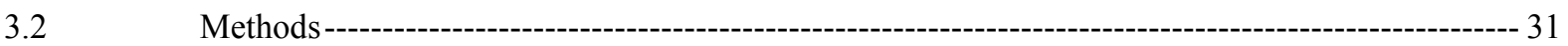

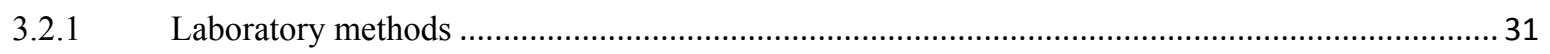

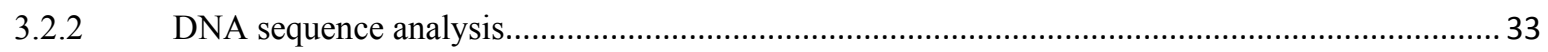




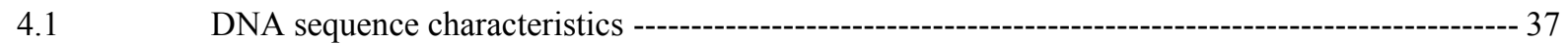

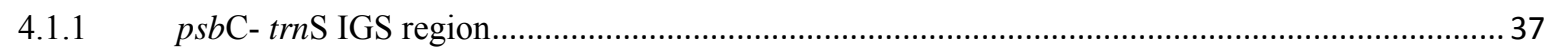

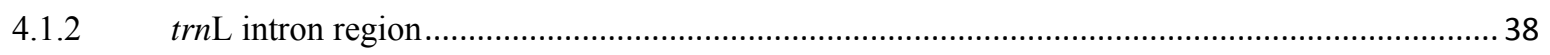

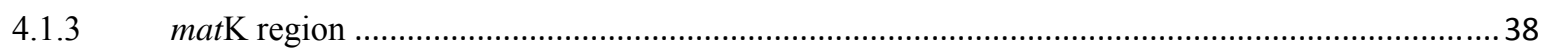

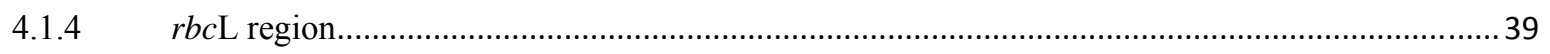

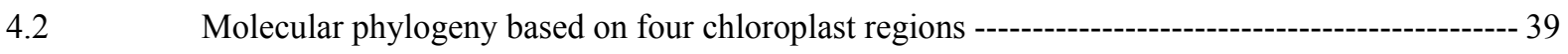

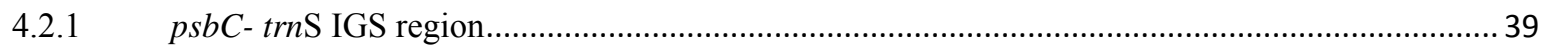

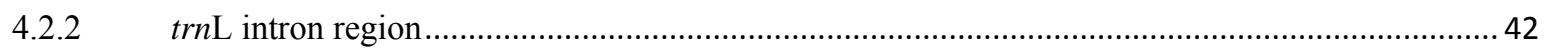

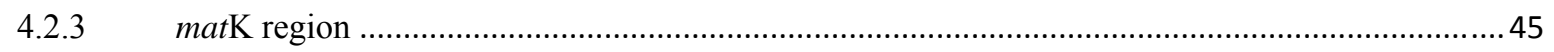

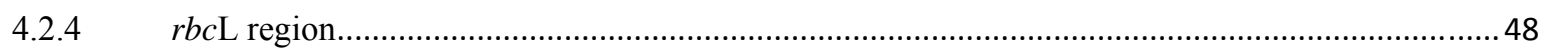

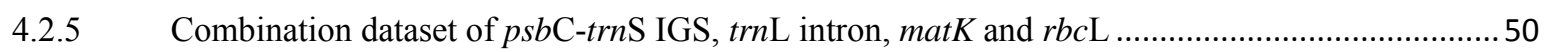

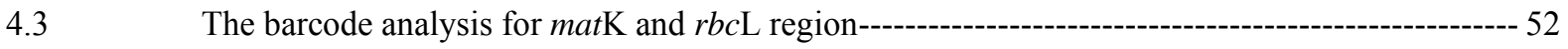

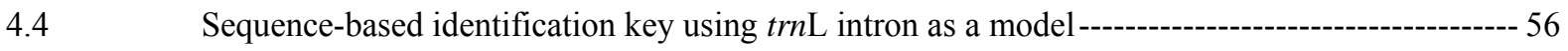

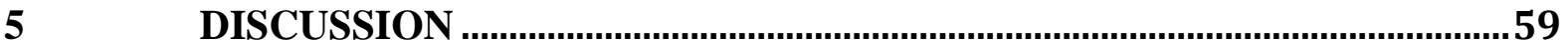

5.1 The phylogeny of Dipterocarpoideae ------------------------------------------------------------------ 59

5.1.1 Combination of four chloroplast DNA regions and overview of single regions ..........................59

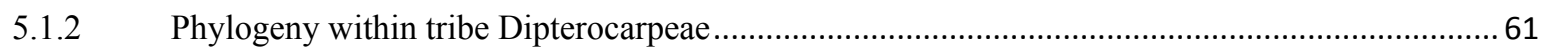

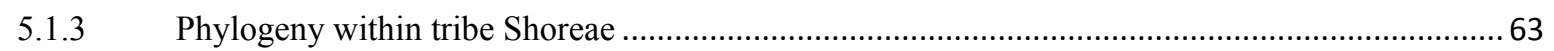

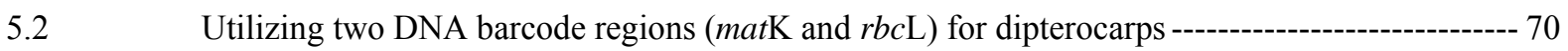

5.3 Sequence-based identification key --- 31

6 CONCLUSION AND OUTLOOK ............................................................. 72

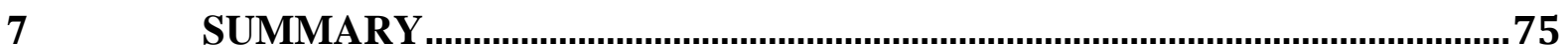

8 ZUSAMMENFASSUNG ............................................................................. 79

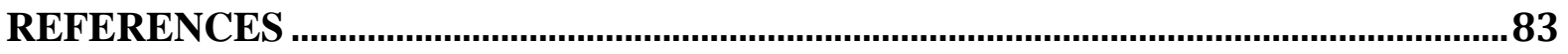

APPENDICES.................................................................................................................... 91

Appendix 1. List of plant species and corresponding GenBank accession numbers retrieved from the

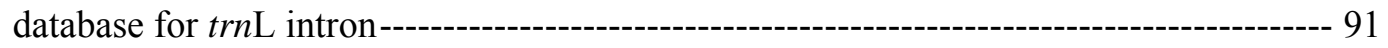

Appendix 2. The tree of trnL intron using Maximum Likelihood method based on the Kimura 2parameter model

Appendix 3. The tree of trnL intron using the neighbor joining method and using the Kimura 2parameter for genetic distance 104 
Appendix 4. The tree of psbC-trnS IGS using the maximum likelihood method based on the Kimura 2-parameter model

Appendix 5. The psbC-trnS IGS tree using neighbor joining method and Kimura 2-parameter------ 106

Appendix 6. The tree of matK gene using Maximum Likelihood method based on the Kimura 2parameter model

Appendix 7. The tree of matK gene using the neighbor joining method and Kimura 2-parameter -- 108

Appendix 8. The tree of $r b c \mathrm{~L}$ gene using the maximum likelihood method based on the Kimura 2parameter model

Appendix 9. The tree of $r b c \mathrm{~L}$ gene using the neighbor joining method based on the Kimura 2parameter

Appendix 10. The identification test of matK (barcode region) using the neighbor joining analysis method with $\mathrm{K} 2 \mathrm{P}$ formula as a parameter for genetic distance

Appendix 11. The identification test of $r b c \mathrm{~L}$ (barcode region) using the neighbor joining analysis method with K2P formula as a parameter for genetic distance

Appendix 12. The cladogram of trnL intron tree using maximum parsimony analysis and the molecular taxonomic identification key based on the clades of the tree 


\section{List of Figures}

Fig 2.1 The internal transcribed spacer (ITSs) of nuclear ribosomal DNA scheme

Fig 2.2 The scheme of chloroplast genome with three exons, an intron and an intergenic spacer .......19

Fig 2.3 The Distribution map of Dipterocarpaceae in South America, Africa and Asia .....................26

Fig 4.1 The tree of the $p s b C-t r n S$ region using maximum parsimony method.................................... 41

Fig 4.2 The tree of $t r n \mathrm{~L}$ intron using maximum parsimony method................................................. 43

Fig 4.3 The tree of matK region using the maximum parsimony method ........................................46

Fig 4.4 The tree of $r b c L$ gene using the maximum parsimony method............................................49

Fig 4.5 The combination dataset trees using different statistical method...........................................51

Fig 4.6 The neighbor joining tree of combined dataset matK and $r b c \mathrm{~L}$ (1282 nucleotides) using Kimura2 Parameter distance method..

Fig 5.1 Comparison of classification of Shorea and its closely-related genera adopted from Kamiya et al. (2005) 


\section{List of Tables}

Table 3.1 List of additional species from the collection of the Section Forest Genetics and Forest Tree

Breeding, Göttingen University 30

Table 3.2 Primers used in the present study.

Table 3.3 Reaction mixture of PCR reagents.

Table 3.4 Temperature profiles for PCR reactions 32

Table 3.5 Reaction mix of PCR Sequencing reagents .33

Table 3.6 Temperature Profiles for Sequencing PCR reactions .33

Table 3.7 Table for polymorphic sites of the species and their nucleotides. 35

Table 4.1 The sequence information of four chloroplast regions

Table 4.2 Sequence characteristics of four chloroplast regions 38

Table 4.3 The best match hits of matK sequence samples from laboratory samples using nBlast and Megablast for highly similar sequences. 55 


\section{Introduction}

\subsection{Background of the study}

Taxonomy has been in development for more than 250 years. However, only about 1.7 million species have been identified so far (Hawksworth, 1995). Approximately $86 \%$ of the species on earth still remain unknown, despite Carolus Linnaeus' introduction of the modern taxonomic system in 1758 (Lawton and May, 1995; Mora et al., 2011). The decrease of taxonomist is one of the impediment in limiting our understanding of species diversity in plants. Traditional taxonomic practices that are mainly based on morphological characters have a limited potential to enhance our understanding of species diversity in plants.

There are at least three problems in identifying plant species using traditional taxonomic practices: (a) limited literature and herbaria data access (Meyer and Paulay, 2005), (b) misidentification of a taxon because of the resilience of a taxonomic trait, and (c) high time consumption. Moreover, the lack of trained taxonomists and parataxonomists, particularly in biodiversity hotspots in developing countries, is another problem that needs to be overcome.

Furthermore, the rapid decline of plant species as a result of many factors such as climate change and illegal logging are encouraging plant taxonomists to find fast and accurate methods of plant species identification before they become extinct (Finkeldey et al., 2010; Meyer and Paulay, 2005). The fast growth of DNA sequencing technologies in the past 20 years opens opportunities to resolve the mentioned problems.

Besides relying on morphological characters, plant taxonomists increasingly use molecular data. Much research has been done on the reliability of molecular data in supporting the plant identification system (Finkeldey et al., 2010; Nuroniah et al., 2010; Wesselink and Kuiper, 2008).

Therefore, in an attempt to find a fast and accurate method of plant identification, the main goal of this study is to develop a molecular identification key based on chloroplast regions using the subfamily Dipterocarpoideae as an object. More details about the project and the plant tribe used will be explained in separate chapters. 


\subsection{The Requirement of Molecular Taxonomic Tools}

Molecular taxonomy is the classification of plant species using DNA data. These molecular methods provide broad taxonomic information for species delineation, which is available at the interspecific levels (Mayo et al., 2008). Generally, the comparison of species among lower or higher taxonomic levels by molecular systematic data requires a particular homologus region of the DNA sequence to be compared.

In 2003, Professor Paul Hebert from Guelph University proposed a quick, simple and economic tool for identifying biological diversity known as DNA barcoding (Hebert et al., 2003). This method involves comparing a short, standardized DNA region of an unknown species with that of a described species in a database. This method requires two components to obtain best results: a particular DNA sequence that has been named (Tautz et al., 2003) and high sequence variation of this DNA barcode. The mitochondrial region, coxI (cytochrome c and oxidase subunit 1) gene was at that time proposed as a standard DNA barcode. However, the implementation of this DNA barcode does not work as well in the identification of land plants as it does for animals. Thus, the coxI gene is only applied well in animal identification, moreover, the mitochondrial region in land plants has a high number of invariance, low rate of nucleotide substitution and non-conserved regions (Haider, 2011; Kress, 2005).

In an effort to determine the most reliable barcode region for land plants, chloroplast genes (cpDNA) were proposed. This is because cpDNA has quite conserved regions uniparental inheritance, is easy to isolate, and has stable genetic structure (Kress, 2005). Therefore, in 2009, The Plant Working Group in The Consortium for the Barcode of Life (CBOL) recommended the chloroplast regions $m a t K$ and $r b c \mathrm{~L}$ as a core barcode region for land plants because this sequences have high variation between species but low within species (Hollingsworth et al., 2011). Nevertheless, this barcode core for land plant is still debatable because both matK and $r b c \mathrm{~L}$ sometimes fail to work in some plants (Roy et al., 2010). Therefore, until now there still no a universal barcode available for land plant. However, cpDNA regions are still extensively used for plant molecular phylogenies at different taxonomy ranks. This is because the non-coding region (intergenic spacer) of cpDNA are usually quite variable to accomplish systematic studies at lower taxonomic levels (Haider, 2011; Shaw et al., 2005). 
The discriminatory power proposed by DNA barcoding is based on sequences similarity and homology within species to conduct the identification. Sequence comparisons are facilitated by search tools such as Basic Local Alignment Tools (BLAST) and MEGABLAST to perform fast identification (Cowan and Fay, 2012). The user provides a query sequence before starting a BLAST search. The BLAST program will find regions of similarity between the query sequence against the sequence database in National Center for Biotechnology Information (NCBI) (Kerfeld and Scott, 2011). The higher the match query sequence to the reference sequence in NCBI the closer the sequence to that species. Unfortunately, these search tools cannot be used as taxon identification tools because they are unable to accurately differentiate between highly similar sequences (Little, 2011).

In addition, DNA barcoding needs the support of phylogenetic analyses. Normally, closely related sequences will indicate sister groups which indicate that these groups share a recent common ancestor (Soltis and Soltis, 2003). The phylogenetic tree will guide us to understand the genetic relationships of the organism as well as to figure out the evolutionary changes which happened during the time. Reliable DNA markers are very important as identification tools (Cawthorn et al., 2011).

Since DNA barcoding concepts are not well-established yet with regard to the definition of discriminatory regions especially for land plants, it is urgently needed to expand related concepts that can be used as tools to identify species. A promising concept is relying on the phylogenetic analysis which depends on DNA polymorphism among sequences so that it can be used as a discriminatory key to distinguish among species. This method can help to minimize misidentifications because it rests on comparative analyses of nucleotide differentiation as important characters to reveal similarities and differences among taxa. An identification key based on molecular sequence data can be a good alternative for identification purposes. The arrangement of the key will be based on the nucleotide polymorphism among sequences in monophyletic groups. The polymorphic nucleotides will be the character state to discriminate among species. This can be conducted because molecular sequence data and DNA molecular techniques are widely available now. 


\subsection{Molecular Identification Tools for Dipterocarps}

The Dipterocarpaceae family plays a very important role as a source of timber in the tropical lowland rainforests of Southeast Asia. This family has three subfamilies, 17 genera and approximately 500 species that are spread across the tropical regions of Africa, Asia and South America (Ashton, 1982). Dipterocarpaceae sensu lato includes the following three subsubfamilies: Dipterocarpoideae in Asia, Pakaraimoideae in South America and Monotoideae in Africa and South America (Apanah, 1993).

The subfamily Dipterocarpoideae was selected as the subject of this study for the following reasons:

a. It has the highest number of species compared with the other subfamilies.

Dipterocarpoideae has approximately 400 species, and is considered to have high biological diversity (Ashton, 1982).

b. Species belonging to the subfamily have good timber quality.

It is well known that Dipterocarpoideae consists of many species with good timber quality, such as those in Shorea, the main genus in the subfamily.

c. Many species are threatened.

As a consequence of the high demand of good timber, many Dipterocarpoideae species are endangered (IUCN, 2011 )

To prevent a rapid decline of threatened forest species as a result of illegal logging, reliable and efficient tracing methods for forest tree species are urgently needed (Finkeldey et al., 2010). Although many countries have been using wood tags/wood labels to certify certain woods that can be cut down, many industrial wood processers fraudulently remove the labels. When the labels are removed, it is extremely difficult to distinguish the wood because of the high similarity in wood morphology and anatomy, but not necessarily in terms of DNA sequence variation. Therefore, DNA extraction protocols from woody tissue have been developed to apply molecular markers for wood certification (Rachmayanti et al., 2006).

Several molecular studies have attempted to develop tools for Dipterocarpaceae in the context of wood certification and timber forensic profiling. Rachmayanti et al. (2009) optimized DNA extraction protocols for Dipterocarp woods, and Nuroniah et al. (2009) developed a diagnostic marker for the identification of the tree species Shorea leprosula Miq. and Shorea 
parvifolia Dyer, as well as the geographic origin of Shorea leprosula Miq using specific PCR (Polymerase Chain Reaction) markers/SCAR (Sequence Characterized Amplified Region) markers. Tnah et al. (2010) developed STR markers of Neobalanocarpus hemii for forensic DNA profiling.

In addition, molecular analyses have been conducted to clarify phylogenetic relationships among Dipterocarpaceae species (Kajita et al., 1998; Morton, 1999; Kamiya et al., 2005; Ishiyama et al., 2003; Yulita et al., 2005, Indrioko et al., 2006). The taxonomic treatment and phylogenetic arrangement of taxa is particularly controversial for the species-rich genera Shorea and Hopea (Dayanandan et al., 1999; Yulita et al., 2005).

Recent advances in molecular sequence technologies have enabled rapid and reliable authentication of Dipterocarp timber. A specific molecular database has been promoted for classifying Shorea species and the technique has been used for checking the legitimacy of timber and wood products (Tsumura et al., 2011). This database enables the identification of Shorea and its closely-related species among Dipterocarps using the FASTA software (http://f5002.ffpri-108.affrc.go.jp/shorea/). However, for effective certification programs, the development of a database should go along with the enhanced use of advanced molecular taxonomic identification tools in order to reliably discriminate as many species as possible.

\subsection{Rationale of the study}

The aims of this study are to evaluate the suitability of the matK and $r b c \mathrm{~L}$ regions in distinguishing Dipterocarpaceae species and to study the possibility of developing a molecular taxonomic identification key for Dipterocarpaceae based on phylogenetic analyses. This study also aims to investigate partial sequences of four chloroplast DNA regions in order to elucidate the phylogenetic relationships within subfamily Dipterocarpoideae. 


\section{Plant molecular systematics}

Systematics refers to discovering, describing, naming, documenting and then classifying species based on phylogenetic analyses of evolutionary changes. Systematics plays a central role in the field of biology as the means of characterizing and identifying organisms (Schuh, 2000; Singh, 2004). One of the most important aspects of systematic and phylogenetic analyses is reconstructing the historical relationships of groups of biological organisms. A correctly inferred phylogeny may provide knowledge of species' relationships, which can then benefit studies in related fields as, for example, ecology and biogeography (Kreft and Jetz, 2010; Soltis and Soltis, 2003).

Plant molecular systematics can be defined as the use of genetic information, such as that obtained from nucleotides, to support taxonomic identification. In molecular systematic analyses, a hierarchy's arrangement is based on the homology of a DNA sequence from closely related species. The homology of DNA sequences needs to consider whether similar sequences share a common evolutionary history (Simpson, 2006). An advantage of using DNA sequences instead of morphological characters is related to the evolution of DNA sequences: DNA sequences maintain records of their ancient past as well as of their more recent history during evolution (Tautz et al., 2003).

The choice of a suitable DNA region is the most important consideration when inferring a phylogenetic relationship from molecular data (Soltis et al., 1998). The selection of a proper region is important since slowly evolving regions provide little information to the fullyresolved phylogeny, while quickly evolving regions lead to homoplasy as a result of multiple changes (Soltis and Soltis, 2000).

\subsection{DNA Sequence Data}

DNA sequencing is the process of determining the order of the nucleotide bases-A (adenine), G (guanine), C (cytosine) and T (thymine) present in a target DNA molecule. The process of DNA sequencing has been developing for over forty years. In the early-1970s, researchers used methods based on chromatography to obtain the first sequences. These techniques were followed by dye-based methods with automated analyses (Simpson, 2006). 
The fast advance in DNA sequencing technology in the late- $20^{\text {th }}$ century has resulted in a tremendously high amount of DNA sequences, also leading to advances in the concepts with which species are identified and classified. DNA sequence analyses became useful tools in helping taxonomists to characterize the evolutionary relationships between lineages, and even identify the early stages of speciation (Brinegar, 2009). Comparing the homology of DNA among understudied taxa will provide the characters that can be used to infer the phylogenetic relationships among a large number of species (Simpson, 2006).

The use of DNA sequences for phylogenetic analysis of evolutionary processes at the molecular level requires information contained in nuclear and extranuclear genomes. The three basic types of sequence data generated from the genomes are nuclear DNA (nDNA), chloroplast DNA (cpDNA) and mitochondrial DNA (mtDNA).

\subsubsection{Nuclear DNA}

Nuclear DNA is generally used in evolutionary as well as phylogenetic studies. Nuclear DNA is transmitted from parent to offspring by nuclear division through sexual or asexual reproduction (Simpson, 2006). Since a nuclear genome is biparentally inherited, it is expected to provide more information than a chloroplast or mitochondrial genome on species identity, including hybridization. One of the more useful types of nuclear DNA sequences is the internal transcribed spacer region (ITS), which contains multiple DNA copies. The ITS region lies between $18 \mathrm{~S}$ and 26S nuclear ribosomal DNA (nrDNA) (Fig. 2.1).

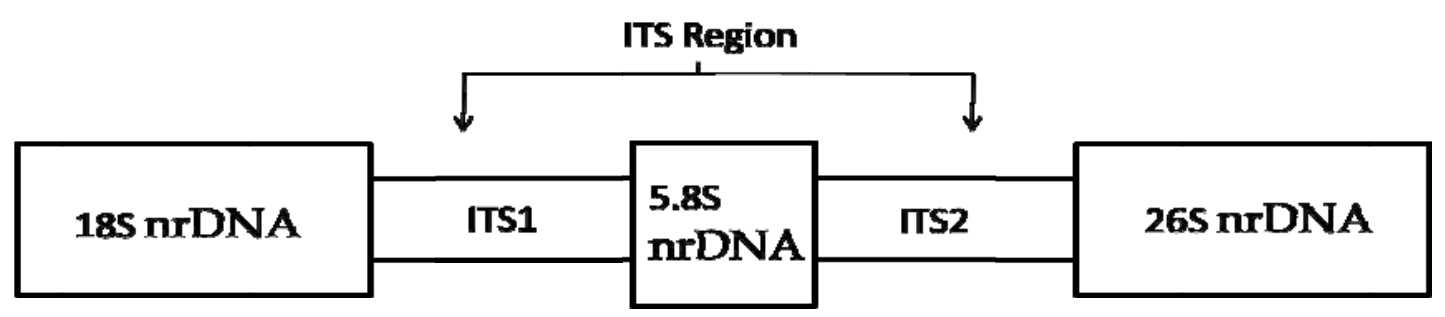

Fig 2.1 The internal transcribed spacer (ITSs) of nuclear ribosomal DNA scheme

Currently, ITS sequence data has been most valuable for inferring phylogenetic relationships at lower levels because this region is found in numerous copies in both animal and plant cells, 
biparentally inherited, and has the potential to distinguish between closely-related species. This region is recommended for inferring the phylogenetic relationship among plants because of intra-genomic variability and high mutation rates (Kress, 2005). Hollingsworth et al. (2009) advocates the use of the ITS region for plant species that have limited variation in the plastid genome.

\subsubsection{Mitochondrial DNA}

Mitochondrial genomes are ubiquitous throughout the eucaryotic cell, encoding necessary proteins involved in energy production, as well as playing an important role in the development and reproduction of the plant (Stuessy, 2008).

Mitochondrial DNA is not recommended as a source of phylogenetic information by plant systematists, since this region is poorly conserved. One of the reasons why this genome is not often used in systematic studies in plants is because it is large in size (ranging between 200 and $300 \mathrm{~kb}$ ), and it has widespread intra- and inter-molecular recombination. This genome is also not appropriate for most plant species because of a much slower rate of cytochrome c oxidase I gene evolution in vascular plants compared with animals (Kress, 2005).

\subsubsection{Chloroplast DNA}

The genomes of chloroplasts, which are responsible for photosynthesis, provide rich evolutionary and phylogenetic information. The chloroplast genome is most widely used as a source of information on the inference of the evolutionary patterns and processes of plants (Raubeson \& Jansen, 2005), because this genome is thought to evolve slowly, with low mutation rates and maternal inheritance in most angiosperms, along with being a conserved region in structure and gene order.

A chloroplast DNA marker that is maternally inherited shows more conserved DNA patterns compared with a nuclear gene that is biparentally inherited. Chloroplast DNA replicates and divides independently of the nucleus. The chloroplast genome can be divided into three functional categories: exons, introns and intergenic spacers (Fig. 2.2), the latter two of which 
do not encode proteins and are referred to as noncoding region (Shaw et al., 2005). Noncoding sequences such as introns and intergenic spacer regions of chloroplast DNA, became important tools in the phylogenetic analysis of a broad range of plant groups at a variety of taxonomic levels (Kelchner, 2000). These regions are supposed to evolve more rapidly than coding regions, enabling it to serve as a primary source of data for molecular systematic, phylogeographic, and population genetic studies of plants.

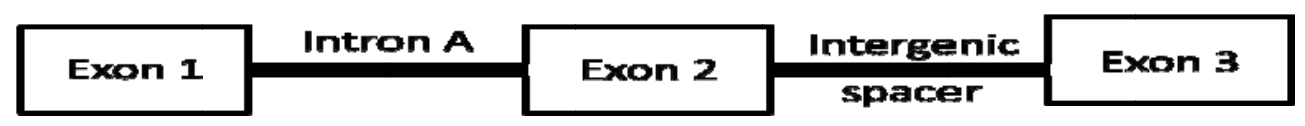

Fig 2.2 The scheme of chloroplast genome with three exons, an intron and an intergenic spacer

Noncoding chloroplast DNA sequences were first used to generate plant phylogenies when three noncoding regions were amplified by universal primers (Taberlet et al., 1991). In 1994, Gilley and Taberlet revealed that the noncoding chloroplast regions are more phylogenetically informative than the coding regions at lower taxonomic levels. This is because they can provide useful characters for phylogeny reconstruction based on a large number of mutations as shown for the genera Gentiana and Euphorbia (Gielly and Taberlet, 1994). There are many chloroplast regions used in phylogenetic studies. The following four chloroplast regions were frequently used in recent studies.

\subsubsection{1 trnL intron region}

The intron of the encoding chloroplast tRNA for Leucin (trn $\mathrm{L}_{\mathrm{UAA}}$ ), also known as the trnL intron, is presently widely used for reconstructing phylogenies between closely-related species and for identifying plant species (Zhou et al., 2008). This intron is present in almost all land plants and carophyte algae (Shaw et al., 2005). The location of the trnL intron is between the tandemly-arranged $\operatorname{trn} \mathrm{A}$ gen, $\operatorname{trn} \mathrm{T}_{\mathrm{UGU}}$ and $\operatorname{trn} \mathrm{F}_{\mathrm{GAA}}$ in the large single-copy region of the chloroplast genome in land plants (Taberlet et al., 1991). The length of this region in land plant chloroplasts varies between ca 250 and 1400 bp (Shaw et al., 2005). The region is often jointly amplified with the intergenic spacer trnL-trnF (Shaw, 2007). There are several reasons why the trnL group I intron and intergenic spacer between $\operatorname{trnL}$ and $t r n \mathrm{~F}$ are 
among the most widely-used noncoding DNA regions in plant systematics, namely they are easily amplified, the molecular structures are well known and present in nearly all plant taxa.

\subsubsection{2 pbsC-trnS IGS region}

The psbC gene is one of the plastid genes encoded for the subunit P680 protein (Photosystem II) that is important for photosynthesis. This gene lies within the large single-copy region (LSC) of the plastid genome. There is an intergenic spacer between the $p s b C$ and $\operatorname{trnS} \mathrm{S}_{(\mathrm{UGA})}$ genes that is not known to be used for phylogenetic studies, although it has shown potential during preliminary screenings as alternative plastid genes of sufficient length and variation for use in molecular phylogenetic studies in some plants (Graham and Olmstead, 2000). Sequence data on the $p s b C$-trnS region in Abies alba provides preliminary evidence of high intraspecific variation in the noncoding intergenic region compared with the highly conserved psbC gene sequence (Ziegenhagen and Fladung, 1997). This intergenic spacer region, combination with other gene regions succeeded to classify Shorea species (Tsumura et al., 2011).

\subsubsection{3 $r b c L$ region}

The ribulose-1, 5-bisphosphate carboxylase large subunit $(r b c \mathrm{~L})$ is encoded for the RuBisCO enzyme, which is important for photosynthesis. The $r b c \mathrm{~L}$ gene, the first gene to be sequenced in plants, exists as a single copy and contains no introns (Zurawski et al., 1981). Since it is one of the most conserved genes in the chloroplast genome, this gene has been widely used in molecular phylogenetic analysis. Because of this gene's conserved region, it is well known for its use as a tool to retrace the evolutionary history of plant groups that diverged a long time ago. Thus, even distantly-related plants will have sequences similar to each other.

The $r b c \mathrm{~L}$ gene, along with a few other highly conserved genes, has assisted in answering questions about the origins of some of the major flowering plant groups.

Most plant phylogenetic studies suggest that the $r b c \mathrm{~L}$ gene is best-used to reconstruct the evolutionary relationship until the generic level but not the species level (Soltis et al., 1998). Therefore, to increase the power of this gene for phylogenetic purposes, it should be combined with more variable region (Vijayan and Tsou, 2010). 


\subsubsection{4 matK region}

The chloroplast matK gene, which encodes a maturase enzyme, is one of the most-utilized genes in phylogenetic studies after $r b c \mathrm{~L}$ because it evolves nearly two to three times faster than $r b c L$ (Soltis et al., 1998). The matK sequence information data have been used successfully to resolve generic and even species-level relationships. The length of this region is about $1550 \mathrm{bp}$, located within the intron of the chloroplast gene trnK and embedded in the group II intron of the lysin gene trnK (Vijayan and Tsou, 2010).

The capability of this region as a marker for phylogeny construction is related to the observation that this gene evolves quickly and is abundant in the plant. The matK gene is also frequently used for phylogenetics studies, because with the flanking noncoding intron parts, it is able to co-amplify the gene, so that the complete trnK intron is increasingly used. As a consequence, the utility of this region could be extended to the inter- and intra specific level (Muller and Borsch, 2005). The matK gene is considered to be one of the most informative loci for determining phylogenetic relationships (Hilu et al., 2003).

The matK gene have been used to study the molecular phylogeny of Dipterocarpaceae in Southeast Asia (Kajita et al., 1998). Another research was done to infer the molecular phylogeny of the subfamily Dipterocarpoideae including 14 genera and 79 species (Gamage et al., 2006).

\subsection{Molecular phylogenies of plants}

A phylogenetic system classifies taxa based on the evolutionary relationship among them which are often illustrated in a phylogenetic tree (Wiley and Lieberman, 2011). A phylogenetic analysis that using DNA as an information is known as molecular phylogeny. Here, the DNA sequences are used as characters to construct the phylogenetic tree (Lemey et al., 2009).

The most important step before starting a molecular phylogenetic study is choosing the right DNA region and gene. There are several points that need to be considered when choosing the DNA region: (1) the gene should be universal for all species studied, and (2) variation among 
the sequences should not be too high or too low (Shaw et al., 2005). If the gene evolves too slowly, there will be very little variation among sequences, whereas if it evolves too fast, it will be difficult to get a reliable alignment of the sequence and estimation of the evolutionary distance.

The advantage of using cpDNA in molecular evolutionary studies has been emphasized by systematists, not only as it facilitates straightforward PCR amplification, as a result of the high copy number, but also because of its uniparental inheritance, which produces unambiguous ancestor descendant relationships where the confounding effect of recombination is alleviated (Birky, 1995).

The evolutionary history among the DNA or protein sequences can be revealed by a phylogeny tree. The trees are built to represent the relationship of the sequences to their ancestor and show which sequence are most closely related (Lemey et al., 2009). Statistical methods are needed to determine the tree topology and calculate the branch lengths that best describe the phylogenetic relationships of the aligned sequences in a dataset.

Many different statistical methods can be used for reconstructing the phylogenetic tree. These methods differ from each other in their assumptions and algorithms of the character state. The most common computational methods applied include distance methods such as Unweighted Pair - Group Methods with Arithmetic Mean (UPGMA) and Neighbour Joining (NJ), and discrete data methods, such as Maximum Parsimony (MP) and Maximum Likelihood (ML) and Bayesian method (Hall, 2011; Lemey et al., 2009; Zhu et al., 2010). The principle of distance methods are to calculate all pairwise distances of the sequences as a distance matrix and group the most similar sequences together. Character-based methods use each character data in all steps of the analysis. In the maximum parsimony method, the observed input sequences are explained with a minimum number of substitutions. In this method, the likely tree is the one that requires the fewest number of changes. Maximum likelihood tries to infer an evolutionary tree by finding a tree which maximizes the probability for the observed data (Hall, 2011; Tamura et al., 2011). 


\subsection{DNA-based identification}

Traditionally, taxa have been identified using morphological characters. Morphological characters have been used to identify species for centuries. It was only recently that botanists realized the limitations of taxonomic analyses based on morphological characters which are influenced by genetic and environmental factors (Tautz et al., 2003).

When no differentiating morphological characters are available, plant identification becomes increasingly challenging. Unclear morphological characters or specimens in poor condition, as well as the existence of cryptic taxa in which the species are reproductively isolated and morphologically similar can lead to misidentification (Hajibabaei et al., 2007; Zulkifli et al., 2012). With the increasing availability of molecular data, overcoming the limitations of morphological characters is much easier because DNA sequences will help to overcome some problems in plant systematics.

In principle, we can use DNA variation as a character to study systematics similar to how we use morphological characters. Even though molecular data have been widely used for species separation and identification throughout the past two decades (Mayo et al., 2008), this method is seen as a new concept requiring specific amplification of plant DNA to reveal enough variability to differentiate species (Ridgway et al., 2003).

\subsection{DNA barcoding}

DNA barcodes can be defined as short, standard DNA sequences that are used to identify species. This method allows the delimitation of an organism at any stage of development from a tiny tissue sample, whether it is fresh, broken or old. This method also helps to discover new species, which is particularly important for cryptogamic plants (Bell et al., 2012). This new molecular technique benefits from plant diversity surveys, especially those of closely-related species and species-rich genera lacking variation in morphological characters (Dick and Webb, 2012). DNA barcoding was first introduced by Paul Hebert when he succeeded in using a part of the mitochondrial region cytochrome oxidase subunit I (coxI) to discriminate animals (Hebert et al., 2003). This region, unfortunately, is not suitable for plants because of the slow rate of evolution of the plant mitochondrial genome (Chase et al., 2005). 
To coordinate works on DNA barcoding in eukaryotes, the Consortium for the Barcode of Life (CBOL) was established within the secretariat of the National Museum of Natural History in Washington in 2004. CBOL includes organizations and researchers working in the framework of this approach. The region selected as a DNA barcode, as well as standards of its use, should be approved and ratified by the Consortium. CBOL consists of five working groups, namely, the Data Analysis Working Group, Database Working Group, DNA Working Group, Technology Development Working Group, and, most noteworthy in the context of this review, the Plant Working Group (PWG CBOL).

The principle of this method is to compare the DNA barcode region from a query sample with an available sample in a DNA barcoding database. For this reason, an established DNA barcoding database is critical. The Barcode of Life Database BOLD provides an integrated platform that supports all phases of the analytical pathway, from specimen collection to validation (Ratnasingham and Hebert, 2007).

Searching for DNA barcodes in plants has so far proven to be a challenging task. An appropriate DNA region is necessary for plant. In September 2009, the Consortium for Barcode of Life (CBOL) approved $r b c \mathrm{~L}$ and $m a t K$ as the core barcodes for land plants, because $r b c \mathrm{~L}$ is easy to use, but has modest discriminatory power, while matK has higher discriminatory power, but lower universality. Peter Hollingsworth (2011), the chair of the Plant Working Group, explained that there are three important factors in DNA barcoding: standardization, minimalism and scalability. Thus, there should be one or more standard DNA regions that can apply to a large and diverse set of samples, and that enables them to be distinguished from one another. 


\subsection{Molecular taxonomic identification key}

An identification key can be defined as a tool to simplify the specimen identification. A good structured key provides clarity and convinience for the user (Wiley and Lieberman, 2011). During the species identification process, an identification device such as an identification key is required. The identification key, used to narrow down the identity of a taxon, is simply a series of questions consisting of contrasting statements. Traditionally, identification keys are constructed using morphological characters, but for a molecular taxonomic identification key, a DNA sequence serves as an analog. Here, we can use each base position in the gene as a character, and use the specific base that occurs there (A,T,C or $\mathrm{G})$ as a character state.

The construction of a dichotomous key starts with the first pair of leads deciding which base is true for the particular position, with the answer directing the user to a following question until the specimen is identified. There are always two possible bases in every site position. For a molecular identification key, the sites of the polymorphic base refer to a character while the polymorphic base in that position refers to the character state.

\subsection{The Dipterocarpaceae family}

The Dipterocarpaceae family plays an essential role as the main timber family in the tropical lowland rainforests of Southeast Asia. This family has approximately 470 species in 13 genera which are recognized as the Asian subfamily Dipterocarpoideae, 39 species in two African genera and a monotypic South American genus in the subfamily Monotoideae, and one species of one genus in the South American subfamily Pakaraimoideae (Ashton et al., 1984). Although the center of species diversity of this family is now located in Borneo and its surrounding regions, Ashton et al. (1984) suggest that subfamilies of Dipterocarpaceae originally invaded Asia by way of the Indian fragment of Gondwana (Fig. 2.3).

The name of the Dipterocarpaceae refers the family's characteristic fruit with two wings, which developed from persistent sepals (Ashton, 1982). The long sepals, in general, are considered to have evolved from ancestors that themselves did not have long sepals. This is seen in the family's relatives, none of which have long and persistent sepals (Suzuki \& Ashton, 1996). However, in some emergent trees, the wings have become redundant with the 
reduction of the larger fruits' propelling function, and species with more than two wings attached to their fruits are common a well.

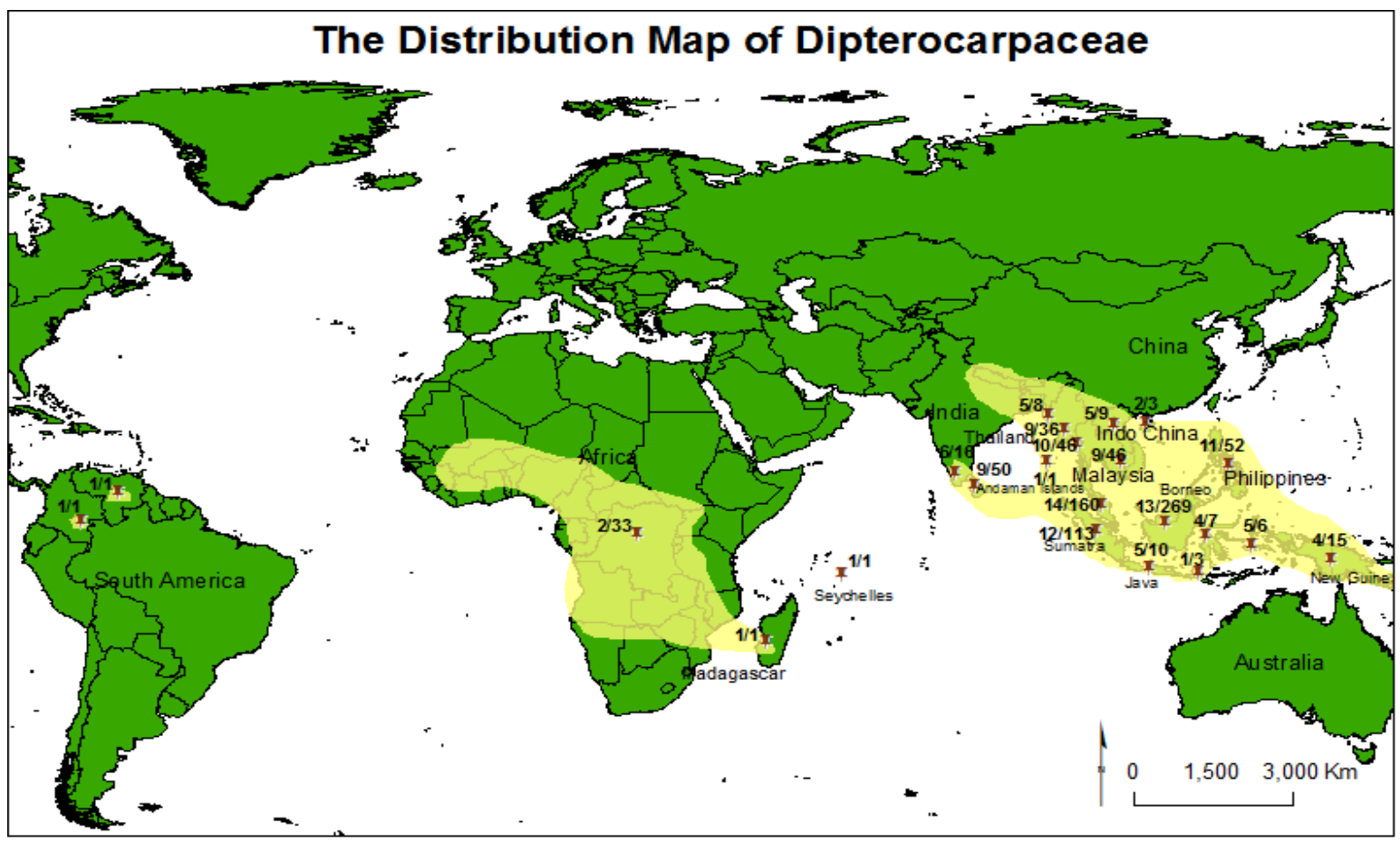

Fig 2.3 The Distribution map of Dipterocarpaceae in South America, Africa and Asia. The shaded areas indicate the extent of the family, labels indicate the numbers of genera/species (Symington, 1943)

Identification of Dipterocarpaceae is not an easy task, because some characteristics vary with a tree's age and habitat (Symington, 1943). Despite the difficulty created by this variability, Rath et al. (1998) reported that DNA polymorphisms are able to discriminate closely-related genotypes.

\subsubsection{The subfamily Dipterocarpoideae}

The Dipterocarpoideae is the most species-rich subfamily of the Dipterocarpaceae and the one with the highest diversity (Cao et al, 2006), with most of the species found in the genus Shorea. Classification of taxa within Dipterocarpoideae has been based on fruit, embryo and seedling characters, chromosome number and wood anatomy (Ashton, 1982; Maury \& Curted, 1998). Based on the chromosome number, this subfamily is divided into two tribes, Dipterocarpeae and Shoreae (Ashton, 1982), with haploid chromosome numbers of 11 and 
seven, respectively. Based on seed, embryo and seedling characters, (Maury et al., 1975) two main groups are recognized, one with imbricate fruit sepals and the other with valvate fruit sepals. The imbricate group includes two monophyletic genera, Hopea and Shorea, while the valvate clade includes Dipterocarpus and Vatica.

In conclusion, most taxonomists agree that the subfamily Dipterocarpoideae comprises two tribes, 13 genera, 17 sections and 12 sub sections. Separation of the tribe is based on the imbricate arrangement of fruit sepals and base chromosome number (Ashton, 1982). Tribe Dipterocarpeae consists of more than 150 species in eight genera (Dipterocarpus, Upuna Cotylelobium, Stemonoporus, Anisoptera, Vatica, Vateria and Vateriopsis) and four sections characterized by the valvate arrangement of the fruit sepals. The species rich tribe Shoreae comprises over 300 species (about 200 species of Shorea and over 100 species of Hopea) in five genera (Hopea, Shorea, Neobalanocarpus, Parashorea and Dryobalanops), 13 sections and 12 subsections The genus Dryobalanops has been considered an intermediate between the two groups and the type genus Dipterocarpus is recognized as a basal lineage of the subfamily Dipterocarpoideae (Maury and Curtet, 1998).

\subsubsection{Tribe Shoreae}

Shorea is the largest and economically most important genus in tribe Shoreae. Based on its wood's anatomy and how it is utilized, this genus can be classified into four sections: White Meranti, Yellow Meranti, Red Meranti and Balau (Selangan Batu), corresponding to the four sections Anthoshorea, Richetioides, Rubroshorea and Shorea (Symington, 1943). Compared with the other sections, Red Meranti's plywood is the most expensive.

The long - standing problem in placing Hopea and Shorea revealed that the taxa are not easily identified at the species level (Yulita et al., 2005). Ashton (1979) pointed out the difficulties in classifying Hopea, Shorea and Neobalanocarpus because of their morphological similarities. Several recent dipterocarp classification systems generally agree on the placement of Hopea and Shorea as two closely-related genera, although the placement of most species within these two genera is not clear (Whitmore, 1962; Meijer \& Wood, 1964; Meijer \& Wood, 1976; Maury-Lechon, 1979). 
The differences in the placement and circumscription of Hopea and Shorea result mainly from the use of different diagnostic characters for the genera and infrageneric groups. For example, Symington (1943) used wood anatomy to divide Shorea into four main groups. Ashton (1982) largely followed this classification, but recognized some of Symington's groups at a lower taxonomic rank, thus dividing Shorea into 11 sections and giving greater importance to the characters of the fruit calyx, androecium and bark.

Both Shorea and Hopea have remarkable similarities and exhibit continuous morphological variations at the generic, infrageneric and specific levels. Yulita et al. (2005) assumed that the similar characters between these two genera have led to the recognition of intermediate 'forms' or taxa. Examples of such intermediates are Parahopea, Parashorea and Richetia. This in turn has created controversy as to whether Hopea and Shorea should be placed as a single genus or be classified into different genera.

\subsubsection{Current research on Dipterocarpaceae}

Recent studies have focused on using molecular phylogenetic analysis to order some Dipterocarpaceae species (Kajita et al., 1998; Morton et al., 1999 ; Kamiya et al., 2005; Ishiyama et al., 2003; Indrioko et al., 2006; Yulita et al., 2005). The arrangement of taxa within the tribe of Dipterocarpaceae is easily identifiable, but taxonomists have long disagreed on the placement of different genera (Dayanandan et al., 1999; Yulita et al., 2005).

The phylogeny of Dipterocarpaceae has been assessed using several kinds of molecular methods, such as PCR-RFLP analysis of chloroplast genes (Tsumura et al., 1996; Indrioko et al., 2006), analyses of sequences of cpDNA regions (Kajita et al., 1998; Kamiya et al., 1998; Dayanandan et al., 1999), analyses internal transcribed spacer (ITS) regions (Yulita et al., 2005) and analysis of AFLPs (Cao et al., 2006).

Several molecular studies have been conducted for Dipterocarpaceae certification purposes and timber forensic profiling (Nuroniah et al., 2010; Rachmayanti et al., 2009). In 2010, Tnah et al. developed STR markers of Neobalanocarpus hemii for forensic DNA profiling. However, there is still insufficient information for robust molecular classification, and further sequence data, covering a greater range of species, are required (Tsumura et al., 2011). 


\section{Material and Methods}

\subsection{Material}

\subsubsection{Data mining for the selection of DNA regions}

Dipterocarpaceae molecular sequence data were retrieved from the NCBI website (http://www.ncbi.nlm.nih.gov/Taxonomy/). Homology searches were done by applying the Basic Local Alignment System Tools (BLAST) for nucleotides (nBLAST) in the NCBI database using the MEGABLAST algorithm for highly similar sequences from the public database website (http://blast.ncbi.nlm.nih.gov/Blast.cgi). The BLAST program takes the query sequence and searches for the best hits of similar sequence against the entire database of the sequences maintained at NCBI (Mount, 2007b). Prior data mining was done for all types of DNA markers deposited in the NCBI database to have an overview of the most abundant and reliable data for a molecular taxonomic key of Dipterocarpaceae. Based on prior data mining, metadata were developed to summarize the information about the DNA regions and taxa deposited in the NCBI database that were most frequently used by scientists. Those DNA regions and taxa were also selected for the present study.

\subsubsection{Additional sequence information from leaf collections}

Additional sequences were obtained from leaf collections that are available at the Section Forest Genetics and Forest Tree Breeding, Georg-August-University Göttingen. As a result, it was possible to analyze an additional 76 species (Table 3.1). These additional sequences also included outgroup samples from Monotoideae (Monotes kerstingii), which originates from Benin, Africa. 
Table 3.1 List of additional species from the collection of the Section Forest Genetics and Forest Tree Breeding, Göttingen University

\begin{tabular}{|c|c|c|c|c|c|}
\hline No & Species & Origin country & No & Species & Origin country \\
\hline 1 & Shorea lepida & Indonesia & 41 & Parashorea globosa & Indonesia \\
\hline 2 & Shorea latifolia & Indonesia & 42 & Shorea montigena & Indonesia \\
\hline 3 & Shorea fallax & Indonesia & 43 & Shorea javanica & Indonesia \\
\hline 4 & Shorea pinanga & Indonesia & 44 & Shorea andulensis & Indonesia \\
\hline 5 & Hopea mengarawan & Indonesia & 45 & Shorea johorensis & Indonesia \\
\hline 6 & Shorea platyclados & Indonesia & 46 & Shorea splendida & Indonesia \\
\hline 7 & Shorea guiso & Indonesia & 47 & Hopea malibato & Philippines \\
\hline 8 & Shorea palembanica & Indonesia & 48 & Hopea philippinensis & Philippines \\
\hline 9 & Shorea stenoptera & Indonesia & 49 & Hopea plagata & Philippines \\
\hline 10 & Hopea odorata & Indonesia & 50 & Parashorea malaanonan & Philippines \\
\hline 11 & Shorea leprosula & Indonesia & 51 & Shorea almon & Philippines \\
\hline 12 & Hopea dryobalanoides & Indonesia & 52 & Shorea astylosa & Philippines \\
\hline 13 & Shorea macrophylla & Indonesia & 53 & Shorea contorta & Philippines \\
\hline 14 & Shorea martiniana & Indonesia & 54 & Shorea negrosensis & Philippines \\
\hline 15 & Shorea chrysophylla & Indonesia & 55 & Shorea squamata & Philippines \\
\hline 16 & Shorea parvifolia & Indonesia & 56 & Shorea multiflora & Indonesia \\
\hline 17 & Shorea acuminata & Indonesia & 57 & Shorea mecystopteryx & Indonesia \\
\hline 18 & Shorea xantophylla & Indonesia & 58 & Shorea seminis & Indonesia \\
\hline 19 & Shorea acuminatissima & Indonesia & 59 & Shorea selanica & Indonesia \\
\hline 20 & Shorea andulensis & Indonesia & 60 & Shorea leptoclados & Indonesia \\
\hline 21 & Hopea bancana & Indonesia & 61 & Shorea dasyphylla & Indonesia \\
\hline 22 & Hopea sangal & Indonesia & 62 & Shorea blumuthensis & Indonesia \\
\hline 23 & Shorea ovalis & Indonesia & 63 & Shorea compressa & Indonesia \\
\hline 24 & Shorea virescens & Indonesia & 64 & Shorea polysperma & Indonesia \\
\hline 25 & Shorea materialis & Indonesia & 65 & Shorea pauciflora & Indonesia \\
\hline 26 & Shorea macroptera & Indonesia & 66 & Shorea atrynervosa & Indonesia \\
\hline 27 & Shorea leprosula & Indonesia & 67 & Shorea singkawang & Indonesia \\
\hline 28 & Shorea kuntsleri & Indonesia & 68 & Shorea hofeifolia & Indonesia \\
\hline 29 & Shorea mujongensis & Indonesia & 69 & Shorea eminiens & Indonesia \\
\hline 30 & Shorea laevis & Indonesia & 70 & Shorea beccariana & Indonesia \\
\hline 31 & Shorea smithiana & Indonesia & 71 & Shorea brachteolata & Indonesia \\
\hline 32 & Shorea teysmaniana & Indonesia & 72 & Shorea pauciflora & Indonesia \\
\hline 33 & Shorea sandakanensis & Indonesia & 73 & Shorea ochracea & Indonesia \\
\hline 34 & Hopea celebica & Indonesia & 74 & Shorea sumatrana & Indonesia \\
\hline 35 & Hopea grifithii & Indonesia & 75 & Upuna borneensis & Indonesia \\
\hline 36 & Hopea nigra & Indonesia & 76 & Monotes kerstingii & Africa \\
\hline 37 & Shorea balangeran & Indonesia & & & \\
\hline 38 & Shorea scaberrima & Indonesia & & & \\
\hline 39 & Shorea faguetiana & Indonesia & & & \\
\hline 40 & Parashorea lucida & Indonesia & & & \\
\hline
\end{tabular}




\subsection{Methods}

\subsubsection{Laboratory methods}

\subsubsection{DNA extraction}

The total genomic DNA was extracted from about $40 \mathrm{mg}$ of dried, healthy leaves using the DNeasy ${ }^{\circledR} 96$ Plant Kit (Qiaqen, Hilden, Germany), following the manufacturers protocol. The concentration and quality of the extracted DNA were checked by $0.8-1 \%$ agarose gel electrophoresis with a Lambda DNA size marker (Roche) (Sambrook et al., 1989), visualized by UV illumination using a polaroid camera after ethidium bromide staining.

\subsubsection{Polymerase Chain Reaction (PCR)}

Parts of four chloroplast regions were amplified by PCR using previously described primers (Table 3.2). All primers were recommended by different sources. The two recommended plastid regions from the CBOL Plant Working Group (2009), $r b c \mathrm{~L}$ and matK, were included.

Table 3.2 Primers used in the present study

\begin{tabular}{|c|c|c|c|c|}
\hline NO & Region & $\begin{array}{l}\text { Name of } \\
\text { primers }\end{array}$ & Sequence orientation $\left(5^{\prime} \rightarrow 3^{\prime}\right)$ & Reference \\
\hline \multirow{2}{*}{1} & \multirow{2}{*}{$\begin{array}{l}\text { pbsC- } \\
\text { trnS IGS }\end{array}$} & cp6F & GGTCGTGACCAAGAAACCAC & \multirow{2}{*}{ Tsumura et.al., 2011} \\
\hline & & cp6iR2 & CCCAGAACAAAATGAGAGGT & \\
\hline \multirow{2}{*}{2} & \multirow{2}{*}{$\begin{array}{l}\text { trnL } \\
\text { intron }\end{array}$} & $\mathrm{Cp} 2 \mathrm{~F}$ & CGA AAT CGG TAG ACG CTA CG & \multirow{2}{*}{ Taberlet et al.,1991 } \\
\hline & & $\mathrm{Cp} 2 \mathrm{R}$ & GGG GAT AGA GGG ACT TGA AC & \\
\hline \multirow{2}{*}{3} & \multirow{2}{*}{ matK } & $390 f$ & CGATCTATTCATTCAATATTTC & Cuenoud et al. 2002 \\
\hline & & 990R & GGACAATGATCCAATCAAGGC & Dayananda et al., 2006 \\
\hline \multirow{2}{*}{4} & \multirow{2}{*}{$r b c \mathrm{~L}$} & rbcLa_f & ATGTCACCACAAACAGAGACTAAAGC & Kress and Erickson., 2007 \\
\hline & & rbcLa_r2 & GAAACGGTCTCTCCAACGCAT & Fazekas et al., 2008 \\
\hline
\end{tabular}

The PCR was performed in a Peltier Thermal Cyler PTC-200 (MJ Research Inc.) with a volume of $15 \mu 1$ reaction mixture (Table 3.3). The PCR temperature profiles for the four chloroplast regions are shown in Table 3.4. 
Table 3.3 Reaction mixture of PCR reagents

\begin{tabular}{ll}
\hline Reagents & Volume $(15 \mu \mathrm{l})$ \\
\hline PCR buffer & $1,5 \mu 1$ \\
$\mathrm{MgCl}_{2}$ & $1,5 \mu \mathrm{l}$ \\
Forward Primer $(5 \mathrm{pmol} / \mu \mathrm{l})$ & $1 \mu \mathrm{l}$ \\
Reverse Primer $(5 \mathrm{pmol} / \mu \mathrm{l})$ & $1 \mu 1$ \\
$\mathrm{dNTPs}$ & $1 \mu \mathrm{l}$ \\
$\mathrm{Tag}$ & $0,2 \mu \mathrm{l}$ \\
$\mathrm{H}_{2} \mathrm{O}$ & $6.8 \mu \mathrm{l}$ \\
Template DNA $(5-10 \mathrm{ng})$ & $2 \mu 1(5-10 \mathrm{ng})$ \\
\hline
\end{tabular}

Table 3.4 Temperature profiles for PCR reactions

\begin{tabular}{|c|c|}
\hline Step & Condition \\
\hline Step 1: & Initial denaturation at $95^{\circ} \mathrm{C}$ for 15 minutes \\
\hline \multirow[t]{4}{*}{ Step 2: } & 35 cycles of \\
\hline & Denaturation at $94^{\circ} \mathrm{C}$ for 1 minute \\
\hline & Annealing at $50^{\circ} \mathrm{C}$ for 1 minute \\
\hline & Elongation at $72^{\circ} \mathrm{C}$ for $1: 30$ minutes \\
\hline Step 3: & Final extension at $72 \mathrm{C}$ for 20 minutes \\
\hline
\end{tabular}

To obtain purified DNA for sequencing, the DNA products were separated in agarose gels by electrophoresis. The DNA fragments in the agarose gel were sliced with a razor and then purified using the GENECLEAN® Kit (MP Biomedicals, Illkirch, France).

\subsubsection{Direct DNA sequencing}

The sequence data of the chloroplast DNA were obtained through direct sequencing. The sequencing reactions were performed using the ABI Prism ${ }^{T M}$ Big Dye ${ }^{T M}$ Terminator Cycle Sequencing Ready Reaction Kit v1.1 (Applied Biosystems), based on the principles described by Sanger et al. (Sanger et al., 1977). Data were collected from capillary electrophoresis on an ABI Prism 3100® Genetic Analyzer with the Sequence Analysis Software v3.1 (Applied Biosystems). The sequencing was performed with forward and reverse primers in both directions. The sequencing reaction mixture is shown in Table 3.5, while the temperature profiles of the PCR for sequencing are shown in Table 3. 6. 
Table 3.5 Reaction mix of PCR Sequencing reagents

\begin{tabular}{ll}
\hline Reagents & Volume $(10 \mu \mathrm{l})$ \\
\hline Big Dye & $1 \mu 1$ \\
$5 \mathrm{X}$ buffer & $1,5 \mu \mathrm{l}$ \\
Primer (F or R) & $1 \mu 1$ \\
$\mathrm{H}_{2} \mathrm{O}$ & $4.5 \mu 1$ \\
Template DNA & $2 \mu 1(5-10 \mathrm{ng})$ \\
\hline
\end{tabular}

Table 3.6 Temperature Profiles for Sequencing PCR reactions

\begin{tabular}{|c|c|}
\hline Step & Condition \\
\hline Step 1: & Initial denaturation at $96^{\circ} \mathrm{C}$ for 1 minutes \\
\hline Step 2: & 35 cycles of \\
\hline & Denaturation at $96^{\circ} \mathrm{C}$ for 10 second \\
\hline & Annealing at $45^{\circ} \mathrm{C}$ for 10 second \\
\hline & Elongation at $60^{\circ} \mathrm{C}$ for 4 minutes \\
\hline Step 3: & Final extension at $72 \mathrm{C}$ for 20 minutes \\
\hline
\end{tabular}

\subsubsection{DNA sequence analysis}

The sequences retrieved from the NCBI are a consensus sequence that has been assembled containing both forward and reverse strands. Meanwhile, for the sequences obtained from the laboratory, the CodonCode aligner version 3.7.1 (CodonCode Corporation) was used to edit and confirm the electropherograms of the sequences. The sequences data from the sequencer resulted in an Applied Biosystems (ABI) chromatogram file, which was then scored for quality assignments using the base calling program Phred (CodonCode Corporation). Phred reads DNA sequence chromatogram files and analyzes the peaks to call bases, assigning quality scores ("Phred scores") to each base call. Phred was also used for the assembly of consensus sequences for each sample from the replicate bidirectional sequence reads. The retrieved sequences can be found in the appendix 1 for the four chloroplast regions used in this research, $p s b \mathrm{C}$-trnS IGS, trnL intron, matK and $r b c \mathrm{~L}$ regions.

\subsubsection{Multiple sequence alignment}

The chloroplast sequences were aligned using the Clusthal W (Thompson et al., 1994) multiple sequence alignment program, found in Bioedit version 7.0.9. (Hall, 1999). The alignment results were corrected manually. The alignment data of those four regions then 
transfered to DNASP v.5.10.01 software in order to get the information about sequence characteristics.

\subsubsection{Phylogenetic analysis}

Phylogenetic analyses of Dipterocarpaceae based on four chloroplast regions were carried out using parsimony and maximum likelihood analysis with MEGA 5 (Tamura et al., 2011). The tree topology was formed using MEGA 5 and the trees were rooted with an outgroup. Poor PCR product quality prevented the same chosen outgroup species from being used for all four chloroplast regions, possibly because the primers were not suitable for each outgroup species. For the trnL intron, we used Monetes kerstingii from Benin (subfamily Monotoideae) as an out-group, for psbC-trnS IGS Upuna borneensis (tribe Dipterocarpoideae), for matK Monotes madagascariensis (subfamily Monotoideae) and for $r b c \mathrm{~L}$ Monotes kerstingii (subfamily Monotoideae).

\subsubsection{Taxonomic identification key based on phylogenetic tree}

One of the aims of this study is to develop a molecular taxonomic identification key. A molecular identification key was developed based on the clades formed in the phylogeny analysis using maximum parsimony method. The tree is shown in Appendix 12. The plastid region trnL intron was chosen as a model for the key because this gene region has the most sequence data available in the NCBI database for the members of subfamily Dipterocarpoideae. The tool is similar to a dichotomous key that uses morphological characters, except that in this study DNA sequences from chloroplast regions were used instead of the morphological characters.

The arrangements of the characters were based on the topology of the phylogenetic trees that formed from the parsimony analysis. The cladogram produced by the phylogenetic analysis then classify based on the clades. According to (McLennan, 2010), a clade is a group of organisms that includes an ancestor and all descendents of that ancestor. Clades are nested within one another and they form a nested hierarchy within a phylogenetic tree. Since every clade share homologous sequences (Chao and Zhang, 2009), the species belong to one clade 
should be closely related. However, even though they are closely related, there should be distinct characters that make them separated into different branches.

The following steps describe the construction of the dichotomous key based on the DNA sequences.

Step 1. The key was split based on the clades that were formed by the cladogram produced by the phylogenetic analysis.

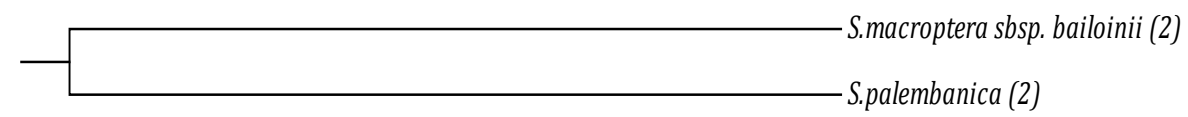

Step 2. Using multiple alignments in Clusthal W (Thompson, 1994) the polymorphisms among the monophyletic groups of each clade were characterized.

Step 3. Polymorphic sites were summarized in a table (see table 3.7 as an example).

Table 3.7 Table for polymorphic sites of the species and their nucleotides.

\begin{tabular}{|c|c|c|c|c|}
\hline \multirow{2}{*}{ Species } & \multicolumn{4}{|c|}{ Polymorphic site } \\
\cline { 2 - 5 } & 244 & 246 & 275 & 276 \\
\hline S. macrotera sbsp.bailonii & - & G & A & C \\
\hline S. palembanica & A & A & C & T \\
\hline
\end{tabular}

Step 4. The key was constructed based on the polymorphic sites and bases.

1 a. site 244 is $(-) \ldots \ldots \ldots \ldots \ldots \ldots \ldots \ldots \ldots \ldots$

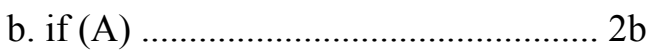

2. a. site 246 is $(\mathrm{G}) \ldots \ldots \ldots \ldots \ldots \ldots \ldots \ldots$

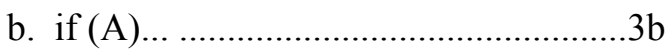

3. a. site 275 is (A) ..................... 4a

b. if $(\mathrm{C})$

4. a. site 276 is $(\mathrm{T})$......................... S. palembanica

b. If (C) …………………………........... macroptera sbsp bailonii 


\subsubsection{Barcode analysis}

We used two barcode regions, matK and $r b c L$, which were adopted from the Consortium for the barcode of life (CBOL plant working group 2009) to assess the suitability of these two gene regions to discriminate Dipterocapaceae species. To support the barcode analysis, we performed the phylogenetic analysis based on distance algorithm methods. The query sequences from the laboratory (marked with $\mathrm{X}$ ) were combined with the sequences retreived from the NCBI database and analyzed using the K2P distance NJ method with MEGA 5 (Kimura, 1980 ; Tamura et al., 2011). The neighbor joining method, which is embedded in MEGA 5, was the chosen as method to construct the phylogenetic trees for the barcode analysis, with the following settings: Kimura's 2 parameter was the chosen model/method. Beside the neighbor joining analysis, we also executed the nBLAST identification from the NCBI website. The purpose of this analysis was to evaluate the reliability of the nBLAST tool as a taxonomic identification method using sequence data because this tool was lately used worldwide as a routine and quick identification system (Kool et al., 2012; Mount, 2007a; Pons, 2006). The known samples from the own laboratory analyses were used as queries in the nBLAST. 


\section{Results}

\subsection{DNA sequence characteristics}

The numbers of successfully sequenced Dipterocarp samples were not the same for the studied regions, because not all of the four primers used work well with Dipterocarpaceae. Of the four primers sequenced, the trnL intron and $r b c \mathrm{~L}$ had a $94 \%$ sequencing success rate, while the matK region and psbC-trnS IGS had success rates of $70 \%$ and $76 \%$, respectively (Table 4.1).

The highest numbers of taxa available from the NCBI (Appendix 1) belong to the psbC-trnS IGS region (210 sequences). Conversely, there are very few $r b c \mathrm{~L}$ region sequences from Dipterocarp species deposited in the NCBI ( 5 sequences). Of all four primers, the trnL intron has the highest combined number of species (145, both deposited in the NCBI and the Forest Genetics and Forest Tree Breeding Institute laboratory) from different genera and tribes, whereas $r b c \mathrm{~L}$ has the lowest number (67 species). The matK gene and psbC-trnS IGS had 116 and 117 species, respectively (Table 4.1).

Table 4.1 The sequence information of four chloroplast regions

\begin{tabular}{|c|c|c|c|c|}
\hline Parameter & $r b c \mathrm{~L}$ & matK & $p s b C$-trnS IGS & trnL intron \\
\hline Number of Sequences from NCBI & 5 & 109 & 210 & 191 \\
\hline Number of additional sequences & 71 & 53 & 56 & 143 \\
\hline Sequencing success & $93 \%$ & $70 \%$ & $75 \%$ & $93 \%$ \\
\hline Number of species & 67 & 116 & 117 & 145 \\
\hline Aligned length & $647 \mathrm{bp}$ & $635 \mathrm{bp}$ & $1136 \mathrm{bp}$ & $537 \mathrm{bp}$ \\
\hline
\end{tabular}

The length of the obtained sequences varied, but the final alignment lengths ranged from 537 bp for the trnL intron to 1136 bp for the psbC-trnS IGS (Table 4.1).

\subsection{1 psbC- trnS IGS region}

The amplification and sequencing results using the primer of this region was only moderately successful; only 57 species from 76 leaf samples (75\%) from the additional data samples were successfully sequenced. Combining these results with the available data in the NCBI database, which totaled 210 sequences, resulted in a total of 118 species restricted to tribe 
Shoreae. The final lengths of the sequences after being aligned and manually edited were 1136 bp (Table 4.1).

\subsection{2 trnL intron region}

Amplification using this region was mostly successful for the additional leaf samples. From 76 samples, we were able to amplify and sequence 71 samples (93\%). The individual sequences' length was around $570 \mathrm{bp}$. The combination of 191 DNA sequences from the NCBI - 71 sequences from the leaf sample collection and 72 from Rachmayanti (2009), from whom the samples were obtained personally, and Nguyen (2009) yielded the highest number of sequences among the chloroplast regions that were used in this study; a total of 334 trnL intron sequences representing 145 species from subfamily Dipterocarpoideae. The final length of the refined sequences that will be used for further analysis was $537 \mathrm{bp}$ (Table 4.1).

Table 4.2 Sequence characteristics of four chloroplast regions

\begin{tabular}{|c|c|c|c|c|}
\hline Parameter & $\boldsymbol{r b c L}$ & matK & $\boldsymbol{p s b C - t r n S - I G S}$ & trnL intron \\
\hline Number of nucleotides & $647 \mathrm{bp}$ & $635 \mathrm{bp}$ & $1136 \mathrm{bp}$ & $537 \mathrm{bp}$ \\
\hline Number of variable sites & 47 & 309 & 117 & 112 \\
\hline $\begin{array}{c}\text { Number of informative } \\
\text { characters }\end{array}$ & 45 & 234 & 110 & 103 \\
\hline Number of haplotypes & 27 & 81 & 70 & 61 \\
\hline Haplotype diversity (Hd) & 0.875 & 0.950 & 0.825 & 0.850 \\
\hline G+C content & 0.431 & 0.329 & 0.433 & 0.320 \\
\hline
\end{tabular}

\subsection{3 matK region}

This region produced the lowest, albeit moderately, successful sequencing results; ' $70 \%$ of the samples (53 of 76) were successfully sequenced. The final lengths after alignment and manual refinement were $635 \mathrm{bp}$. The total matK sequences comprised both tribes Shoreae and Dipterocarpeae. Among the four chloroplast regions, this gene region gave the highest 
number of informative characters (234) as well as number of variable sites (309) (Table 4.2). The number of haplotypes in this region was also the highest (81).

\subsection{4 $r b c L$ region}

The amplification of the $r b c \mathrm{~L}$ region was mostly successful for Dipterocarpaceae species, particularly those in Shoreae. From a total 76 species sequenced, only 5 species could not be amplified using this region (93\% success rate). Using the $r b c \mathrm{~L}$ region to obtain both successful PCR products and sequencing results was easy. Combining these results with the 5 $r b c \mathrm{~L}$ sequences downloaded from the NCBI resulted in a total of 69 different species. The final lengths of the sequences after alignment and manual correction were $647 \mathrm{bp}$. The $r b c \mathrm{~L}$ gene region has 47 variable sites and 45 informative characters (Table 4.2).

\subsection{Molecular phylogeny based on four chloroplast regions}

The analyses of the four chloroplast regions using three statistical methods (maximum parsimony, maximum likelihood and neighbor joining) yielded a total of 12 phylogenetic trees. Using U. borneensis, M. madagascariensis and M. kerstingii as an outgoup, the common topologies of the trees showed similar, though not exactly identical patterns. As the three phylogenetic analysis methods resulted in similar patterns, only the most interesting result will be described.

\subsection{1 psbC-trnS IGS region}

The maximum parsimony tree of the psbC-trnS IGS is shown in Fig. 4.1. Using $U$. borneensis as an outgroup; this gene was able to resolve tribe Shoreae into two clades with a strong bootstrap value of $98 \%$. Some of those clades formed subclades with paraphyletic groups based on the section. This clade comprises a mix of some sections of the Shorea group, sister with Parashorea, and formed a sister subclade with Hopea with a strong bootstrap value (100\%). The Shorea group of the subclade comprises section Brachyptera (S. almon, S. platyclados, S. pachycarpae, S. kuntsleri, S. scaberrima, S. pauciflora, S. 
johorensis, S. andulensis, S. smithiana, S. pubistylla, S. bullata), section Mutica (S. curtisii, S. macroptera subsp. sandakanensis, S. macroptera subsp. macropterifolia, S. parvifolia, S. ovata, S. ferruginea, S. quadrinervis, S. teysmaniana, S. rugosa, S. platycarpa, S. acuta, S. macroptera, S. rubra, S. slootenii, S. leprosula, S. dasyphylla, S. argentifolia), one member of section Ovalis (S. ovalis), section Pachycarpae (S. amplexicaulis, S. pilosa, S. splendida, S. beccariana, S. mecystopteryx, S. stenoptera, S. macrophylla) and one member of section Rubella (S. albida). This subclade branch also comprises three Hopea lineages from section Dryobalanoides (H. grifithii, H. nigra) and section Hopea (H. celebica) (Fig. 4.1a). Another clade formed a monophyletic group of section Anthoshorea that excluded S. obscura, which belongs to section Shorea. (Fig. 4.1b). Fig. 4.1c shows lineage from section Richetioides. Fig. 4.2.1d shows a paraphyletic clade that mostly dominated with section Shorea (S. biawak, $S$. maxwelliana, S. laevis, S. falciferoides, S. havilandii, S. foxworthyi, S. guiso, S. seminis, S. superba, S. crassa, S. materialis, S. domatiosa, S. inappendiculata, S. atrinervosa), section Neohopea (S. isoptera), section Richetioides (S.blumuthensis and S. polysperma). The results in Fig. 4.1e show the paraphyletic group that comprises a Hopea group from section Dryobalanoides (H. dryopbalanoides, H. mengarawan) and section Hopea (H. bancana, $H$. odorata, H. sangal), sister subclade with $N$. hemii, which is clustered together with $S$. astylosa.

The phylogenetic tree based on maximum likelihood methods of this region (Appendix 4) did not show a great ability to resolve tribe Shoreae. This method resolve one big paraphyletic clade from other member of tribe Dipterocarpeae with high bootstrap support (97\%).

This paraphyletic clade comprises species from Shorea, Hopea, Neobalanocarpus and Parashorea genera in one group that is separated from other members of the Dipterocarpeae tribe, specifically Anisoptera laevis, Cotylelobium lanceolatum, Vatica bella and Vatica oblongifolia, that formed a sister clade with Upuna borneensis as a single outgroup. 


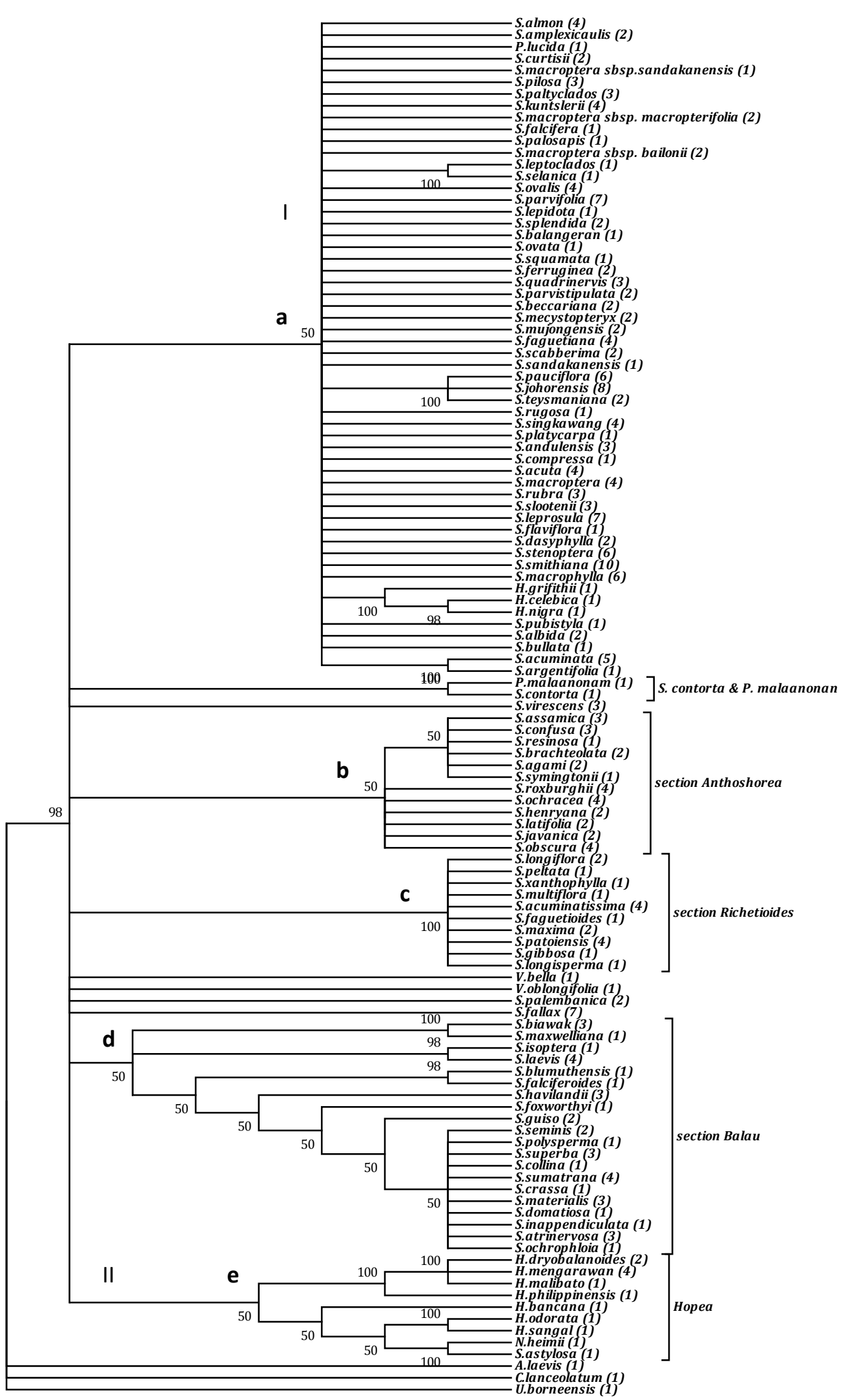

Fig 4.1 The tree of the psbC-trnS region using maximum parsimony method. (a) Is the paraphyletic clade consist the member of Shorea, Hopea and Parashorea. (b) Is a subclade section Anthoshorea that excluded S. obscura (c) is lineage from section Richetioides. (d) is section Shorea that excluded S. isoptera from section Neohopea, and S. blumuthensis and S. polysperma from section Richetioides. (E) is paraphyletic group that comprises a Hopea sister subclade with N. hemii and $S$. astylosa. 
The neighbor joining tree of this region that utilized $U$. borneensis as an outgroup, could separate Cotylelobium as a sister subclade. This method was also able to separate tribe Shoreae from members of tribe Dipterocarpeae (specifically, V. bella and V. oblongifolia) with high bootstrap value (100\%). Compared with the ML tree, this method was able to form a monophyletic group for subclade Richetioides and Anthoshorea, with bootstrap values of 62 $\%$ and $80 \%$, respectively. This tree was able to resolve C. lanceolatum from other species with a bootstrap value of $61 \%$, and $A$. laevis from other species with a bootstrap value of $67 \%$. This method formed a paralyphyletic clade that comprised several subclades from sections Shorea, Richetioides and Anthoshorea. Those subclades formed polytomies with the Red Meranti group of Shorea (Appendix 5).

\subsection{2 trnL intron region}

The topology of the tree construction using maximum parsimony, maximum likelihood and neighbor joining, were similar for the trnL intron region (Fig 4.2 and Appendices 2 and 3). The three methods were able to separate the Dipterocarpeae group $(X=11)$ from the Shoreae group $(X=7)$ with bootstrap values between $87 \%$ and $99 \%$. However, the cladogram shows that the trees yielded many polytomies.

Using maximum parsimony (Fig. 4.2), the trnL intron gene was not able to resolve the Dipterocarpoideae very well. The tree topology showed that the gene could not resolve most of the members of Dipterocarpoideae, with low bootstrap support (12\%) (data not shown). This gene could only resolve the Dipterocarpus group (tribe Dipterocarpeae) from the members of tribe Shoreae. Additionally, this gene could not resolve other genera from Dipterocarpeae, specifically Vatica, Anisoptera and Upuna.

The results showed many polytomies in one clade, but the subclade showed that the trnL intron gene was able to resolve the Dipterocarpus group from other sister branches, with a high bootstrap value (99\%). A monophyletic group was also formed for members of 


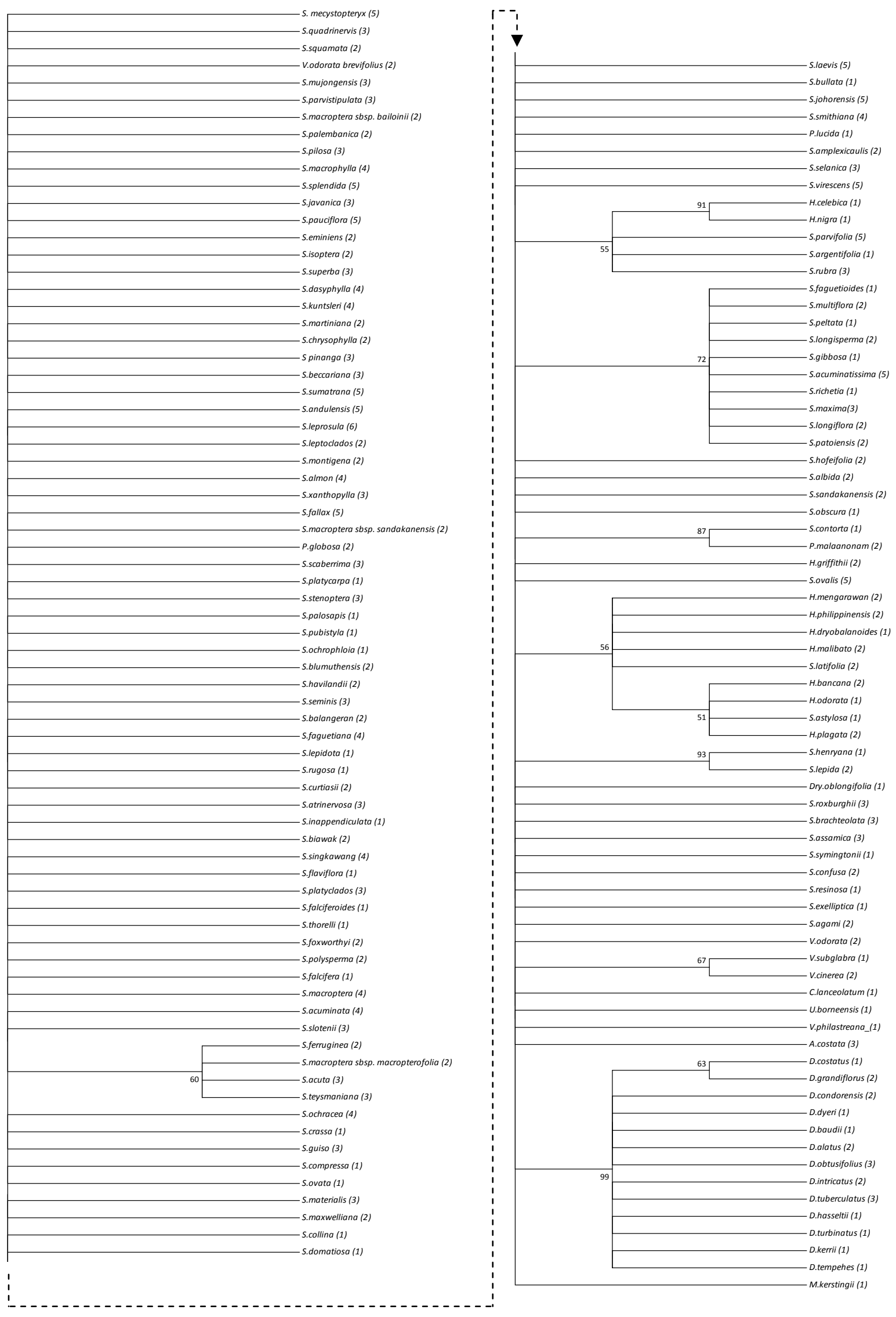

Fig 4.2 The tree of trnL intron using maximum parsimony method. Branches corresponding to partitions reproduced in less than $50 \%$ bootstrap replicates are collapsed. The number in parentheses means number of species tested. 
Richetioides (S. faguetioides, S. multiflora, S. longisperma, S. peltata, S. gibbosa, S. acuminatissima, S. richetia, S. maxima, S. longiflora, S. patoiensis).

This region could not resolve the Hopea genera as a single monophyletic group. The Hopea genera were still nested with some of Shorea species (S. astylosa, and S. latifolia) with a bootstrap value of $56 \%$. Meanwhile other member of Hopea (H. celebica and H. nigra) formed sister branch with member of Shorea (S. parvifolia, S. argentifolia, S. rubra). (Fig. $4.2)$.

When using the maximum likelihood method for the trnL intron gene, two groups were formed (Appendix 2). One group consisted of members of the genus Dipterocarpus, with high bootstrap support (99\%), and the other was a mixed group of tribe Shoreae. However, other members of the Dipterocarpeae tribe (Cotylelobium, Anisoptera, Upuna and Vatica) formed a subclade in this group with high bootstrap support (92\%). This method was also able to resolve some sections of tribe Shoreae in the subclade; for example, section Richetioides with a bootstrap value of $91 \%$, and section Anthoshorea as well as parts of section Mutica, with bootstrap values of $62 \%$ and $52 \%$, respectively. Some Hopea genera formed a group but were still nested with one species of section Shorea (S. astylosa), while others formed polytomies among the Shorea species. The trnL intron gene could not group two species of Parashorea into a single group. P. malaanonan was grouped together with $S$. contorta, while P. lucida was nested with other polytomies of Shorea.

The neighbor joining method showed similar patterns as the maximum likelihood method (Appendix 3). This method was also unable to resolve members of the Dipterocarpoideae, although some of the genera were grouped within a single subclade. The subclade of Dipterocarpus showed one group with high bootstrap support (99\%). Other Dipterocarpeae members formed another group, also with a high bootstrap value (88\%).

A subclade of Richetioides formed one monophyletic group, with a high bootstrap value (92\%), while a part of section Anthoshorea, as well as part of section Mutica, which formed a monophyletic group with a bootstrap value of $64 \%$ for Anthoshorea and $62 \%$ for Mutica. The Hopea genera did not form one monophyletic group, instead remaining nested with some Shorea species. In this tree, some Hopea genera formed a paraphyletic group. There were three sister branches among a subclade of Hopea. One branch belonged to S. guiso, one to genus Hopea from section Hopea (H. plagata, H. bancana, H. odorata), which is nested with S. astylosa, and another branch belonged to $H$. mengarawan from section Hopea and $H$. dryobalanoides from section Dryobalanops, itself nested with S. latifolia. The neighbor 
joining method also produced the same results as the maximum likelihood method for the genus Parashorea, the subclade showing that $P$. malaanonan was grouped together with $S$. contorta, while P. lucida was nested with other polytomies of Shorea.

\subsection{3 matK region}

The tree topology using M. madagascariensis as an outgroup showed that all three statistical methods (MP, ML and NJ) were unable to resolve Diptercarpoidae well. However, all three statistical methods succeeded in using the matK gene region to resolve section Doona of Shorea group. The section Doona (S. affinis, S. zeylanica, S. cordifolia, S. gardneri, S. worthingtonii, S. trapezifolia, S. congestiflora, S. disticha, S. megistophylla) maintained a stable monophyletic group with strong bootstrap support $(<91)$, while other sections of both tribes formed paraphyletic groups (Fig. 4.3 Appendix , 6 and 7). The topology of the trees did not show a significant difference. All the trees were able to resolve Dipterocarpus as one monophyletic group which formed a sister subclade with the other subclades.

For the maximum parsimony tree, the first subclade, shown in Fig 4.3, was a paraphyletic group, with only moderate bootstrap support (52\%). This subclade comprised numerous members of tribe Shoreae (sections Brachyptarae, Mutica, Richetioides, Ovalis and Pachycarpae).

The second subclade belongs to two members of Parashorea (P. chinensis and P.chinensis var. kwangsiensis) in one group supported with a moderately high bootstrap value (63\%). This subclades formed a sister branch with other Parashorea members; P.lucida which is nested in the Shorea sub clade, and formed a sister branch with P.malaanonan. The tree topology obtained using MP and NJ methods were similar.

The Neobalanocarpus genus formed its own sister branch with the Hopea (H. sangal, $H$. bancana, $H$. helferi, $H$. jucunda, $H$. subalata, $H$. discolor, $H$. nervosa, $H$. latifolia, $H$. jucunda subsp. modesta, H. malibato, H. mengarawan, $H$. dryobalanoides, $H$. philippinensis, H. odorata, H. wightiana, H. plagata) and Shorea (S. brachteolata, S. virescens, S. lepida, 


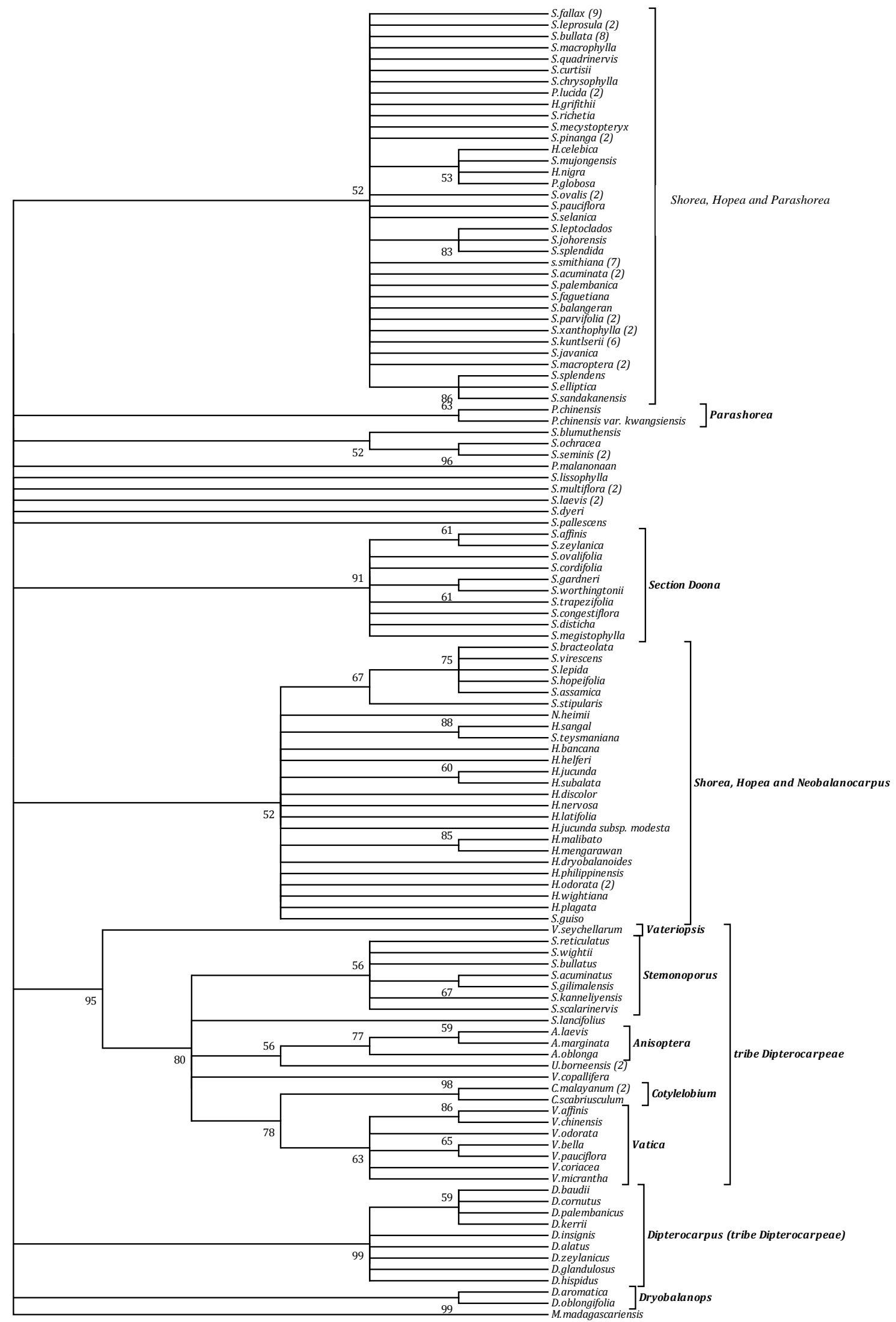

Fig 4.3 The tree of matK region using the maximum parsimony method. The percentage of bootstrap support shown next to the branch. Tree type 1 out of 136 most parsimonious trees shown. consistency index is $(0.650246)$, the retention index is $(0.924708)$, and the composite index is 0.755496 . The number in parentheses means number of species tested 
S. hopeifolia, S. assamica, S. stipularis, S. guiso, S. teysmaniana) groups, with a bootstrap value of $52 \%$.

Using maximum parsimony (Fig 4.3), a subclade of tribe Dipterocarpeae member (excluded Dipterocarpus) showed a paraphyletic group. In this clade, Stemonoporus species allied with member of Vatica, Anisoptera, Upuna and Cotylelobium with strong bootstrap support $(95 \%)$.

The Dipterocarpus genus was resolved into a monophyletic group, comprised D. baudii, D. cornutus, D. palembanicus, D. kerii, D. insignis, D. alatus, D. zeylanicus and D. glandulosus, supported by a bootstrap value of $99 \%$.

The Dryobalanops genus was formed a monophyletic group comprised $D$. aromatica and $D$. oblongifoliasupported with a bootstrap value of $99 \%$.

The maximum likelihood method resulted in a tree similar to that of the maximum parsimony method (Appendix 6). This tree showed that several subclades composed of paraphyletic groups were formed, excluding section Doona, which formed a monophyletic group, with a high bootstrap value (93\%). Neobalanocarpus hemii, whose place in the family is still debated, is placed on the sister branch with the Hopea group in this tree with a bootstrap value of $66 \%$. Shorea guiso was nested with the Hopea group.

This maximum likelihood method also formed a paraphyletic group in one subclade of tribe Dipterocarpeae. In this subclade, Vatica seychellarum formed a sister branch with another subclade supported with a high bootstrap value (97\%). The subclade consisted of members of the genus Stemonoporus (Stemonoporus acuminatus, Stemonoporus gilimalensis, Stemonoporus wightii, Stemonoporus scalarinervis, Stemonoporus reticulatus, Stemonoporus kanneliyensis, Stemonoporus bullatus), U. borneensis, which formed a sister branch with members of Anisoptera (A. laevis, A. marginata, A. oblongata), and C. malayanum and C. scabriusculum, which formed a sister branch with some Vatica members (V. afinis, V. pauciflora, V. bella, V. odorata, V. coriacea, V. micrantha).

An analysis based on the neighbor joining method of the matK region showed a separation of the subclades, concurring with the results of maximum parsimony and maximum likelihood. A subclade formed a paraphyletic group with a bootstrap value of 53\%. The first branch of this subclade belonged to $H$. sangal and $S$. teysmaniana supported with a high bootstrap value (96\%); the second to the Shorea group (S. assamica, S.virescens, S. brachteolata, 
S.hopeifolia, S. stipularis), supported by a value of $75 \%$, and the third branch belonged to Neobalanocarpus, which was sister branch with the Hopea group (Appendix 7).

The Dryobalanops group was separated into a monophyletic group; D. aromatica and D. oblongifolia in one subclade with a high bootstrap value (99\%) and formed sister branch with other subclades.

The member of genus Dipterocarpus showed a monophyletic group subclade comprising $D$. insignis, D. zeylanicus, D. hispidus, D. glandulosus, D. alatus, D. cornutus, D. palembanicus, D. baudi and D. kerii, with a high bootstrap support (99\%). Other member of the Dipterocarpeae groups (Vatica, Anisoptera, Upuna, Cotylelobium) showed a similar topology as the one produced by the maximum likelihood method.

\subsection{4 $r b c L$ region}

Using maximum parsimony and $M$. kerstingii as an outgroup; this gene region was able to resolve tribe Dipterocarpeae from tribe Shoreae, with a bootstrap value of $64 \%$. However, the resolutions within the member of the tribe were not clear (Fig. 4.4). The members of the Shorea genus were still allied with Hopea and Parashorea genera. Our result showed that Parashorea malaanonan was grouped together with $S$. contorta, with a high bootstrap value $(98 \%)$.

The evolutionary history was inferred using the maximum likelihood method. This method could resolve the Dipterocarpeae tribe from tribe Shoreae. The $r b c \mathrm{~L}$ region was able to separate some members of Shorea, Hopea, and Parashorea, as well as members of Dipterocarpeae (U. borneensis, A. marginata, V. machapagoi) from other members of tribe Shoreae (Shorea, Hopea and Parashorea), with a low bootstrap value of 51\% (Appendix 8). Using neighbor joining to infer the evolutionary relationship of Diperocarpoideae members produced the same results as the maximum parsimony and maximum likelihood methods. The neighbor joining method was also unable to resolve members of tribe Dipterocarpeae from members of tribe Shoreae (Appendix 9). 


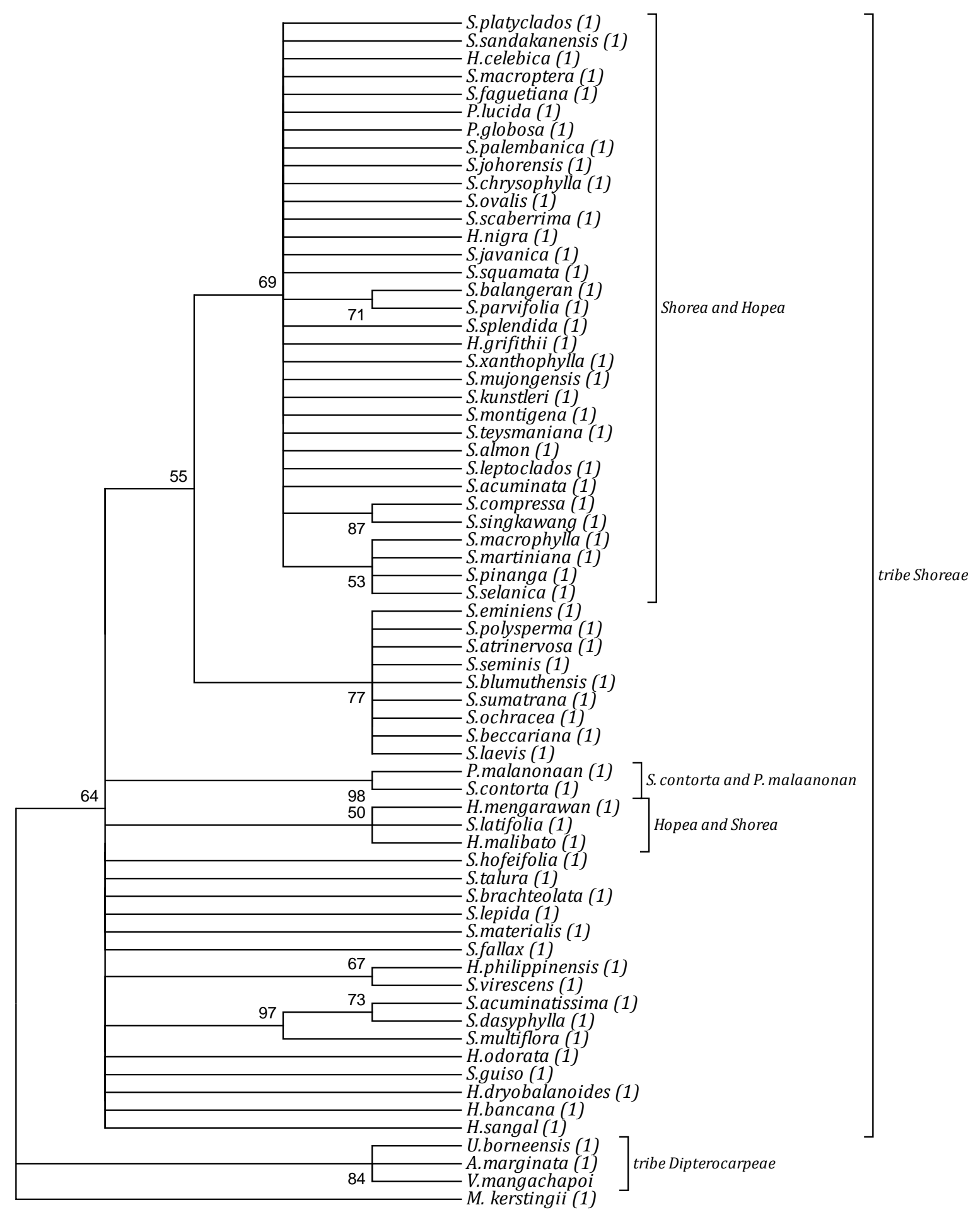

Fig 4.4 The tree of $r b c \mathrm{~L}$ gene using the maximum parsimony method. The percentage of bootstrap support shown next to the branch. Tree type 1 out of 428 most parsimonious trees (length $=147$ ) is shown. The number in parentheses mean number of species tested. 


\subsubsection{Combination dataset of psbC-trnS IGS, trnL intron, matK and $r b c L$}

There were only 40 species with the same gene regions available for the phylogenetic analysis; the combined total length of all four gene regions was $2098 \mathrm{bp}$. The combined data comprises species from Shorea, Parashorea and Hopea. The strict consensus tree for the maximum likelihood, maximum parsimony and neighbor joining methods are shown in Fig. 4.5. All trees showed congruent patterns, only the neighbor joining tree showed a slight difference with regard to the number of Shorea members including in the second clade. The trees separated the species into two paraphyletic clades containing a mixture of Shorea, Hopea and Parashorea. The first clade was dominated by Shorea genera, with three genera belonging to Hopea (H. celebica, H. nigra and H. grifithii) and two to Parashorea (P. lucida and P. malaanonan). The second clade was dominated by members of Hopea (H.odorata, H.bancana, H.philippinensis, H. dryobalanoides, $H$. malibato, $H$, mengarawan), with Shorea making up the rest (S. brachteolata, S. virescens, S. fallax, S. guiso, S. acuminatissima, S.multiflora).

The topology patterns of the subclades were stable for all three statistical methods, with the exception of a small number of clades that differed slightly (Fig.4.5). There were 11 subclades, of which 10 had the same group pattern, for all three methods; they are labeled by Roman numbers (I-XI) 


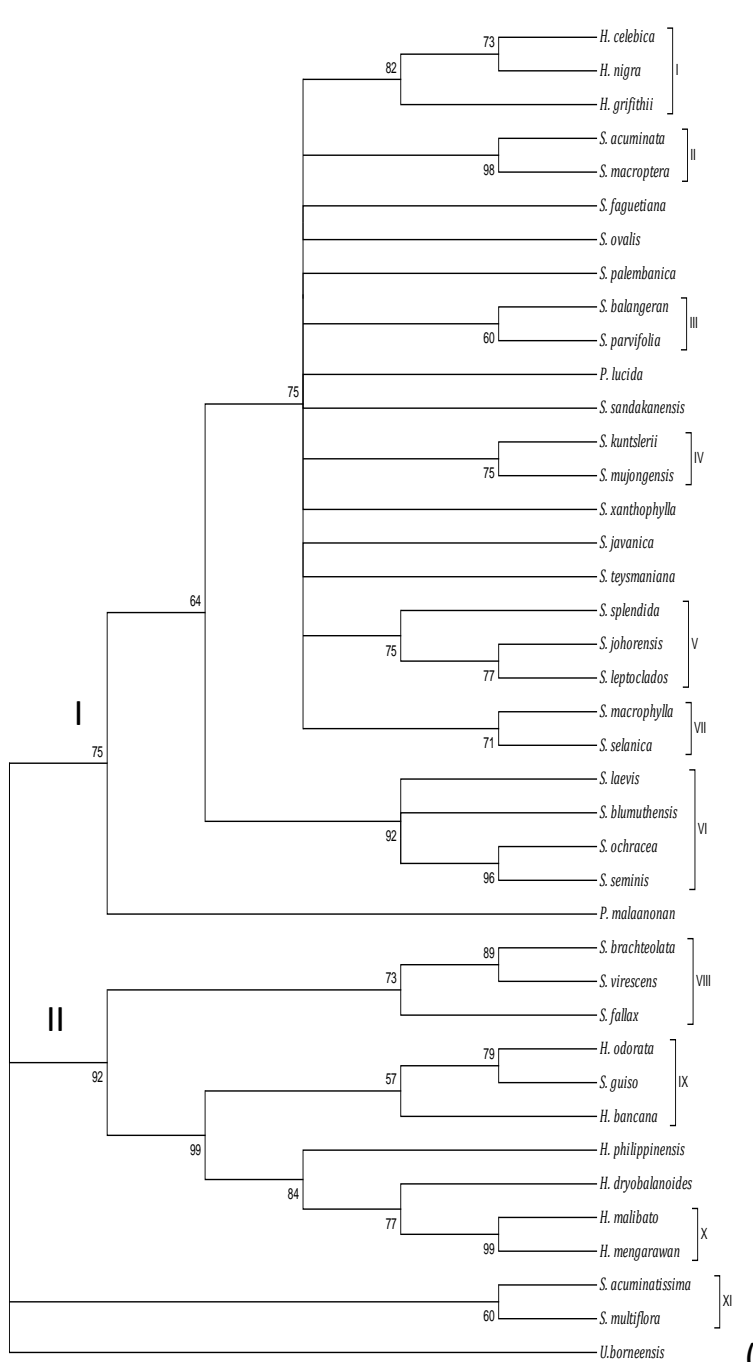

(A)

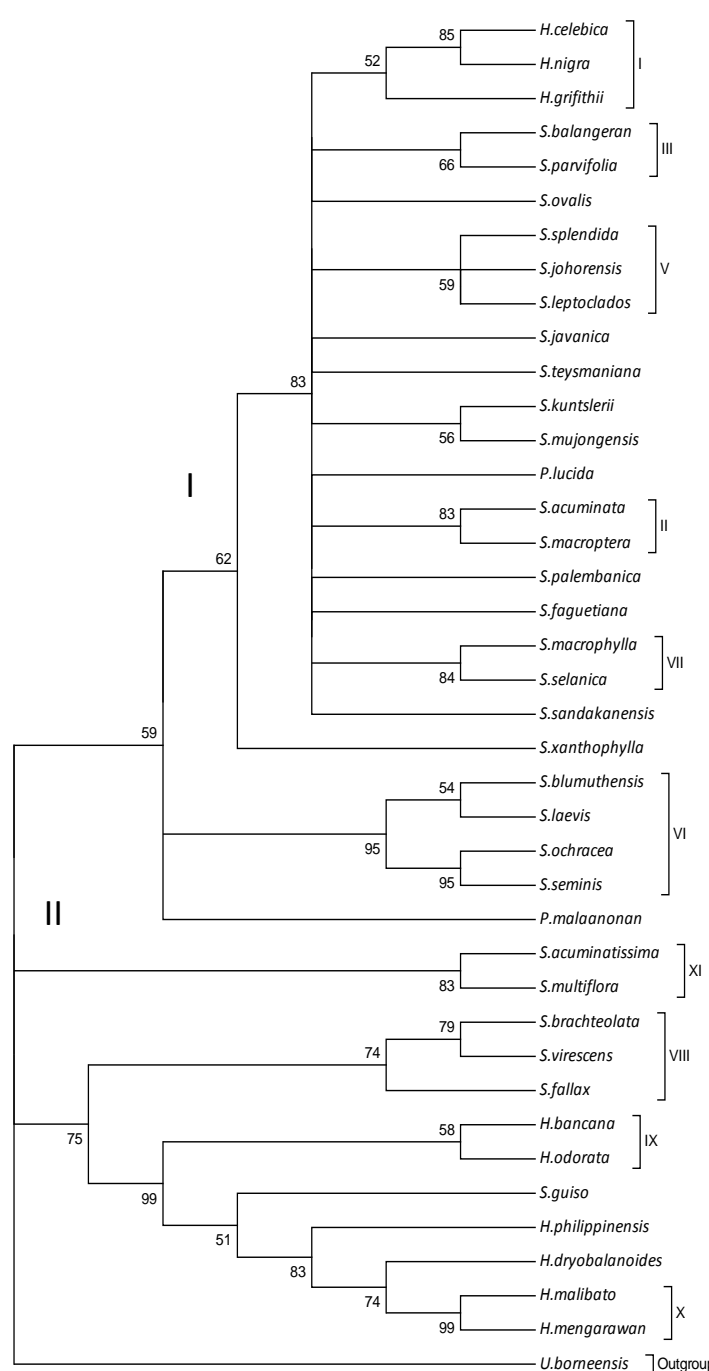

(B)

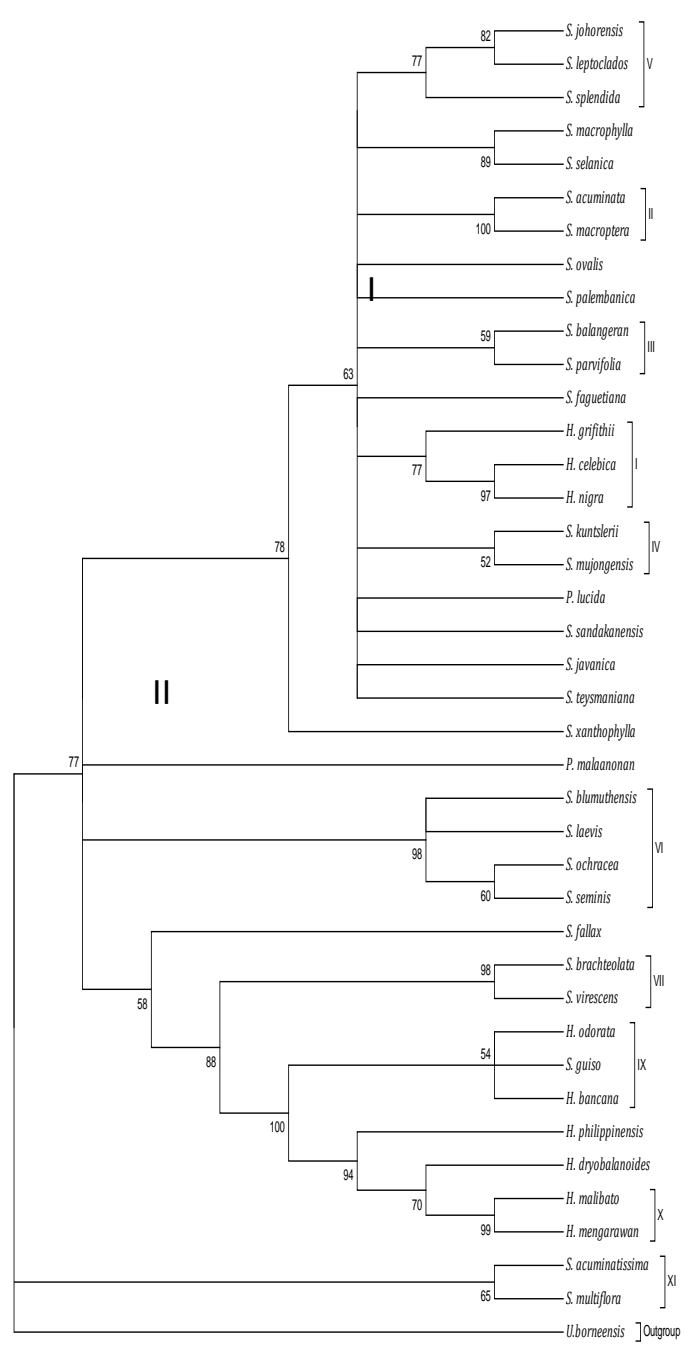

(C)

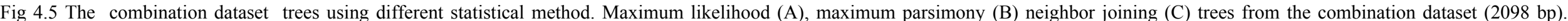
Numbers above the nodes denote bootstrap support based on 1000 bootstrap replicates. 


\subsection{The barcode analysis for matK and $r b c L$ region}

Both DNA regions were successfully utilized in obtaining Dipterocarpaceae data sequences. Within the Dipterocarpoideae tribe, 119 and 67 sequences were available for the matK and $r b c \mathrm{~L}$ regions, respectively. The neighbor joining trees for the different regions revealed both regions' abilities to distinguish tribe Dipterocarpeae with high bootstrap support. The matK region showed a potential discriminatory power to distinguish genera and species within tribe Shoreae (Appendix 10), while $r b c \mathrm{~L}$ could not resolve the genera of the tribe (Appendix 11). In our study, most of the matK sequences analyzed in our laboratory (marked with X) allied with the corresponding sequences from the same species available in the NCBI database (appendix 10).

The combination of matK and $r b c \mathrm{~L}$ was not able to resolve the Shorea, Hopea and Parashorea genera (Fig. 4.6). Using U. borneensis as an outgroup, the gene region combination was able to separate the 40 species into two paraphyletic clades with strong bootstrap support (98\%). The first clade was dominated by Shorea members, whereas the second clade was dominated by Hopea members. 


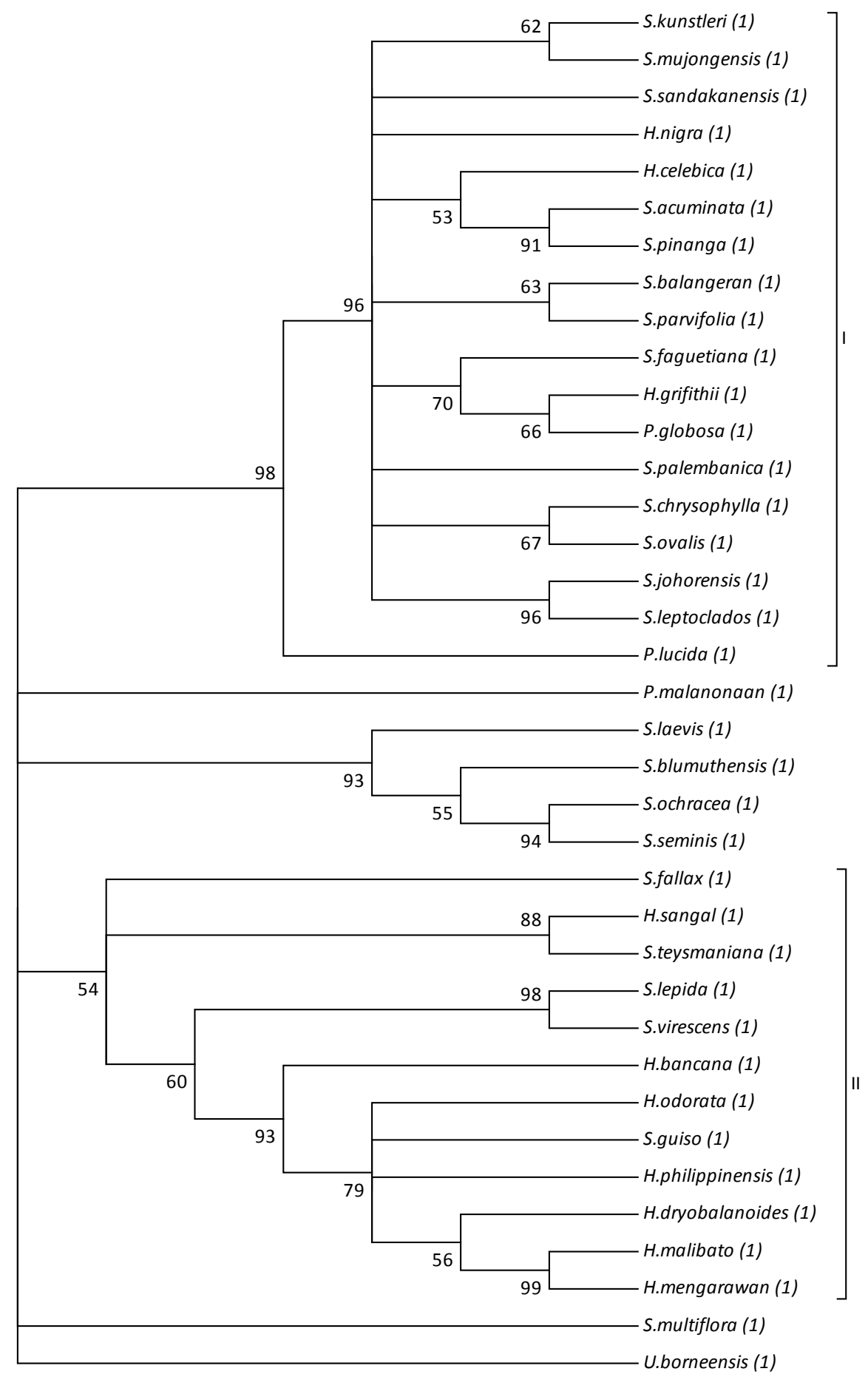

Fig 4.6 The neighbor joining tree of combined dataset matK and $r b c \mathrm{~L}$ (1282 nucleotides) using Kimura2 Parameter distance method. The number next to the branch is the bootstrap support test (1000 replicates). The tree was analyzed using MEGA 5.

The results of the nBLAST identification showed that of the 44 query sequences, 37 (84\%) were successfully assigned to the correct genus. Regarding the individual species, however, nBLAST was rarely successful in finding the best match. This is likely due to the lower number of the corresponding species in the NCBI. In addition, almost all of the tested 
sequences showed a low E-value (0.0). Only the best hits for $H$. sanggal showed an E-value higher than 0.0 (Table 4.3).

Some of the query sequences (seven out of 44) were matched with highly similar species from different genera. For instance, H. celebica, H. nigra, H. grifithii and P. globosa were all matched with with S. smithiana with $100 \%$ coverage and similarity. In addition, P. lucida was matched with S. smithiana with $100 \%$ coverage and $99 \%$ similarity, respectively. $S$. guiso was matched with $H$. wightiana with $100 \%$ coverage and $99 \%$ similarity, and $P$. malaanonan was matched with S. palescence with $100 \%$ coverage and $99 \%$ similarity (Table 4.3).

Some of the best Megablast hits led to the same species showing unique results; for example, S. ovalis, S. leprosula and S. acuminata revealed a higher similarity to S. smithiana than to themselves, despite the coverage being $100 \%$ and similarity $100 \%$ or $99 \%$. However, these species appeared at ranks lower than S. smithiana in the significant alignments'table (nBLAST result table). Shorea smithiana itself was matched with itself, although with a maximum identity of only $96 \%$. 
Table 4.3 The best match hits of matK sequence samples from laboratory samples using nBlast and Megablast for highly similar sequences.

\begin{tabular}{|c|c|c|c|c|c|}
\hline No & Investigated species & Best hit at NCBI database & $\begin{array}{c}\text { Coverage } \\
(\%)\end{array}$ & $\begin{array}{c}\text { Similarity } \\
(\%)\end{array}$ & E-value \\
\hline 1 & H. bancana & H. discolor & 100 & 99 & 0.0 \\
\hline 2 & H. celebica & S. smithiana & 100 & 100 & 0.0 \\
\hline 3 & H. dryobalanoides & H. discolor & 99 & 99 & 0.0 \\
\hline 4 & H. grifithii & S. smithiana & 100 & 100 & 0.0 \\
\hline 5 & H. malibato & H. latifolia & 100 & 99 & 0.0 \\
\hline 6 & H. nigra & H. smithiana & 100 & 100 & 0.0 \\
\hline 7 & H. odorata & H. wightiana & 100 & 99 & 0.0 \\
\hline 8 & H. philippinensis & H. discolor & 100 & 99 & 0.0 \\
\hline 9 & H. plagata & H. wightiana & 100 & 99 & 0.0 \\
\hline 10 & H. sangal & H. jucunda subsp. modesta & 100 & 84 & $3 e-167$ \\
\hline 11 & P. globosa & S. smithiana & 100 & 100 & 0.0 \\
\hline 12 & P. lucida & S. smithiana & 100 & 99 & 0.0 \\
\hline 13 & P. malaanonan & S. smithiana & 100 & 99 & 0.0 \\
\hline 14 & S. acuminata & S. smithiana/S. acuminata & 100 & 100 & 0.0 \\
\hline 15 & S. andulensis & S. smithiana & 100 & 100 & 0.0 \\
\hline 16 & S. balangeran & S. smithiana & 99 & 99 & 0.0 \\
\hline 17 & S. blumuthensis & S. palescens & 100 & 99 & 0.0 \\
\hline 18 & S. chrysophylla & S. smithiana & 100 & 99 & 0.0 \\
\hline 19 & S. faguetiana & S. smithiana & 100 & 100 & 0.0 \\
\hline 20 & S. fallax & S. brachteolata & 99 & 99 & 0.0 \\
\hline 21 & S. guiso & H. wightiana & 100 & 99 & 0.0 \\
\hline 22 & S. hopeifolia & S. brachteolata & 100 & 99 & 0.0 \\
\hline 23 & S. javanica & S. smithiana & 100 & 98 & 0.0 \\
\hline 24 & S. johorensis & S. smithiana & 100 & 99 & 0.0 \\
\hline 25 & S. laevis & S. pallescens & 100 & 99 & 0.0 \\
\hline 26 & S. lepida & S. brachteolata & 100 & 99 & 0.0 \\
\hline 27 & S. leprosula & S. smithiana/S.leprosula & 100 & 99 & 0.0 \\
\hline 28 & S. leptoclados & S. smithiana & 100 & 99 & 0.0 \\
\hline 29 & S. mecystopryx & S. smithiana & 100 & 99 & 0.0 \\
\hline 30 & S. mujongensis & S. kuntslerii & 100 & 99 & 0.0 \\
\hline 31 & S. multiflora & S. xanthophylla & 100 & 99 & 0.0 \\
\hline 32 & S. ochracea & S. seminis & 100 & 99 & 0.0 \\
\hline 33 & S. ovalis & S. smithiana/S.ovalis & 100 & 99 & 0.0 \\
\hline 34 & S. palembanica & S. smithiana & 100 & 99 & 0.0 \\
\hline 35 & S. pauciflora & S. smithiana & 100 & 99 & 0.0 \\
\hline 36 & S. pinanga & S. smithiana & 100 & 100 & 0.0 \\
\hline 37 & S. sandakanensis & S. splendens & 100 & 100 & 0.0 \\
\hline 38 & S. selanica & S. smithiana & 100 & 99 & 0.0 \\
\hline 39 & S. seminis & S. seminis & 100 & 99 & 0.0 \\
\hline 40 & S. smithiana & S. smithiana & 100 & 96 & 0.0 \\
\hline 41 & S. splendida & S. smithiana & 100 & 99 & 0.0 \\
\hline 42 & S. teysmaniana & S. pinanga & 100 & 87 & 0.0 \\
\hline 43 & S. virescens & S. brachteolata & 100 & 100 & 0.0 \\
\hline 44 & S. xanthophylla & S. xanthophylla & 100 & 99 & 0.0 \\
\hline
\end{tabular}




\subsection{Sequence-based identification key using trnL intron as a model}

In the maximum parsimony tree, using $M$. kerstingii as an outgroup and 145 species as an ingroup, 29 subclades were formed. Every subclade had a identical sequence.

Clade 1.

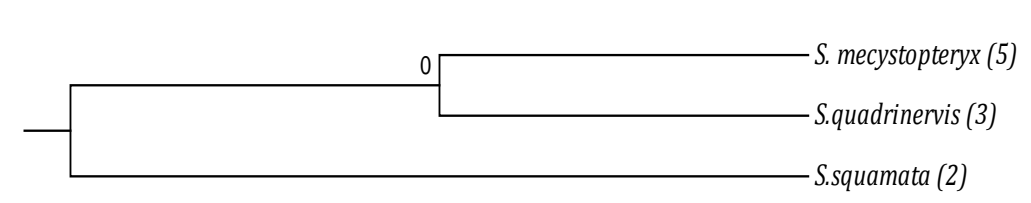

\begin{tabular}{|l|c|c|}
\hline \multirow{2}{*}{\multicolumn{1}{|c|}{ Species }} & \multicolumn{2}{c|}{$\begin{array}{c}\text { Position of polymorphic site } \\
\text { and its characters }\end{array}$} \\
\cline { 2 - 3 } & 52 & 212 \\
\hline S. squamata & - & $\mathrm{G}$ \\
\hline S. mecystopteryx & $\mathrm{A}$ & $\mathrm{G}$ \\
\hline S. quadrinervis & $\mathrm{A}$ & (R) A \\
\hline
\end{tabular}

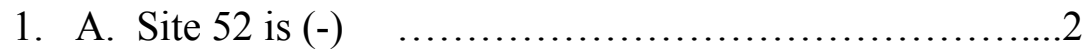

B. If (A) (........................................

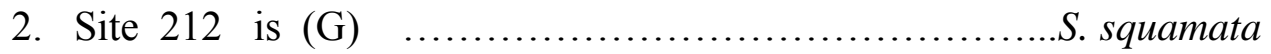

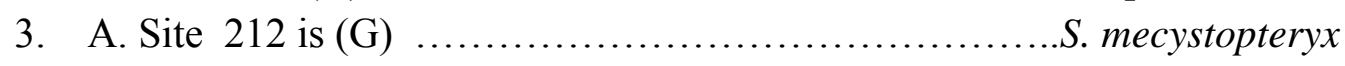

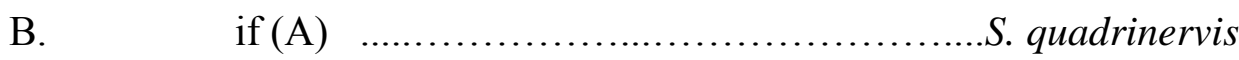

Clade 2

Only comprised one member of Vatica (V. odorata). This species formed a polytomy with the other sequences.

Clade 3.

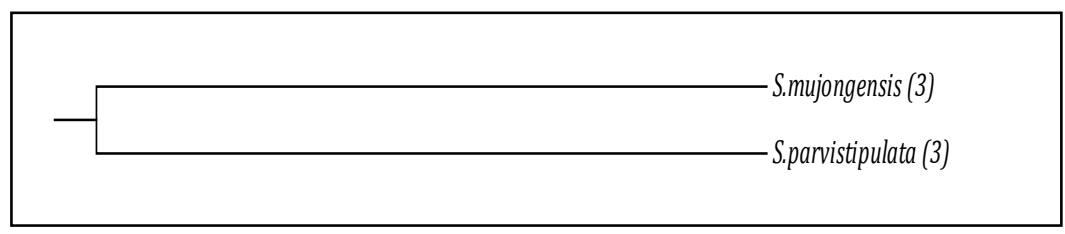

There was no polymorphism between S. mujongensis and S. parvistipulata. These two species showed identical sequences in the trnL intron gene region, therefore these two species cannot be distinguished using the trnL intron. 
Clade 4.

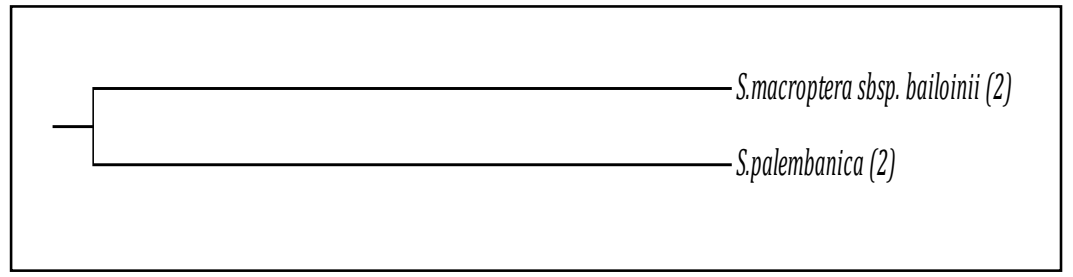

\begin{tabular}{|l|c|c|c|c|}
\hline \multirow{2}{*}{ Species } & \multicolumn{4}{|c|}{ The polymorphic site and its nucleotide } \\
\cline { 2 - 5 } & 244 & 246 & 275 & 276 \\
\hline S. macroptera sbsp. bailonii & - & $\mathrm{G}$ & $\mathrm{A}$ & $\mathrm{C}$ \\
\cline { 2 - 5 } S. palembanica & $\mathrm{A}$ & $\mathrm{R}$ & $\mathrm{M}$ & $\mathrm{Y}$ \\
\hline
\end{tabular}

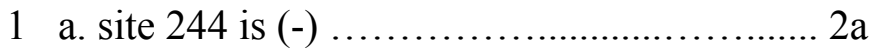

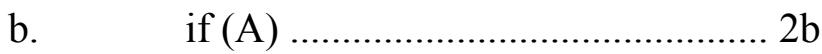

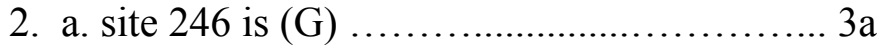

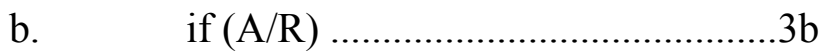

3. a. site 275 is $(\mathrm{A}) \quad \ldots \ldots \ldots \ldots \ldots \ldots \ldots \ldots \ldots$ a

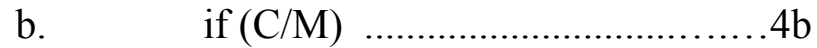

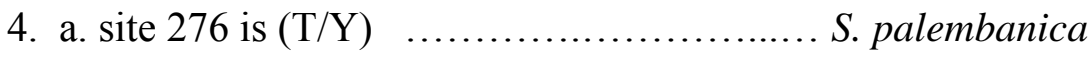

b. If (C) …................................. macroptera subsp. bailonii

Not all the members of the clade could be identified using this key. If the compared species had identical sequences, this gene region was unable to identify them. Our results showed that there were many identical sequences included in one subclade, even though they belonged to different species. This was the case in the $3^{\text {rd }}$ subclade (S. mujongensis and $S$. parvistipulata), $6^{\text {th }}$ subclade (S. javanica and S. pauciflora), $11^{\text {th }}$ subclade (S. andulensis and S. leprosula), $14^{\text {th }}$ subclade (S. paltycarpa and S. stenoptera), $15^{\text {th }}$ subclade (S. palosapis and S. pubystila), $16^{\text {th }}$ subclade (S. blumuthensis and S. havilandii), $17^{\text {th }}$ subclade (S. balangeran, S. lepidota, S. rugosa, S. curtisii), $18^{\text {th }}$ subclade (S. atrinervosa and S. inappendiculata), $19^{\text {th }}$ subclade (S. flaviflora and S. platyclados), $20^{\text {th }}$ subclade (S. falciferoides and S. polysperma), $21^{\text {st }}$ subclade ( . falcifera and S. macroptera), $24^{\text {th }}$ subclade ( . colina and S. domatiosa), $25^{\text {th }}$ subclade ( $P$. lucida, S. amplexicaulis, S. johorensis, S. smithiana), $26^{\text {th }}$ subclade (S. argentifolia and S. rubra), $27^{\text {th }}$ subsubclade (a) (S. patoiensis, S. Richetia and S. gibbosa, S. longiflora, S. maxima, S. faguetioides), $27^{\text {th }}$ subsubclade (b) (S. albida and S. sandakanensis), $27^{\text {th }}$ subsubclade (c) (S. latifolia, H. malibato, H. mengarawan, $H$. philippinensis), $27^{\text {th }}$ 
subsubclade (d) (S. henryana, S. lepida) (S. agami, S. confusa and S. symingtonii). $29^{\text {th }}$ (D. baudii, D. Condorensis; D. grandiflorus, D. kerii, D. tempehes, D. Turbinatus; D. costatus, D. Haseltii). The rest of the identification key is shown Appendix 12. 


\section{Discussion}

\subsection{The phylogeny of Dipterocarpoideae}

Dipterocarpaceae species are known to be difficult to identify, especially when there is no flower available because of their infrequent flowering periods. Additionally, the species are also difficult to differentiate based on morphological characters because many species resemble each other (Symington, 1974).

The data presented here comprise a different number of sequences from a varying number of species from four DNA regions, depending on the sequences' availability in the NCBI and tissue samples in the laboratory. This means that the four regions are not directly comparable, but they do allow examination of the relationship between the groups of taxa in each DNA region.

Since the topology of the three statistical analyses (maximum parsimony, maximum likelihood and neighbor joining) for each region was generally congruent, with only small differences in bootstrap support, the discussion mostly refers to the maximum parsimony method.

\subsubsection{Combination of four chloroplast DNA regions and overview of single regions}

The combination dataset of four chloroplast regions was unable to clearly separate the members of Shorea, Hopea and Parashorea, reflecting the difficulties of using chloroplast DNA to classify the genera into one monophyletic group for each genus. The three statistical methods also formed a stable group within the tree but most of the grouping was paraphyletic. The combined trees produced in this study were representative of the ability of some of the chloroplast genes to resolve the phylogenetic relationship among Shorea, Parashorea and Hopea genera. This result is in accordance with previous results (Dayanandan et al., 1999; Kajita et al., 1998; Rath et al., 1998; Yulita et al., 2005). Thus, neither morphological nor molecular studies have been able to separate Shorea, Hopea and the putative genus Parashorea into three monophyletic groups.

Using M. kerstingii as an outgroup, our results showed that the $\operatorname{trn} \mathrm{L}$ intron gene region is unlikely to reflect the evolutionary relationships of subfamily Dipterocarpoideae's members. 
There are three assumptions for why a polytomy was formed in this tree: (1) recent speciation has occurred, as revealed by this gene region, (2) we don't have enough data to fully resolve the species and (3) there has been hybridization between closely related species. Since the reported data comprised GeneBank data and samples deposited in our laboratory, the sources of sampled species were heterogeneous. The species possibly showed polytomies as a result of internodes occurring in a short period of evolutionary time. The phylogenetic "bushes" in this tree might be because the trnL intron does not contain phylogenetically relevant information to resolve the tree, forming a bifurcating pattern (Humphries and Winker, 2010). The results of a previous study by Taberlet et al.(2007) agrees with this result.

The psbC-trnS IGS has shown the best delineation of the genus Shorea based on a classification by Symington (1943) and Ashton (1982). Since this region was mostly based on data for Shorea, Hopea and Parashorea, we could not assess the ability of this region to infer the complete phylogeny within tribe Dipterocarpeae. However, the parsimony tree of this region showed that Anisoptera and Cotylelobium genera formed an outgroup with $U$. borneensis, while the members of genus Vatica formed a sister branch with other subclades of tribe Shoreae.

The matK gene region in this study was able to resolve tribe Dipterocarpeae and tribe Shoreae. Using M. madagascariensis as an outgroup, this gene was able to resolve two subclades of tribe Dipterocarpeae; one subclade was a monophyletic group of genus Dipterocarpus, and the other a paraphyletic group of other members of tribe Dipterocarpeae. This gene region also succeeded in placing section Doona of genus Shorea into a monophyletic group. Even though this gene region was reported by previous research to have more power to resolve phylogenetic relationships on the intra and inter species levels, the matK gene did not show an ability to resolve the placement of Shorea, Hopea and Parashorea, with the exception of section Doona of the Shorea group.

Analysis of the $r b c \mathrm{~L}$ data revealed that this gene region could not resolve the Dipterocarpaceae group above the generic level. This gene could separate tribes Dipterocarpeae and Shoreae effectively, but the separation within tribe Shoreae is still unclear using this gene. This result agreed with a previous result by Dayanandan et al. (1999), who succeeded in studying the affinity of the Dipterocarpaceae family to the Sarcolaenaceae family and allied with Malvales, but their study could not separate the tribes of Dipterocarpaceae. 
The most important photosynthetic enzyme is encoded by the $r b c \mathrm{~L}$ gene (Zurawski et al., 1981); this gene is extensively used as the first DNA sequenced from plants in plant phylogenetics studies. According to Vijayan and Shou (2010), the $r b c \mathrm{~L}$ gene is the best characterized gene sequence among the plastid genes. However, most phylogenetic studies suggest that this gene is best suited to reconstruct the relationship down to the generic level but not the species level.

\subsubsection{Phylogeny within tribe Dipterocarpeae}

We could retrieve sequence data of tribe Dipterocarpeae for all of the studied DNA regions, but only the trnL intron and matK gene regions provided extensive data compared with the $p s b C$-trnS IGS and $r b c \mathrm{~L}$ gene regions. The $t r n \mathrm{~L}$ intron sequence data of tribe Dipterocarpeae (Anisoptera, Cotylelobium, Dipterocarpus and Vatica) genera in our study were the same as the data used by Nguyen (2009).

Based on our result, the trnL intron region for the three methods showed the same pattern; all trees showed a low resolution and formed a polytomic clade. However, some subclades formed monophyletic groups. The Dipterocarpus group for all three methods showed a stable pattern that was distinct within the subclade. All Dipterocarpus species were grouped together; their affinity was supported by a high bootstrap value (99\%). Nguyen's (2009) results also showed that this genus' members also formed a monophyletic group using nuclear genes (ITS1 and ITS2).

Because Dipterocarpus was only available for the trnL intron and matK gene regions in our dataset, we were only able to observe this genus for those two DNA regions. This genus always formed a unified and distinct group that was separated from the other genera.

The generic relationships of Dipterocarpeae members using the trnL intron and matK gene regions and revealed by the three statistical methods was mostly in accordance with previous results (Dayanandan et al., 1999; Gamage et al., 2006; Nguyen, 2009), which also found that Dipterocarpus always formed a monophyletic group, separated from the other members of tribe Dipterocarpeae and with high bootstrap support, indicating that this genus diverged earlier than other members of Dipterocarpeae. There were several indels found in all members of Dipterocarpus when aligned with another Dipterocarpeae member. These indels 
might be important characters that resolved this group into one monophyletic group (data not shown).

Dipterocarpus may represent the basal lineage of Dipterocarpoideae (Meijer, 1979), and the family's name was taken based on this genus, probably because this genus was a primitive group among Dipterocarpaceae members (Maury - Lechon, 1979). This genus is well defined in the Dipterocarpaceae family, both in terms of morphological characters and molecular analyses. Through its morphological characters, Dipterocarpus can be identified by the large yellow anthers of its flower (2.5-8 cm across), with long appendages and columnar styles that are enclosed in large pink and white petals. There are generally two wing-like fruits. All Dipterocarpus species produce an oleo-resin called minyak keruing (Ashton, 1988; Symington, 1943).

The three statistical methods using the trnL intron showed that the members of Dipterocarpeae, excluding Dipterocarpus, showed an affiliation with members of tribe Shoreae. This gene region was unable to trace the evolutionary relationship among the studied taxa. The three statistical methods did not indicate that the trnL intron gene is a suitable region for studying the evolutionary relationship of dipterocarps. The low ability of the trnL intron region to resolve Dipterocarpaceae members was because of the lower intraspecific variation compared with the other noncoding regions of the chloroplast DNA (Shaw et al., 2005). Despite the fact that this region was easy to amplify, it doesn't represent the best choice either to delimit species or study the phylogenetic relationship among closelyrelated species (Taberlet et al., 2007a)

On the other hand, when using the matK gene region, all the other members of tribe Dipterocarpeae, namely Cotylelobium, Upuna, Anisoptera, Vatica, Vateriopsis and Stemonoporus formed a paraphylethic group and sister clade with Dipterocarpus. This result revealed that the matK gene region was better than the trnL intron in distinguishing the members of tribe Dipterocarpeae. The matK gene region could provide a better depiction of the evolutionary relationships within Dipterocarpeae.

The results of our analyses agreed with those of Gamage et al. (2006), as well as the results of Nguyen (2009), who found that Vateriopsis seychellarum diverged earlier and formed a sister group with the other members of tribe Dipterocarpeae, excluding the Dipterocarpus branch. This species is more morphologically resemblant to Dipterocarpus than the other members of the Dipterocarpaceae family, however, in that it has a micropyle formed by both the inner and outer integument (Oginuma et al., 1999) 
Our results also agreed with the results of Gamage et al. (2006) and Nguyen (2009), who placed the members of genus Stemonoporus in one monophyletic subclade. Stemonoporus is a well-known endemic genus in Sri Lanka. In addition, this genus diverged from the other members of the Dipterocarpeae tribe based on its morphological characters, specifically its peculiar anther with apical dehiscence and apical leaf traces, which separates from the central vascular cylinder well before the node (Ashton, 1982; Gamage et al., 2006; Kostermans, 1981).

On our matK tree, genus Cotylelobium grouped together and formed a sister branch with a monophyletic group of genus Vatica. This was similar to the neighbor joining tree using the psbC-trnS IGS, which showed that C. lanceolatum was a root of the Vatica group. This result agreed with previous studies in placing Cotylelobium in a separate branch from Vatica (Cao et al., 2006; Dayanandan et al., 1999; Gamage et al., 2006; Nguyen, 2009). However, this result was contrary to Kosterman (1981), who placed Cotylelobium in a group with genus Vatica section Sunaptea. Our results supported the results of Indrioko et al. (2006), where genus Cotylelobium diverged earlier than all the members of tribe Dipterocarpeae but Dipterocarpus.

Our matK tree results were similar to previous results by Parameswaran and Gottwald (1979), in placing $U$. borneensis in a sister branch with genus Anisoptera (A. laevis and $A$. marginata). Based on the morphological characters, genus Upuna was similar to Anisoptera and Vatica in medium-large solitary and partial multiple pores $(120-150 \mu \mathrm{m})$, diffuse resin canals, thick-walled fibre and lack of $\mathrm{SiO}_{2}$ (Parameswaran \& Gottwald, 1979).

\subsubsection{Phylogeny within tribe Shoreae}

Our phylogenetic analyses showed similar topologies for all the trees with regard to the separation of tribe Dipterocarpacae and tribe Shoreae. Tribe Shoreae encompasses Shorea, Hopea, Parashorea and Neobalanocarpus. In this tribe, Shorea comprises 196 tree species found in lowland tropical forests in Southeast Asia. The placement of Shorea in our results is also in agreement with the classification proposed by Symington (1943), as well as the classification by Ashton (1982) (Fig 5.1). Symington classified Shorea based on the wood color (Balau, Yellow Meranti, Red Meranti and White Meranti) and treated Pentacme as a separate genus. Meanwhile, Ashton (1982) classified Shorea based on morphological characters, specifically the fruit calix, androecium and bark, separating the genus into 11 
sections and treating Doona and Pentacme as two sections within the group. The sections of Ashton's classification were similar to those in Symington's classification. Sections Doona, Pentacme and Anthoshorea correspond to White Meranti, sections Shorea, Pentacme and Neohopea correspond to Balau and section Richetioides corresponds to Yellow Meranti, while Red Meranti belongs to sections Ovalis, Rubella, Brachyptera, Pachycarpae, and Mutica.

\subsubsection{Placement of genus Shorea}

The placement of Shorea species in our tree was revealed best using the psbC-trnS IGS gene region. The maximum parsimony tree of the psbC-trnS IGS was in accordance with the classifications of previous taxonomists (Ashton, 1982; Symington, 1974). The first clade was paraphyletic because some sections of the Red Meranti group of Shorea (sections Brachyptera, Mutica, Ovalis, Pachycarpae and Rubella) mixed with some members of section Richetioides (Fig. 4.1.a). Meanwhile, other subclades formed a monophyletic group based on the section, which corresponded to wood color.

None of the four studied DNA region trees succeeded in placing the Red Meranti group of Shorea into a monophyletic group, likely because the group is well known to have numerous species among other groups. Red Meranti species are mainly distributed in Sumatra, west Borneo and throughout the Malay Peninsula. The specific characteristics of this group are large, stoutly-buttressed trees, and red, pink, reddish-brown or orange-brown inner bark (Symington,1943). Yulita et. al., (2005), using trnL-trnF and ITS regions, could not resolve Shorea into a monophyletic group separated from genus Hopea, and suggested that the Hopea group may have originated from Shorea. 


\begin{tabular}{|c|c|c|c|}
\hline $\begin{array}{l}\text { Symington } \\
\text { (1943) }\end{array}$ & $\begin{array}{l}\text { Meijer and Wood } \\
\text { (1964) }\end{array}$ & $\begin{array}{l}\text { Maury } \\
\text { (1978) }\end{array}$ & $\begin{array}{l}\text { Ashton } \\
\text { (1982) }\end{array}$ \\
\hline $\begin{array}{l}\text { genus Shorea } \\
\text { Balau group } \\
\text { Isoptera } \\
\text { subgr. } \\
\text { Subgr. } \\
\text { Barbata } \\
\text { subgr. } \\
\text { Yellow } \\
\text { Meranti group } \\
\text { (Damar hitam) } \\
\text { Read Meranti } \\
\text { group } \\
\text { Pauciflora } \\
\text { subgr. }\end{array}$ & $\begin{array}{l}\text { genus Shorea } \\
\text { subg. } \\
\text { Eushorea } \\
\text { Isoptera } \\
\text { subgr. } \\
\text { Ciliata } \\
\text { subgr. } \\
\text { Barbata } \\
\text { subgr. } \\
\text { subg. Richetia } \\
\text { (Damar hitam) } \\
\\
\text { subg. } \\
\text { Rubroshorea } \\
\text { Smithiana } \\
\text { subgr. } \\
\text { Pauciflora } \\
\text { subgr. } \\
\text { Pinanga } \\
\text { subgr. }\end{array}$ & $\begin{array}{l}\text { tribe Shorea } \\
\text { genus Shorea } \\
\text { sect. Shoreae } \\
\text { sect. Barbatae } \\
\text { genus Richetia } \\
\text { sect. Maximae } \\
\text { sect. Richetioides } \\
\text { genus Rubroshorea } \\
\text { sect. Rubellae } \\
\text { sect. } \\
\text { Brachypterae } \\
\text { subsect. } \\
\text { Smithiana } \\
\text { subsect. } \\
\text { tribe Anthoshorinae } \\
\text { genus Anthoshorea } \\
\text { sect. } \\
\text { Anthoshoreae } \\
\text { sect. } \\
\text { Bracteolatae }\end{array}$ & 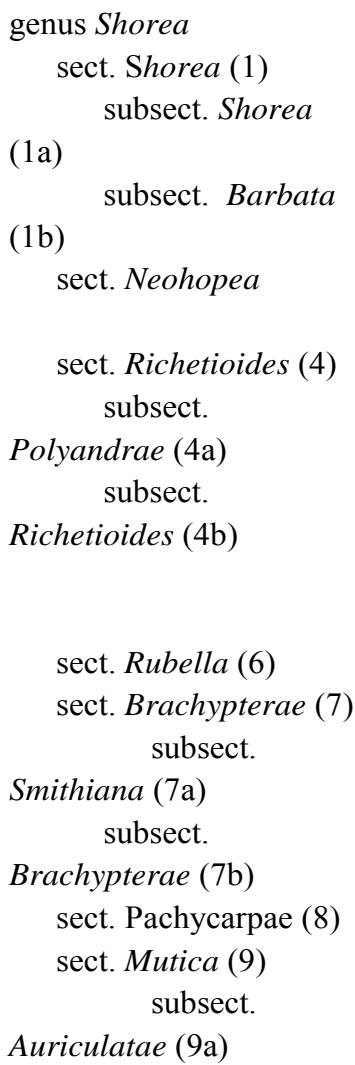 \\
\hline genus Parashorea & genus Parashorea & $\begin{array}{l}\text { tribe Parashorinae } \\
\text { genus Parashorea }\end{array}$ & genus Parashorea \\
\hline
\end{tabular}

Fig 5.1 Comparison of classification of Shorea and its closely-related genera adopted from Kamiya et al. (2005)

Our results are similar to the results of Tsumura et al. (2011), who used the combination of four chloroplast DNA regions (trnL gene, trnL-trnF IGS, trnH-psbA-trnK and psbC-trnS IGS) and succeeded in separating Shorea in a similar manner as phylogenies based on the wood color, with the exception of the White Meranti group, which formed an affiliation with the members of genus Hopea. In the psbC-trnS IGS tree, using maximum parsimony analysis, the subclade of Anthoshorea was resolved as a monophyletic group, supported by a moderate bootstrap value (50\%). According to Symington (1943), based on the production of yellow pale dammar resin, the White Meranti is similar to damar mata kucing, which is produced by some Hopea species.

The psbC-trnS IGS succeeded in resolving section Richetioides, which belongs to the Yellow Meranti group of Shorea as a monophyletic subclade (C in Fig. 4.1), with strong bootstrap support $(100 \%)$. The monophyly of this section agreed with the results of Kamiya et al. 
(2005), who also found that section Richetioides formed a monophyletic group when using the PgiC gene region (Kamiya et al., 2005). Yulita et al., (2005) also reported similar results when using the trnL-trnF IGS region. In addition, besides the psbC-trnS IGS, the $\operatorname{trnL}$ intron tree using maximum parsimony analysis also showed a monophyletic group of section Richetioides, corresponding to the Yellow Meranti group of Shorea (S. faguetioides, S. multiflora, S.peltata, S. longisperma, S. gibbosa, S. acuminatissima, S. richetia, S. maxima, S. longiflora, S. patoiensis). The members of section Richetioides are known in the market as Meranti Damar Hitam. This section is known to have characters that are dissimilar to those of other sections, including subequal calyx lobes, anthers, wood and bark anatomy and dark brown or black dammar exudation (Ashton, 1982; Symington, 1943).

The subclade of section Shorea using the psbC-trnS IGS and the maximum parsimony method (D in Fig. 4.1) agreed with the results of Yulita et al. (2005), who used the trnL-trnF gene regions, as well as the ITS gene regions, and found that section Shorea (Balau group) did not form a monophyletic group, but a paraphyletic one, because of the inclusion of $S$. isoptera from section Neohopea and some sections of the Shorea genus (Brachypterae, Mutica and Anthoshorea). However, in our result, the subclade of section Shorea was not allied with the members of section Brachypterae or other sections from the Red Meranti group of Shorea, instead allying with the members of section Richetioides (S. blumuthensis and S. polysperma).

Using the three statistical methods with the matK gene region resulted in the successful formation of section Doona (S. affinis, S. zeylanica, S. cordifolia, S. gardneri, S. worthingtonii, S. trapezifolia, S. congestiflora, S. disticha, S. megistophylla) into a single monophyletic group, with a high bootstrap value (91\%). Among all the sections of the Shorea genus, section Doona is one of the easiest to characterize. This section consists of ten species, most of them endemic to Sri Lanka. Morphological studies, using Doona's distinct characters, recommend that the section might be grouped in an own, separate genus (Maury Lechon, 1979). However, Ashton (1982) suggested that it should be classified as a section of the Shorea genus. 


\subsubsection{Placement of genus Parashorea}

The phylogenetic tree of the psbC-trnS IGS using maximum parsimoy showed that Parashorea malaanonan formed a sister subclade with all the other subclades of Shorea and Hopea, and was grouped with S. contorta, with a strong bootstrap value (100\%). One member of Parashorea (P. lucida) in this tree allied with the Red Meranti group in the first clade (Fig. 4.1.a). The close relationship between P. malaanonan and S. contorta was also evident in the $r b c \mathrm{~L}$ gene analysis. Based on our phylogenetic analyses of the $r b c \mathrm{~L}$ gene region, the three statistical methods showed that $P$. malaanonan and $S$. contorta always grouped together with high bootstrap support (>97\%). Meanwhile, other members of Parashorea (P. lucida and P. globosa) formed a sister branch with other Shorea members.

According to Parameswaran and Gottwald (1979), genus Parashorea is closely-related to section Pentacme because of their similarities in wood anatomy, solitary and multiple vessels, apotracheal and paratracheal parenchymes, calcium oxalate crystals in rays and resin canals in tangential rows. Some Parashorea members are also morphologically similar to the members of Red Meranti of Shorea (Symington, 1943), while Dayanandan et.al (1999) suggested that this genus is close to the section Anthoshorea and Richetioides are therefore also believed to be closely-related to genus Shorea. According to Ashton (1982), S. contorta is member of section Pentacme. Parashorea malaanonan and Shorea contorta are grouped together; both species have a wide distribution throughout the Philippines (Ashton, 2004), while P. lucida and P. globosa, which are nested with the Red Meranti group, are found only on the islands of Sumatra and Borneo.

The matK gene using maximum parsimony analysis revealed that the placement of Parashorea chinensis was unlike that in the results of Li et al. (2004). Parashorea chinensis and Parashorea chinensis var. kwangsiensis, using the matK gene, trnL-trnF IGS and trnL intron, were affiliated with Parashorea lucida and sistered with S. macroptera and S. ovalis (Li et al., 2004). According to Symington (1943), Parashorea resembles the members of the Red Meranti group of Shorea in leaf characteristics, such as glausescence, particularly in young leaves, needle-like leaves and older seedlings with white subpeltate leaves on the undersurface.

There are several of Parashorea generic characters that don't belong to $P$. chinensis. The nut is ovoid (not cylindrical), and the usually prominent pale lenticels are obscured by the tomentum. Additionally, the leaves are not folded, nor are seedling leaves peltate or silvery 
on the underside, even though the flower is similar of those of the other species of Parashorea (Li et al., 2004).

\subsubsection{Placement of genera Hopea and Neobalanocarpus}

Our parsimony tree of the psbC-trnS IGS region showed that the genus Hopea in the second clade formed a paraphyletic subclade, because of the inclusion of S. astylosa and N. hemii. None of the chloroplast regions in this study could separate Hopea and Shorea into monophyletic groups. The affiliations of Shorea and Hopea genera in all of the phylogenetic trees were similar to those produced by Yulita (2005), who utilized a different chloroplast region (trnL-trnF IGS). Both Kamiya (2005), who used the PgiC gene, and Yulita (2005), who used the ITS gene, found a monophyletic group of Hopea, with the exception of $H$. celebica in Yulita's analysis, which was nested with Shorea group. These results suggest that nuclear genes are more effective than chloroplast genes when classifying the Hopea group. According to Ashton (1988) morphological characteristics of Hopea can distinguish it from Shorea, such as the number of long fruit calyxes and height of their members.

Our psbC-trnS IGS tree showed that Neobalanocarpus hemii formed a sister branch with the Hopea group, agreeing with the classical taxonomic work of Ashton (Ashton, 1982) and previous results from Gamage et al. (2006), Tsumura et al. (1996) and Yulita et al. (2005), but contrary to a previous result from Kamiya (Kamiya et al., 2005), who had used part of the PgiC gene and found that Neobalanocarpus was nested in section Anthoshorea of the Shorea group. Kamiya et al. (2005) assumed that the origin of Neobalanocarpus is the result of hybridization between Hopea and White Meranti of Shorea, with the former as the maternal progenitor and the latter as paternal. However, our maximum parsimony tree of the matK gene showed a paraphyletic subclade in which $N$. hemii was nested together with Hopea, and Shorea section Anthoshorea (S. brachteolata and S. virescens), Richetioides (S. hopeifolia), and section Balau (S. guiso). These results cannot fully support the assumtion of Kamiya et al. (2005), whose hypothesis could be acceptable if the paternal progenitor was not restricted to the White Meranti group of Shorea, but the whole genus in general.

According to the argumentation of Parameswaran and Gottwald (Parameswaran \& Gottwald, 1979 ) and Ashton (1982) which is based on its morphological characters, Neobalanocarpus is more closely-related to the Hopea group than the Shorea group, owing to the similarities in inflourescence features, embryo structure and germination modes, as well as leaves and wood 
anatomy. Asthon (Ashton, 1982) has strongly suggested that N. heimii is closely-related to the genus Hopea, and his suggestion has been supported by subsequent research by Kajita et al., (1998).

\subsubsection{Placement of genus Dryobalanops}

Our parsimony tree of the matK and trnL intron gene regions showed different result in the placement of the position of genus Dryobalanops. The matK gene showed an affinity of this genus to genus Dipterocarpus and formed sister subclade with the outgroup (Monotes madagascariensis). This result is in agreement with the previous result of Indrioko (2005) using chloroplast microsatelite analyses and Yulita et al. (2005) using the trnL-trnF region that genus Dryobalanops forms a sister taxon with the Shorea, Hopea and Parashorea genera. Meanwhile, the three methods of the trnL intron statistical analysis showed that this genus nested with the Shorea group. The maximum likelihood tree of the trnL intron showed that Dryobalanops oblongifolia formed a sister branch with S. seminis. This result was similar with the result of ITS analysis of Yulita et.al (2005). In her result using that nuclear gene region, the genus Dryobalanops was placed within the genus Shorea clade.

According to Indrioko (2005) the genus Dryobalanops is morphologically similar to tribe Dipterocarpeae; he suggested that this genus is a basal of the Shoreae tribe. However, according to Symington (1943), the genus Dryobalanops is similar with genus Dipterocarpus, section Balau of the Shorea group and some species of the Hopea genus in having a scaly bark. Our result using the matK gene agree to place genus Dryobalanops close to genus Dipterocarpus, while our trnL intron tree showed a relationship of this genus to the member of section Balau (S. seminis) which can support the assumption of Indrioko (2005) that this genus is the basal lineage of tribe Shoreae. 


\subsection{Utilizing two DNA barcode regions (matK and $r b c L$ ) for dipterocarps}

Using the $r b c \mathrm{~L}$ gene and the maximum parsimony method, the tribes Shoreae and Dipterocarpeae were successfully separated. However, the ability of this gene to distinguish the members of Shoreae was low (Appendix 11) because the $r b c \mathrm{~L}$ gene does not have sufficient variation at the species level. Although the $r b c \mathrm{~L}$ gene has been used extensively in familial level phylogenetic studies (Gielly and Taberlet, 1994), it is reported to evolve slowly (Soltis et al., 1998). Our result agreed with previous research of the Dioscorea genus by Sun et al. (2012), in finding that the $r b c \mathrm{~L}$ gene was not capable of discriminating species but genera and above.

Thus, to be used as a DNA barcode, it appears that the $r b c \mathrm{~L}$ gene region cannot work alone. This gene region should be combined with gene regions to improve its discriminatory power.

Amplification of the matK gene using the universal matK primer proposed by Kim (Hollingsworth, 2011) was difficult. Additionally, compared with the $r b c \mathrm{~L}$ gene, the sequencing results were of low quality. These results were similar to previous results regarding different taxa (de Vere et al., 2012; Hollingsworth et al., 2011; Yu et al., 2011).

Our results showed that using nBLAST in concert with the matK gene can lead to an identification of the correct genus (84\%). However, nBLAST's results can be misleading on the species level, possibly because the sequences deposited in NCBI that corresponded to our samples were limited. Additionally, the matK region was conserved which was showen by the of E-values for almost all the species. The lower the E-value, the more similar the query sequence to the hit sequences in the database (Madden, 2002). Even though according to Olmstead and Palmer (1994) matK is the most variable coding region among cpDNA, our results showed that this region is very conserved for Dipterocarp species. BOLD is thus required because it will provide a more reliable database than the NCBI for DNA barcoding. Little and Stevenson (2007) have suggested that using a reference database in which virtually all haplotypes in all species are represented will provide the most reliable identification.

The neighbor joining trees revealed that some of the matK sequences analyzed in our laboratory allied with the corresponding sequences from the same species available in the NCBI database. The ability of most of the sequences from the laboratory analyses to group together based on the same genus revealed that this gene region is able to discriminate sequences above specific level. However, the neighbor joining tree of this region showed 
many polytomies, indicating that this gene region is not able to effectively trace the evolutionary relationships of species.

The combination of the two DNA regions (matK and $r b c \mathrm{~L}$ ) was not able to distinguish the Shorea, Hopea and Parashorea genera as one monophyletic group (Fig. 4.6). This combination of regions was able to separate the 40 species into two paraphyletic clades with strong bootstrap support (98\%). The first clade was dominated by Shorea members, whereas the second clade was dominated by Hopea members. The difficulties of resolving Shorea, Hopea and Parashorea are because all three generas' members are closely-related species (Kress et al., 2009; Yulita et al., 2005). The difficulties in using these two regions as barcode regions for closely-related species were also revealed in a previous research (Zhang et al., 2012), who analyzed Lysimachia L. (Myrcinaceae family), and found the impossibility of using the $r b c \mathrm{~L}$ and matK gene regions together as barcode regions to distinguish closelyrelated species in Myrcinaceae. For dipterocarps, even though the matK gene showed a moderate discriminatory power, many polytomies were formed in the resulting tree, suggesting its low ability to reveal the phylogeny of dipterocarps.

\subsection{Sequence-based identification key}

The presented results show that we were unable to produce a reliable identification key for identifying members of the Dipterocarpaceae family. The weakness of this key is that many identical sequences belong to different species; that is, multiple occasions were encountered in which one haplotype would belong to different species. The investigated gene regions were not suitable for distinguishing species, particularly closely-related ones. Other gene regions may be more suitable for dipterocarp species identification. Further research on the possibility of developing a molecular taxonomic identification key based on phylogenetic analyses is needed. 


\section{Conclusion and Outlook}

The Dipterocarpaceae family dominates the lowland forests of Southeast Asia. It is divided into three subfamilies: Dipterocarpoideae, Pakaraimoideae and Monotoideae. Most of the genera in this family belong to species that produce valuable timber. Subfamily Dipterocarpoideae is the largest group and, based on the basic chromosome number, divided into two tribes, Shoreae $(\mathrm{X}=7)$ and Dipterocarpeae $(\mathrm{x}=11)$, with genus Shorea containing the highest number of species.

The evolutionary relationship between the members of subfamily Dipterocarpoideae was inferred using four chloroplast regions: trnL intron, psbC-trnS IGS, matK and rbcL. This study also aims to evaluate DNA-based identification using DNA barcoding and a molecular taxonomic identification key.

The phylogenetic analysis using the four chloroplast regions and three statistical methods (maximum parsimony, maximum likelihood and neighbor joining) resulted in successful placement and revealing of the relationship between Dipterocarpoideae's members. None of the four chloroplast regions showed a single DNA region as suitable to delineate the evolutionary relationships of dipterocarps, with every chloroplast region having its own specifities.

The trnL intron region was easy to amplify; it is the most-used region to infer the evolutionary relationship among plant species (Taberlet et al., 2007b; Zhou et al., 2008). However, this region was only able to resolve the taxa up to the generic level, separating tribes Dipterocarpeae and Shoreae most effectively using the maximum likelihood and maximum parsimony methods, although maximum parsimony could only clearly distinguish the Dipterocarpus genus into one monophyletic group.

The suitability of the $p s b$-trnS IGS region for tracing the evolutionary relationships between plants is controversial because of the limited research on this region. When combined with other chloroplast regions, however, this region succeeded in resolving the Shorea genus in agreement with phylogenies based on the wood color (Tsumura et al., 2011). Our results showed that this region works well in distinguishing species based on wood color and separated them into several monophyletic groups.

The matK gene region is recommended in many phylogenetic studies because of its ability to resolve phylogenetic relationships at the intra and interspecific level. In our study, the matK 
gene was the best at revealing the evolutionary relationship of the members of Dipterocarpeae and could distinguish section Doona in tribe Shoreae, placing the members in a monophyletic group. However, this region could not reveal a clear distinction of Shoreae, because this tribe formed a paraphyletic group in which the members of Shorea, Hopea, Parashorea and Neobalanocarpus allied together in the clades.

The $r b c \mathrm{~L}$ gene region was similar to the $\operatorname{trn} \mathrm{L}$ intron in its ability to amplify easily and provide a satisfactory sequencing product. However, this gene region did not show an ability to infer the evolutionary relationships within tribe Shoreae.

The placement of the members of Shoreae was generally unclear in this study. Genus Shorea was paraphyletic because three other genera, Hopea, Neobalanocarpus and Parashorea were nested with it. However, the classification within Shorea could be revealed using the psbCtrnS IGS region and matK gene region, since some of the subclades formed a monophyletic group based on the section, which corresponded to wood color. In this study, the psbC-trnS IGS placed Neobalanocarpus as a sister branch with Hopea, while the matK gene tree showed this genus' affinity with Shorea (sections Anthoshorea, Richetioides and Balau) and Hopea. Our study showed that using the matK gene resulted in genus Dryobalanops showing an affinity with genus Dipterocarpus, while the trnL intron tree showed that this genus is close to section Balau of the Shorea group

As the four chloroplast regions used in this study could not reveal unambiguous evolutionary relationships, particularly in tribe Shoreae, it is recommended that nuclear genes should be analyzed in a future study. In addition, it is also recommended that the status of the genera Shorea, Hopea and Parashorea should be revised because of their strong affinity in each investigated chloroplast region.

The matK and $r b c \mathrm{~L}$ regions were tested for their suitability as barcode DNA. Our study showed that the matK gene region was difficult to amplify and showed a lesser discriminatory power at the species level particularly for tribe Shoreae. The $r b c \mathrm{~L}$ gene was easy to amplify, while failing to provide enough information to discriminate until the species level. Both of these regions were only partially suitable to clarify the phylogeny of dipterocarps and to reliably identify species, possibly because closely-related species have many constraints that prevent them from being easily distinguished. These gene regions might be of use as barcode DNA for distant relatives if the matK gene can be amplified. 
It is suggested that another chloroplast region, trnH-psbA, should also be analyzed, as recommended by CBOL. Moreover, the nuclear gene ITS2 should also be tested as a barcode region, even though until now this region is recommended only for the fungi group. Since it is difficult to find a single universal barcode region for all land plants, I suggest that taxonspecific barcode regions are used instead.

This study could not provide a universal molecular taxonomic identification key for dipterocarps. Several haplotype sequences could not be unambiguously assigned to a single species.

Because this key aims to complement DNA barcoding analyses, besides applying nBLAST and using the results of phylogenetic tree analyses, I suggest that future studies develop a key from the phylogenetic tree of a barcode gene region. This phylogenetic tree will be a standard tree for each family, comprising as many members of the family as possible. I also recommend that a digital key is developed instead of a paper-based one to facilitate an easy way of species discrimination and identification. 


\section{Summary}

Dipterocarpaceae is the main timber family of tropical forest trees in the Malesian region with a geographical distribution that extends to South America and Africa. The family comprises approximately 500 species in 17 genera and is subdivided into three subfamilies: Dipterocarpoideae, Monotoideae and Pakaraimoideae (Ashton, 1982). Dipterocarpoideae is the richest in species with a total of 470 species in 13 genera (Ashton, 1982). Dipterocarpoideae is divided into two tribes: Dipterocarpeae and Shoreae. The genera of Dipterocarpeae are Anisoptera, Cotylelobium, Dipterocarpus, Stemonoporus, Upuna, Vateria and Vateriopsis, while those of Shoreae are Dryobalanops, Hopea, Neobalanocarpus, Parashorea and Shorea. Shorea and Hopea contain most species; 169 in the former and 100 in the latter.

Molecular phylogenies of the subfamily Dipterocarpoideae have been studied since 1998, especially the genus Shorea and its sister genera in tribe Shoreae, because this genus has the highest number of species and the most valuable timber of the Dipterocarpaceae. Many of these species are endangered. The purpose of molecular phylogenies is to complement phylogenies based on morphology as there is still a debate on the placement of some genera in the tribe Dipterocarpoideae. The classification of Shorea in this research refers to Ashton (1982) and Symington (1943). Symington (1943) has divided Shorea based on wood color (White Meranti, Yellow Meranti, Balau and Red Meranti). Asthon (1982) has generally retained the classification by Symington (1943), but some of the groups were reclassified into lower taxonomical ranks.

The need for identification tools for Dipterocarpacae in order to avoid fraud in certifying the family's timber has led to an improvement in modern identification systems that use molecular data. Traditionally, Dipterocarpaceae are recognized based on their morphological characters, but sometimes these characters have constraints, particularly in the absence of a flower, the most useful taxonomic identification character for the dipterocarps.

The abundance of molecular data as well as advanced technologies in DNA sequencing have made DNA barcoding a widely-used practice in many different fields of taxonomic studies, not as a replacement but as a complement to traditional taxonomy and to accelerate the identification process. Another advantage of the large number of sequences available in public data bases as the NCBI database is that it can lead to a new concept of species 
identification through the development of a molecular taxonomic key. However, since DNA barcoding methods are still in their infancy, the database for DNA barcoding is still being established.

This study aims to infer the phylogenetic relationships of the members of the subfamily Dipterocarpoideae and to study the placement of the genera based on four chloroplast regions (trnL intron, psbC-trnS IGS, matK and $r b c \mathrm{~L}$ ). Furthermore, the suitability of the two barcoding regions (matK and $r b c \mathrm{~L}$ ) will be evaluated, which were proposed by the Consortium for the Barcode of Life (CBOL) in 2009. This study also aims to develop a taxonomic identification key based on the phylogenetic analysis for species identification purposes.

Dipterocarpacae sequences that were deposited in the NCBI database were retrieved for four chloroplast regions (trnL intron, psbC-trnS IGS, matK and $r b c \mathrm{~L}$ ). In addition to the analysis of the sequences from the NCBI database, we also sequenced samples of dipterocarps available at the section Forest Genetics and Forest Tree Breeding, Georg-August-University Göttingen, at the four chloroplast regions in order to analyze the highest possible number of species.

The phylogenetic analysis was done using MEGA 5 software and the statistical methods of maximum parsimony (MP), maximum likelihood (ML) and neighbor joining (NJ). For the DNA-based identification analyses, we evaluated the suitability of the two barcode regions using nBLAST, and performed the phylogenetic analysis using the neighbor joining method.

Our results succeeded in obtaining sequences for various numbers of species for each studied chloroplast region, namely 145 species for the trnL intron, 117 species for the psbC-trnS IGS, 116 species for the matK region and 67 species for the $r b c L$ region. The final length of the sequences varied for each region, $537 \mathrm{bp}, 1136 \mathrm{bp}, 653 \mathrm{bp}$ and $647 \mathrm{bp}$ for the trnL intron, psbC-trnS IGS, matK and $r b c \mathrm{~L}$, respectively.

For the phylogenetic analyses, MP, ML and NJ analyses of cpDNA sequences produced similar tree topologies. As a result, our discussion is mostly based on the results of the MP analysis. Generally, the evolutionary relationships within the subfamily Dipterocarpoideae could not be clearly revealed by the four chloroplast regions. The regions were able to resolve the tribes Dipterocarpeae and Shoreae, but were less successful within the tribes, particularly Shoreae. For the genus Dipterocarpus, recent studies only provide sequence data for the regions trnL intron and matK. We observed two distinct groups comprising species of this 
genus for both gene regions. There is an assumption that Dipterocarpus may represent the basal clade of Dipterocarpoideae (Meijer, 1979). The name of this family was taken based on this genus, possibly because it is regarded as a primitive group among Dipterocarpaceae's members (Maury - Lechon, 1979). This genus is well defined in the Dipterocarpaceae family based on morphological characters and molecular analyses.

The psbC-trnS IGS region in this study agreed with previous research by Symington (1943) in its ability to form a monophyletic group based on wood color in the genus Shorea. The matK region showed the best ability to delineate the relationships of the tribe Dipterocarpeae and succeeded in distinguishing section Doona of Shorea as a monophyletic group. However, this region failed to work as well in classifying other members of Shoreae. Despite the $r b c \mathrm{~L}$ region's status as the first DNA region to be sequenced from a chloroplast region, there are few $r b c L$ sequences available for dipterocarps in the NCBI database. The results based on the data from the laboratory showed that this region was unable to trace the evolutionary relationship of Dipterocarpoideae below the generic level. The matK region in this study showed that the genus Dryobalanops has an affinity with genus Dipterocarpus, while the trnL intron tree showed that Dryobalanops is close to section Balau of the Shorea group. These contradictory results support the assumption of Indrioko (2005) that this genus is a basal clade of tribe Shoreae.

The DNA-based identification was studied using two approaches, namely DNA barcoding and a molecular taxonomic identification key. The two DNA barcode regions, matK and $r b c \mathrm{~L}$, adopted from the Consortium for the Barcode of Life for land plants (Hollingsworth et al., 2009), were applied to assess the feasibility of these regions as barcodes to discriminate the Dipterocarpaceae. Most information for the matK region was available in the NCBI database, but additional samples were also included in this study. In total, 119 and 67 samples were studied using the matK and $r b c \mathrm{~L}$ regions, respectively. The effectiveness of the barcode analysis in this study was assessed by the formation of monophyletic groups of the query sequences and the reference sequences which are deposited in NCBI using neighbor joining trees and then searching for the similarity of the query sequences from the laboratory against the available data in the NCBI database using nBLAST. Although the neighbor joining tree placed some of the sequences in the correct genus, this region could not clearly separate the genera Shorea, Hopea and Parashorea into one distinct group for each of them. The nBLAST analysis resulted in most of the query sequences leading to misidentification at the species level. Because of the low ability of the matK region for species discrimination, as 
indicated by nBLAST and phylogenetic analysis, along with the difficulty in amplifying it, makes this region unsuitable as a barcode region for Dipterocarpaceae. Regarding the $r b c \mathrm{~L}$ region, we could not observe any affiliation of the query sequences from the laboratory since only several sequences of this region are available in the databases. However, based on our neighbor joining analysis, we observed that this region is able to discriminate above the generic level but not the specific level.

DNA-based identification using a taxonomic identification key indicated that the approach is not yet a suitable tool to discriminate species. Many species belonging to the same haplotype were detected when constructing the key. A possible reason for this is the use of the trn $\mathrm{L}$ intron region to construct the key. Taberlet et al., (2007) has reported that this region is not effective in distinguishing closely-related species. 


\section{Zusammenfassung}

Die Arten der Familie der Dipterocarpaceaen (Flügelfruchtgewächse) sind in der Region Malesien die Hauptbaumarten in Bezug auf Holzgewinnung. Die geografische Verbreitung der Pflanzenfamilie erstreckt sich bis Südamerika und Afrika. Die Familie umfasst etwa 500 Arten in 17 verschiedenen Gattungen und ist unterteilt in drei Unterfamilien: Dipterocarpoideae, Monotoideae und Pakaraimoideae (Ashton, 1982). Dipterocarpoideae ist mit 470 Arten in 13 Gattungen die artenreichste Unterfamilie (Ashton, 1982). Sie ist noch einmal unterteilt in zwei Triben: Dipterocarpeae und Shoreae. Dipterocarpeae umfasst die Gattungen Anisoptera, Cotylelobium, Dipterocarpus, Stemonoporus, Upuna, Vateria und Vateriopsis, Shoreae die Gattungen Dryobalanops, Hopea, Neobalanocarpus, Parashorea und Shorea. Shorea und Hopea sind mit 169, bzw. 100 Arten die artenreichsten Gattungen.

Studien zur molekularen Phylogenie der Unterfamilie Dipterocarpoideae werden bereits seit 1998 durchgeführt, besonders an der Gattung Shorea und ihren Schwestergattungen im Tribus Shoreae, da diese Gattung die höchste Artenzahl aufweist und von allen Dipterocarpaceaen das wertvollste Holz liefert. Viele dieser Arten sind vom Aussterben bedroht. Ziel von Untersuchungen zur molekularen Phylogenie ist die Vervollständigung von Phylogenien, die auf morphologischen Merkmalen beruhen, da die Einordnung von einigen Gattungen im Tribus Dipterocarpoideae noch immer zur Diskussion steht. Die Klassifizierung von Shorea in dieser Untersuchung bezieht sich auf Ashton (1982) und Symington (1943). Symington (1943) unterteilt Shorea basierend auf der Farbe des Holzes (White Meranti, Yellow Meranti, Balau und Red Meranti). Ashton (1982) hat die Klassifizierung von Symington (1943) grundsätzlich beibehalten, aber einige der Gruppen wurden in niedrigere taxonomische Ränge neu klassifiziert.

Die Nachfrage nach Identifikationsmöglichkeiten für Dipterocapaceaen zur Vermeidung von Betrug bei der Zertifizierung von Holz hat $\mathrm{zu}$ einer Verbesserung moderner Identifikationssysteme geführt, die auch molekulare Daten nutzen. Traditionell werden Dipterocarpaceaen anhand von morphologischen Merkmalen identifiziert. Allerdings ist diese Art der Bestimmung ist oft nur eingeschränkt nutzbar, vor allem wenn keine Blüte vorhanden ist, da dies das eindeutigste taxonomische Bestimmungsmerkmal bei Dipterocarpaceaen ist.

Die große Menge molekularer Daten und die fortschrittlichen Technologien im Bereich der DNA-Sequenzierung ermöglichten es dem DNA-Barcoding zu einer weitverbreiteten 
Technik für verschiedene taxonomische Studien zu werden. Dabei will es die traditionelle Taxonomie nicht ersetzen, sondern ergänzen und den Identifikationsvorgang beschleunigen. Zusätzlich ermöglicht die große Anzahl an verfügbaren Sequenzen in öffentlichen Datenbanken, wie z.B. die NCBI-Datenbank, die Entwicklung eines molekularen taxonomischen Schlüssels, einem neuen Konzept der Artidentifikation. Allerdings sind die Methoden des DNA-Barcoding noch immer in ihren Anfängen, so wird z.B. die Datenbank für das Projekt DNA Barcoding zurzeit noch eingerichtet.

Diese Studie hat zum Ziel, mithilfe von vier Chloroplastenregionen (trnL intron, psbC-trnS IGS, matK und $r b c \mathrm{~L}$ ) die phylogenetischen Beziehungen in der Unterfamilie Dipterocarpoideae zu erschließen, sowie die Einordnung der verschiedenen Gattungen. Zusätzlich prüft diese Untersuchung auch die Eignung der beiden Barcoding-Regionen matK und $r b c \mathrm{~L}$, die vom Konsortium Barcode of Life (CBOL) im Jahr 2009 vorgeschlagen wurden. Ein weiteres Ziel ist die Entwicklung eines taxonomischen Identifizierungsschlüssels für die Identifizierung von Arten basierend auf der phylogenetischen Analyse.

Alle Sequenzen von Dipterocarpaceaen, die in der NCBI-Datenbank hinterlegt sind, wurden für vier Chloroplastenregionen (trnL intron, psbC-trnS IGS, matK und $r b c \mathrm{~L}$ ) abgerufen. Zusätzlich zu den Sequenzen aus der NCBI-Datenbank wurden für die Untersuchung auch Proben sequenziert, die in der Abteilung Forstgenetik und Forstpflanzenzüchtung der Universität Göttingen zur Verfügung standen, um eine höchstmögliche Zahl von unterschiedlichen Arten untersuchen zu können.

Für die phylogenetischen Analysen wurde die Software MEGA 5 verwendet und die statistischen Methoden maximum parsimony (MP), maximum likelihood (ML) und neighbor joining (NJ). Für die DNA-basierte Identifizierung wurde die Eignung von zwei BarcodingRegionen mithilfe von nBLAST getestet. Die phylogenetische Analyse wurde unter Verwendung der neighbor joining-Methode durchgeführt.

Es war für eine große Anzahl von Arten möglich, Sequenzen von den oben genannten Chloroplastenregionen zu erhalten: 145 Arten für trnL intron, 117 Arten für psbC-trnS IGS, 116 Arten für matK und 69 Arten für $r b c L$. Die Länge der Sequenzen für die verschiedenen Regionen variierte, 537 bp, 1136 bp, 653 bp und 647 bp für die Regionen trnL intron, psbCtrnS IGS, matK bzw. rbcL.

Die verschiedenen Methoden MP, ML und NJ für die phylogenetischen Analysen erzeugten sehr ähnliche Baumtopologien. Daher basiert die Diskussion vor allem auf den Ergebnisse 
der MP-Methode. Grundsätzlich war es nicht möglich, die evolutionären Beziehungen der Unterfamilie der Dipterocarpoideae anhand der vier Chloroplastenregionen eindeutig zu entschlüsseln. Die Regionen ermöglichten nur eine Aufklärung der Triben Dipterocarpeae und Shoreae, waren aber innerhalb der Triben deutlich weniger erfolgreich, vor allem in Bezug auf Shoreae. Für die Gattung Dipterocarpus stehen bisher nur Sequenzdaten der Regionen trnL intron und matK zur Verfügung. In dieser Studie wurden für beide Regionen eindeutig abgrenzbare Gruppen von Arten entdeckt. Es wird vermutet, dass Dipterocarpus die basale Gruppe der Dipterocarpoideae repräsentiert (Meijer, 1979). Diese Gattung hat der Familie auch ihren Namen gegeben, möglicherweise weil sie als eine sehr ursprüngliche Gruppe innerhalb der Dipterocarpaceaen gilt (Maury - Lechon, 1979). Auch ist diese Gattung innerhalb der Familie der Dipterocarpaceaen eindeutig definiert, basierend auf morphologischen Merkmalen und molekularen Analysen.

Die Analysen der Region psbC-trnS IGS bestätigten die Ergebnisse von Symington (1943) basierend auf der Farbe des Holzes dahingehend, dass die Gattung Shorea eine monophyletische Gruppe bildet. Durch die Analyse der Region matK war es am ehesten möglich, die Beziehungen innerhalb des Tribus Dipterocarpeae zu beschreiben und die Sektion Doona innerhalb der Gattung Shorea als monophyletische Gruppe abzugrenzen. Allerdings war diese Region nicht geeignet für die weitere Klassifizierung innerhalb des Tribus Shoreae. Obwohl die Region $r b c \mathrm{~L}$ die erste Chloroplastenregion ist, die sequenziert wurde, sind in der NCBI-Datenbank nur wenige Sequenzen verfügbar. Die Ergebnisse basierend auf den eigenen Labordaten führten zu dem Schluss, dass diese Region nicht geeignet ist, um die evolutionären Beziehungen der Dipterocarpoideae unterhalb der Gattungsebene aufzuzeigen. Die Region matK zeigte in dieser Untersuchung eine nahe Verwandtschaft zwischen den Gattungen Dryobalanops und Dipterocarpus, während die Region trnL intron eher darauf hindeutete, dass Dryobalanops eine Verwandtschaft zur Sektion Balau aus der Shorea-Gruppe aufweist. Diese gegensätzlichen Ergebnisse unterstützen die Annahme von Indrioko (2005), dass diese Gattung eine basale Gruppe des Tribus Shoreae ist.

Die Artidentifizierung basierend auf DNA-Daten wurde anhand von zwei Vorgehensweisen untersucht, DNA-Barcoding und ein molekularer taxonomischer Identifizierungsschlüssel. Die zwei Barcode-Regionen matK und $r b c \mathrm{~L}$, übernommen vom Consortium for the Barcode of Life für Landpflanzen (Hollingsworth et al., 2009), wurden auf ihre Eignung als Barcoding-Regionen für die Unterscheidung der Dipterocarpaceae geprüft. Die meisten 
benötigten Informationen für die Region matK waren in der NCBI-Datenbank vorhanden, aber es wurden auch einige zusätzliche Proben in dieser Studie verwendet. Insgesamt wurden 119 bzw. 67 Proben für die Untersuchung der Region matK bzw. rbcL, verwendet. Für die Beurteilung der Effektivität der Barcoding-Analyse in dieser Untersuchung wurden zunächst mithilfe von neighbor joining-Bäumen monophyletische Gruppen einmal für die Eingabesequenzen und einmal für die Referenzsequenzen, die in der NCBI-Datenbank hinterlegt sind, identifiziert. Unter Verwendung von nBLAST wurde dann nach Ähnlichkeiten zwischen den Eingabesequenzen aus dem Labor und den Sequenzen aus der NCBI-Datenbank gesucht. Obwohl der neighbor joining-Baum einige der Sequenzen in die korrekte Gattung eingeordnet hat, konnte diese Region keine drei klar abgetrennten Gruppen für die Gattungen Shorea, Hopea und Parashorea erstellen. Die nBLAST-Analyse ergab für die meisten Eingabesequenzen auf der Artebene eine falsche Identifizierung. Aufgrund der fehlenden Unterscheidung zwischen Arten durch die Region matK, was nicht nur durch die Ergebnisse des nBLAST, sondern auch durch die phylogenetische Analyse deutlich wurde, und der Probleme bei der Amplifizierung ist diese Region ungeeignet als Barcoding-Region für die Familie der Dipterocarpaceaen. Über die Region $r b c \mathrm{~L}$ kann keine weitere Aussage gemacht werden, da nur wenige Sequenzen für diese Region in der Datenbank verfügbar waren. Allerdings konnte die neighbor joining-Analyse zeigen, dass diese Region erfolgreich auf der Gattungsebene unterscheidet, aber nicht auf der Artebene.

Das DNA-basierte Identifizierungsverfahren unter der Verwendung eines taxonomischen Identifizierungsschlüssels kann noch nicht ausreichend zwischen Arten unterscheiden. Viele verschiedene Arten mit dem gleichen Haplotypen wurden bei der Erstellung des Schlüssels gefunden. Ein möglicher Grund ist die Verwendung der Region trnL intron für die Erstellung des Schlüssels. Taberlet (2007) berichtet, dass diese Region nicht effektiv ist bei der Unterscheidung zwischen nah verwandten Arten. 


\section{References}

Apanah S. (1993). Mass flowering of dipterocarp forest in the aseasonal tropics. Journal of Bioscience 18 (4): $457-474$

Ashton P.S. (1979) Phylogenetic speculation on dipterocarpaceae. In: Maury-Lechon G (ed) Dipterocarpacees, Taxonomie-Phylogenie-Ecologie Memoires du Museum National d'Histoire Naturelle. Paris. Series B, Botanique 26: 145-149

Ashton P.S. (1982) Dipterocarpaceae. In: Van Steenis CGGJ (ed) Flora malesiana. Series I. Spermatophyta. 9: 237 - 552

Ashton P.S. (1988) Dipterocarp Biology as a Window to the Understanding of Tropical Forest Structure. Annual Review of Ecology and Systematics 19:347-370

Ashton P.S. (2004) Dipterocarpaceae. In E. Soepadmo, L.G. Saw and R.C.K. Chung (ed) Tree Flora of Sabah and Sarawak, 5: 63-338. Forest Research Institute Malaysia, Kuala Lumpur

Ashton P.S., Gan Y.Y., Robertson F.W. (1984) Electrophoretic and Morphological Comparisons in 10 Rain-Forest Species of Shorea (Dipterocarpaceae), Botanical Journal of the Linnean Society. pp. 293-304.

Bell D., Long D.G., Forrest A.D., Hollingsworth M.L., Blom H.H., Hollingsworth P.M. (2012) DNA barcoding of European Herbertus (Marchantiopsida, Herbertaceae) and the discovery and description of a new species. Mol Ecol Resources 12:36-47

Birky C.W. (1995) Uniparental Inheritance of Mitochondrial and Chloroplast Genes Mechanisms and Evolution. Proceedings of the National Academy of Sciences of the United States of America 92:11331-11338.

Brinegar C. (2009) Assessing Evolution and Biodiversity in Plants at The Molecular Level. Kathmandu University Journal of Science, Engineering and Technology. 5 (II) pp 149 159

Cao C.P., Gailing O., Siregar I., Indrioko S., Finkeldey R. (2006) Genetic variation at AFLPs for the Dipterocarpaceae and its relation to molecular phylogenies and taxonomic subdivisions. Journal of Plant Research 119:553-558

Cawthorn D.-M., Steinman H.A., Corli Witthuhn R. (2011) Establishment of a mitochondrial DNA sequence database for the identification of fish species commercially available in South Africa. Molecular Ecology Resources 11:979-991

Chao K., M. , Zhang L. (2009) Sequence comparison. Theory and Methods. Spinger. 210 pp

Chase M.W., Salamin N., Wilkinson M., Dunwell J.M., Kesanakurthi R.P., Haidar N., Savolainen V. (2005) Land plants and DNA barcodes: short-term and long-term goals. Philosophical Transactions of the Royal Society B-Biological Sciences 360:1889-1895

Cowan R.S., Fay M.F. (2012) Challenges in the DNA Barcoding of Plant Material Plant DNA Fingerprinting and Barcoding. In Methods Mol Biol 862 : 23-33 
Cuenoud P., Savolainen V., Chatrou L.W., Powell M., Grayer R.J., Chase M.W. (2002) Molecular phylogenetics of Caryophyllales based on nuclear 18S rDNA and plastid rbcL, atpB, and matK DNA sequences. American Journal of Botany 89: 132-144

Dayanandan S., Ashton P.S., Williams S.M., Primack R.B. (1999) Phylogeny of the tropical tree family Dipterocarpaceae based on nucleotide sequences of the chloroplast rbcL gene. American Journal of Botany 86: 1182-1190

de Vere N., Rich T.C.G., Ford C.R., Trinder S.A., Long C., Moore C.W., Satterthwaite D., Davies H., Allainguillaume J., Ronca S., Tatarinova T., Garbett H., Walker K., Wilkinson M.J. (2012) DNA Barcoding the Native Flowering Plants and Conifers of Wales. PLoS ONE. 7 (6) .e37945

Dick C.W., Webb C.O. (2012) Plant DNA Barcodes, Taxonomic Management, and Species Discovery. In Methods Mol Biol 858: 379-393

Fazekas AJ, Burgess KS, Kesanakurti PR et al (2008) Multiple multilocus DNA barcodes from the plastid genome discriminate plant species equally well. PLoS One 3:e2802

Finkeldey R., Leinemann L., Gailing O. (2010) Molecular genetic tools to infer the origin of forest plants and wood. Applied Microbiology and Biotechnology 85: 1251-1258

Gamage D.T., de Silva M.P., Inomata N., Yamazaki T., Szmidt A.E. (2006) Comprehensive molecular phylogeny of the sub-family Dipterocarpoideae (Dipterocarpaceae) based on chloroplast DNA sequences. Genes \& Genetic Systems 81: 1-12

Gemeinholzer B, Christoph Oberprieler, Bachmann K. (2006) Using GenBank Data for Plant Identification: Possibilities and Limitations Using the ITS 1 of Asteraceae Species Belonging to the Tribes Lactuceae and Anthemideae. JSTOR Taxon, Vol. 55. (1): pp. 173-187

Gielly L., Taberlet P. (1994) The Use of Chloroplast DNA to Resolve Plant Phylogenies Noncoding Versus Rbcl Sequences. Molecular Biology and Evolution 11: 769-777

Graham S.W., Olmstead R.G. (2000) Utility of 17 chloroplast genes for inferring the phylogeny of the basal angiosperms. American Journal of Botany 87: 1712-30

Haider N. (2011) Chloroplast-specific universal primers and their uses in plant studies. Biologia Plantarum 55: 225-236

Hajibabaei M., Singer G.A.C., Hebert P.D.N., Hickey D.A. (2007) DNA barcoding: how it complements taxonomy, molecular phylogenetics and population genetics. Trends in Genetics 23: 167-172

Hall B.G. (2011) Phylogenetic Trees Made Easy. A How-to Manual. Fourth edition. Sinauer Associates Inc. Sunderland. $282 \mathrm{pp}$

Hall T.A. (1999) BioEdit: a user-friendly biological sequence alignment editor and analysis program for Windows 95/98/NT. Nucleic Acids Symposium Series 41: 95-98

Hawksworth D.L. ( 1995) Biodiversity: Measurement and Estimation. Chapman and Hall. London 
Hebert P.D.N., Cywinska A., Ball S.L., deWaard J.R. (2003) Biological identifications through DNA barcodes. Proceedings of the Royal Society B: Biological Sciences 270: $313-321$

Hilu K.W., Borsch T., Muller K., Soltis D.E., Soltis P.S., Savolainen V., Chase M.W., Powell M.P., Alice L.A., Evans R., Sauquet H., Neinhuis C., Slotta T.A.B., Rohwer J.G., Campbell C.S., Chatrou L.W. (2003) Angiosperm phylogeny based on matK sequence information. American Journal of Botany 90: 1758-1776

Hollingsworth P.M. (2011) Refining the DNA barcode for land plants. Proceedings of the National Academy of Sciences of the United States of America 108: 19451-19452

Hollingsworth PM, Graham SW, Little DP (2011) Choosing and Using a Plant DNA Barcode. PLoS ONE 6 (5): e19254

Hollingsworth P.M., Forrest L.L., Spouge J.L., Hajibabaei M., Ratnasingham S., van der Bank M., Chase M.W., Cowan R.S., Erickson D.L., Fazekas A.J., Graham S.W., James K.E., Kim K.J., Kress W.J., Schneider H., van AlphenStahl J., Barrett S.C.H., van den Berg C., Bogarin D., Burgess K.S., Cameron K.M., Carine M., Chacon J., Clark A., Clarkson J.J., Conrad F., Devey D.S., Ford C.S., Hedderson T.A.J., Hollingsworth M.L., Husband B.C., Kelly L.J., Kesanakurti P.R., Kim J.S., Kim Y.D., Lahaye R., Lee H.L., Long D.G., Madrinan S., Maurin O., Meusnier I., Newmaster S.G., Park C.W., Percy D.M., Petersen G., Richardson J.E., Salazar G.A., Savolainen V., Seberg O., Wilkinson M.J., Yi D.K., Little D.P., Grp C.P.W. (2009) A DNA barcode for land plants. Proceedings of the National Academy of Sciences of the United States of America 106: 12794-12797

Humphries E.M., Winker K. (2010) Working through polytomies: auklets revisited. Molecular Phylogenetics and Evolution 54: 88-96

Indrioko S. (2005). Chloroplast DNA variation in Indonesia Dipterocarpacae-phylogenetic, taxonomic and population genetic aspects. $\mathrm{PhD}$ thesis. University of Goettingen. Goettingen

Indrioko S., Gailing O., Finkeldey R. (2006) Molecular phylogeny of Dipterocarpaceae in Indonesia based on chloroplast DNA. Plant Systematics and Evolution 261: 99-115

Ishiyama H. T. Kado M. Iwasaki N. A B Shukor, A. E. Szmidt, and T.Yamazaki. (2003). Nucleotide variation in the GapC region of four species of Shorea and its putative hybrids. Tropics 13: 89-99

IUCN. (2011) IUCN Red List of Threatened Species. Version 2011.1. www.iucnredlist.org.

Johnson L.A., Soltis.D.E. (1994.) MatK DNA sequences and phylogenetic reconstruction in Saxifragaceae sensu stricto. Systematic Botany 19: 143-156

Kajita T., Kamiya K., Nakamura K., Tachida H., Wickneswari R., Tsumura Y., Yoshimaru H., Yamazaki T. (1998) Molecular phylogeny of dipetrocarpaceae in Southeast Asia based on nucleotide sequences of matK, trnL intron, and trnL-trnF intergenic spacer region in chloroplast DNA. Molecular Phylogenetics and Evolution 10: 202-209

Kamiya K., Harada K., Tachida H., Ashton P.S. (2005) Phylogeny of PgiC gene in Shorea and its closely related genera (Dipterocarpaceae), the dominant trees in southeast Asian tropical rain forests. American Journal of Botany 92: 775-788 
Kelchner S.A. (2000) The evolution of non-coding chloroplast DNA and its application in plant systematics. Annals of the Missouri Botanical Garden. 87: 482-498

Kerfeld C. S, Scott K. M. (2011) Using BLAST to teach "E-value-tionary" concepts. PLoS Biol 9 (2): e1001014

Kimura M. (1980 ) A simple method for estimating evolutionary rate of base substitutions through comparative studies of nucleotide sequences. Journal of Molecular Evolution. 16: $111-120$

Kool A., de Boer H.J., Kruger A., Rydberg A., Abbad A., Bjork L., Martin G. (2012) Molecular identification of commercialized medicinal plants in southern Morocco. PLoS One 7:e39459.

Kostermans A.J.G. (1981) Stemonoporus Thw. (Dipterocarpaceae) - a Monograph 1. Bulletin Du Museum National D Histoire Naturelle-Section B Adansonia 3: 321-358

Kreft H., Jetz W. (2010) A framework for delineating biogeographical regions based on species distributions. Journal of Biogeography 37:2029-2053.

Kress W.J. (2005) Use of DNA barcodes to identify flowering plants. Proceedings of the National Academy of Sciences 102: 8369-8374

Kress WJ, Erickson DL (2007) A two-locus global DNA barcode for land plants: the coding rbcL gene complements the non-coding trnH-psbA spacer region. PLoS One 2:e508

Kress W.J., Erickson D.L., Jones F.A., Swenson N.G., Perez R., Sanjur O., Bermingham E. (2009) Plant DNA barcodes and a community phylogeny of a tropical forest dynamics plot in Panama. Proceedings of the National Academy of Sciences 106:18621-18626

Lawton J.H., and , May R.M. (1995) Extinction rates. Oxford University Press, London

Lemey P., Salemi M., Vandamme A.M. (2009) The Phylogenetic Handbook. A Practical Approach to Phylogenetic Analysis and Hypothesis Testing. Cambridge University Press. 723 pp

Li Q.-M., He T.-H., Xu Z.-F. (2004) Generic Relationships of Parashorea chinensis Wang Hsie (Dipterocarpaceae) Based on cpDNA Sequences. Taxon 53: 461-466

Little D.P., Stevenson D.W. (2007) A comparison of algorithms for the identification of specimens using DNA barcodes: examples from gymnosperms. Cladistics 23: 1-21

Little D.P. (2011) DNA Barcode Sequence Identification Incorporating Taxonomic Hierarchy and within Taxon Variability. PLoS ONE 6: e20552

McLennan D.A. (2010) How to Read a Phylogenetic Tree. Evo Edu Outreach 3:506-519.

Madden T. (2002) The BLAST Sequence Analysis Tool. In: McEntyre J, Ostell J, editors. The NCBI Handbook [Internet]. Bethesda (MD): National Center for Biotechnology Information (US)

Maury - Lechon G. (1979) Systematic and Phylogenetic Interest of Juvenile Characters (Germination, Mature Embryo, Seedlings) in Dipterocarpaceae. Bulletin De La Societe Botanique De France-Actualites Botaniques 126: 13-21 
Maury G., Muller J., Lugardon B. (1975) Notes on Morphology and Fine-Structure of Exine of Some Pollen Types in Dipterocarpaceae. Review of Palaeobotany and Palynology 19: $241-289$

Maury L.,G., Curtet L. (1998) Biogeography and evolutionay systematics of family Dipterocarpaceae. In Areview of Dipterocarps, taxonomy, ecology and silviculture (eds. S. Appanah and J,M. Turnbull). Center for forest research Institute, Malaysia. pp $5-44$

Mayo S.J., Allkin,R., Baker,W, Blagoderov, V., Brake, I., Clark,B., Govaerts,R., Godfray,C, Haigh A., Hand,R., Harman,K., Jackson,M., Kilian, N., Kirkup,D.W., Kitching,I., Knapp,I, Lewis G.P., Malcolm,P., Raab-Straube, E.von., Roberts, D.M., Scoble,M., Simpson,D.A., Smith,C., Smith V., Villalba,S., Walley,L., \& Wilkin,P. (2008) Alpha e-taxonomy responses from the systematics community. Kew Bulletin 63: 1-16

Meijer W. and Wood, G.H.S. (1964). Dipterocarps of Sabah. Pp. 110-112. Sabah Forest Record No. 5. Forest Departement Sabah. Sandakan. 344.pp

Meijer W. \& Wood G. H. S. (1976) Keys to Dipterocarps of Sabah. BIOTROP, Bogor

Meijer W. (1979) Taxonomic studies in the genus Dipterocarpus. In G. Maury - Lechon (ed). Dipterocarpacees:Taxonomie Phylogenie-Ecologie, Memoires du Museum National d'Histoire Naturelle. Botanique 26: 50 - 56

Meyer C.P., Paulay G. (2005) DNA barcoding: error rates based on comprehensive sampling. PLoS Biol 3: e422

Mora C., Tittensor D.P., Adl S., Simpson A.G.B., Worm B. (2011) How Many Species Are There on Earth and in the Ocean? PLoS Biol 9:e1001127

Morton C. M, Dayanandan S, Dissanayake D. (1999). Phylogeny and biosystematics of Pseudomonotes (Dipterocarpaceae) based on molecular and morphological data. Plant Systematics and Evolution 212: 197-205

Mount D.W. (2007a) Steps Used by the BLAST Algorithm. Cold Spring Harbor Protocols

Mount D.W. (2007b) Using the Basic Local Alignment Search Tool (BLAST). Cold Spring Harbor Protocols

Muller K., Borsch a.T. (2005) Phylogenetics of Utricularia (Lentibulariaceae) and molecular evolution of the trnK intron in a lineage with high substitutional rates. Plant Syst. Evol 250:39-67

Nguyen P.N. (2009). Molecular Phylogeny of Southeast-Asian Dipterocarps belonging to tribe Dipterocarpaceae (Family Dipterocarpaceae) based on Non-Coding Sequence Data of Chloroplast and Nuclear DNA. PhD thesis. University of Goettingen. Goettingen

Nuroniah H.S. (2009). Diagnostic markers for the identification of the tree species Shorea leprosula Miq. and S. parvifolia Dyer and the geographic origin of S. leprosula Miq. $\mathrm{PhD}$ thesis. University of Goettingen. Goettingen

Nuroniah H.S., Gailing O., Finkeldey R. (2010) Development of SCAR Markers for Species Identification in the Genus Shorea (Dipterocarpaceae). Silvae Genetica 59:249-257. 
Oginuma K., Kono Y., and Tobe H. (1999) Embryology of Vateriopsis (Dipterocarpaceae) and relationship of the family. In: Abstract for the XVI International Botanical Congress,http://www.biologie.unihamburg.de/bonline/ibc99/ibc/abstarct/listen/abstracts /3183.html.in Gamage, D. T., de Silva, M. P., Inomata, N., Yamazaki, T., \& Szmidt, A. E. (2006). Comprehensive molecular phylogeny of the sub-family Dipterocarpoideae (Dipterocarpaceae) based on chloroplast DNA sequences. Genes \& Genetic Systems, 81(1): $1-12$

Olmstead, R. G., and Palmer, J. D. (1994). Chloroplast DNA systematics: a review of methods and data analysis. American Journal of Botany 81:1205-1224.

Parameswaran and Gottwald H. (1979) Problematic taxa in the Dipterocarpaceae. Their anatomy and taxonomy. In: Dipterocarpacees, Taxonomie-Phylogenie-Ecologie, 14 -17 Juin 1977. Paris First International Round Table on Dipterocarpaceae. Maury - Lechon G. (ed). Memoires du Museum National d'Histoire Naturelle, Serie B. Botanique 26: 69 $-75$

Pons J. (2006) DNA-based identification of preys from non-destructive, total DNA extractions of predators using arthropod universal primers. Molecular Ecology Notes $6: 623-626$

Rachmayanti Y, Leinemann L, Gailing O, Finkeldey R. (2009) Extraction, amplification and characterization of wood DNA from Dipterocarpaceae. Plant Molecular and Biology Report. 24: 45-55

Rath P., Rajaseger G., Goh C.J., Kumar P.P. (1998) Phylogenetic Analysis of Dipterocarps Using random Amplified Polymorphic DNA Markers. Annals of Botany 82: 61-65

Ratnasingham S., Hebert P.D. (2007) Bold: The Barcode of Life Data System (http://www.barcodinglife.org). Molecular Ecology Notes 7: 355-364

Raubeson, L. A., and Jansen R. K. (2005).Chloroplast genomes of plants. pp. 45-68. In R.Henry,ed. Diversity and evolution of plants-genotypic and phenotypic variation in higher plants. CABI Publishing. Oxfordshire. UnitedKingdom

Ridgway K . P., Duck J. M and Young J. P. W. (2003). Identification of roots from grass swards using PCR-RFLP and FFLP of the plastid trnL (UAA) intron. BMC Ecology $3: 8$

Roy S., Tyagi A., Shukla V., Kumar A., Singh U.M., Chaudhary L.B., Datt B., Bag S.K., Singh P.K., Nair N.K., Husain T., Tuli R. (2010) Universal Plant DNA Barcode Loci May Not Work in Complex Groups: A Case Study with Indian Berberis Species. PLoS ONE 5: e13674

Sambrook J, Fritsch EF, Maniatis T (1989) Molecular cloning: a laboratory manual. 2nd ed. Cold Spring Harbor N.Y., Cold Spring Harbor Laboratory

Sanger F., Nicklen S., Coulson A.R. (1977) DNA sequencing with chain-terminating inhibitors. Proc Natl Acad Sci U S A 74: 5463-7

Schuh R. T. 2000. Biological Systematics: Principles and Applications. Cornell University Press, Ithaca. $236 \mathrm{pp}$

Shaw J. (2007) A molecular phylogenetic approach to the evolution of bryophytes. Bryologist 110: $178-178$ 
Shaw J., Lickey E.B., Beck J.T., Farmer S.B., Liu W., Miller J., Siripun K.C., Winder C.T., Schilling E.E., Small R.L. (2005) The tortoise and the hare II: relative utility of 21 noncoding chloroplast DNA sequences for phylogenetic analysis. American Journal Botany 92: 142-66

Simpson, M.G. (2006). Plant Systematics. 1st editon. Elsevier-Academic Press. 590 pp

Singh G. (2004) Plant systematics: an integrated approach. Plants Systematics: An Integrated Approach. Enfield, N.H: Science Publishers

Soltis D.E., Soltis P.S. (2000) Contributions of plant molecular systematics to studies of molecular evolution. Plant Molecular Biology 42: 45-75

Soltis D.E., Soltis P.S. (2003) The role of phylogenetics in comparative genetics. Plant Physiol 132: 1790-800

Soltis P.S., Soltis D.E., Doyle J.J. (1998) Choosing an approach and an appropriate gene for phylogenetic analysis. D. E. Soltis, P. S. Soltis, and J. J. Doyle, eds. Molecular Systematics of Plants II. DNA Sequencing. pp 1-42

Stuessy T.F. (2008) Plant Taxonomy. The systematic Evaluation of Comparative data. Columbia Univeristy Press. 539 pp

Sun X.-Q., Zhu Y.-J., Guo J.-L., Peng B., Bai M.-M., Hang Y.-Y. (2012) DNA Barcoding the Dioscorea in China, a Vital Group in the Evolution of Monocotyledon: Use of matK Gene for Species Discrimination. PLoS ONE 7: e32057

Suzuki E., and Ashton P.S. (1996). Sepal and nut size ratio of fruits of Asian Dipterocarpaceae and its implications for dispersal. Journal of Tropical Ecology, 12, pp 853-870

Symington C.F. (1943) Forester's Manual of Dipterocarps. Malayan forester records no 16. Penerbit Universiti Malaysia. Kuala Lumpur

Taberlet P., Gielly L., Pautou G., Bouvet J. (1991) Universal primers for amplification of three non-coding regions of chloroplast DNA. Plant Mol Biol 17: 1105-9

Taberlet P., Coissac E., Pompanon F., Gielly L., Miquel C., Valentini A., Vermat T., Corthier G., Brochmann C., Willerslev E. (2007) Power and limitations of the chloroplast trnL (UAA) intron for plant DNA barcoding. Nucleic Acids Research 35: e14-e14

Tamura K., Peterson D., Peterson N., Stecher G., Nei M., Kumar S. (2011) MEGA5: Molecular Evolutionary Genetics Analysis Using Maximum Likelihood, Evolutionary Distance, and Maximum Parsimony Methods. Molecular Biology and Evolution 28:2731-2739

Tautz D., Arctander P., Minelli A., Thomas R.H., Vogler A.P. (2003) A plea for DNA taxonomy. Trends in Ecology \& Evolution 18: 70-74

Thompson D.J., Desmond G.H.,Toby J.G. (1994) CLUSTAL W: improving the sensitivity of progressive multiple sequence alignment through sequence weighting, position-specific gap penalties and weight matrix choice. Nucleic Acids Research, 22: 4673-4680

Tnah L.H., Lee S.L., Ng K.K.S., Faridah Q.Z., Faridah-Hanum I. (2010) Highly Variable Str Markers of Neobalanocarpus Heimii (Dipterocarpaceae) for Forensic DNA Profiling. Journal of Tropical Forest Science 22: 214-226 
Tsumura Y., Kawahara T., Wickneswari R., Yoshimura K. (1996) Molecular phylogeny of Dipterocarpaceae in Southeast Asia using RFLP of PCR-amplified chloroplast genes. Theoretical and Applied Genetics 93: 22-29

Tsumura Y., Kado T., Yoshida K., Abe H., Ohtani M., Taguchi Y., Fukue Y., Tani N., Ueno S., Yoshimura K., Kamiya K., Harada K., Takeuchi Y., Diway B., Finkeldey R., Na'iem M., Indrioko S., Ng K.K.S., Muhammad N., Lee S.L. (2011) Molecular database for classifying Shorea species (Dipterocarpaceae) and techniques for checking the legitimacy of timber and wood products. Journal of Plant Research 124: 35-48

Vijayan K., Tsou C.H. (2010) DNA barcoding in plants: taxonomy in a new perspective. Current Science 99: 1530-1541

Wesselink M., Kuiper I. (2008) Species identification of botanical trace evidence using molecular markers. Forensic Science International: Genetics Supplement Series 1:630632

Wiley E.O., Lieberman B.S. (2011) Phylogenetics.Theory and Practice of Phylogenetic Systematics ( $2^{\text {nd }}$ ed $) .424$ pp. John Wiley and Sons. New York etc.

Whitmore T. C. (1962). Studies in systematic bark morphology. III. Bark taxonomy in Dipterocarpaceae. Gardens Bulletin, Singapore 19: 321-371

Yu J., Xue J.H., Zhou S.L. (2011) New universal matK primers for DNA barcoding angiosperms. Journal of Systematics and Evolution 49:176-181

Yulita K.S., Bayer R.J., West J.G. (2005) Molecular phylogenetic study of Hopea and Shorea (Dipterocarpaceae): Evidence from the trnL-trnF and internal transcribed spacer regions. Plant Species Biology 20:167-182

Zhang C.Y., Wang F.Y., Yan H.F., Hao G., Hu C.M., Ge X.J. (2012) Testing DNA barcoding in closely related groups of Lysimachia L. (Myrsinaceae). Molecular Ecology Resources 12: 98-108

Zhou Y., Lu C., Wu Q. J., Wang Y., Sun Z.T., Deng J.C., Zhang Y. (2008) GISSD: Group I Intron Sequence and Structure Database. Nucleic Acids Resources 36: D31-D37

Zhu W., Liao B., Li R. F. (2010) A Method for Constructing Phylogenetic Tree Based on a Dissimilarity Matrix. Match-Communications in Mathematical and in Computer Chemistry 63: 483-492

Ziegenhagen B., Fladung M. (1997) Variation in the psbC gene region of gymnosperms and angiosperms as detected ky a single restriction site polymorphism. Theoretical and Applied Genetics 94: 1065-1071

Zulkifli J., F., Ariffin N., A., Sherif S., MD. (2012) Molecular Characteristic of Partial Cytochrome Oxidase Subunit $1(\mathrm{CO} 1)$ on Tenualosa toli from Sarawak.In UMT $11^{\text {th }}$ International Annual Symposium on Sustainability Science and Management $09^{\text {th }}-11^{\text {th }}$ July 2012, Terengganu, Malaysia

Zurawski G., Perrot B, Bottomley W, Whitfeld W. (1981) The structure of the gene for the large subunit of ribulose 1,5-bisphosphate carboxylase from spinach chloroplast. NucleicAcids Res 9:3252-3270 


\section{Appendices}

Appendix 1. List of plant species and corresponding GenBank accession numbers retrieved from the database for trnL intron

\begin{tabular}{|c|c|c|c|}
\hline No & $\begin{array}{c}\text { GeneBank } \\
\text { identifier no }\end{array}$ & $\begin{array}{c}\text { Accession } \\
\text { number }\end{array}$ & Species \\
\hline 1 & gi 226236582 & AB451982 & Shorea acuminata \\
\hline 2 & gi 226236585 & AB451979 & Shorea acuminata \\
\hline 3 & gi 226236578 & AB451986 & Shorea acuminatissima \\
\hline 4 & gi 226236579 & AB451985 & Shorea acuminatissima \\
\hline 5 & gi 226236580 & AB451984 & Shorea acuminatissima \\
\hline 6 & gi 226236572 & AB451988 & Shorea acuta \\
\hline 7 & gi 226236573 & AB451987 & Shorea acuta \\
\hline 8 & gi 226236577 & AB451990 & Shorea acuta \\
\hline 9 & gi 226236575 & AB451992 & Shorea agami \\
\hline 10 & gi 226236576 & AB451991 & Shorea agami \\
\hline 11 & gi 208609662 & AB458531 & Shorea albida \\
\hline 12 & gi 208609666 & AB458535 & Shorea albida \\
\hline 13 & gi 226236542 & AB451994 & Shorea almon \\
\hline 14 & gi 226236543 & AB451995 & Shorea almon \\
\hline 15 & gi 226236545 & AB451997 & Shorea amplexicaulis \\
\hline 16 & gi 226236546 & AB451998 & Shorea amplexicaulis \\
\hline 17 & gi 226236547 & AB451999 & Shorea andulensis \\
\hline 18 & gi 226236548 & AB452000 & Shorea argentifolia \\
\hline 19 & gi 226236549 & AB452001 & Shorea assamica \\
\hline 20 & gi 226236550 & AB452002 & Shorea assamica \\
\hline 21 & gi 226236551 & AB452003 & Shorea assamica \\
\hline
\end{tabular}

\begin{tabular}{|c|c|c|c|}
\hline No & $\begin{array}{c}\text { GeneBank } \\
\text { identifier no }\end{array}$ & $\begin{array}{c}\text { Accession } \\
\text { number }\end{array}$ & Species \\
\hline 33 & gi 226236563 & AB452015 & Shorea confusa \\
\hline 34 & gi 226236564 & AB452016 & Shorea confusa \\
\hline 35 & gi 226236566 & AB452018 & Shorea crassa \\
\hline 36 & gi 226236567 & AB452019 & Shorea curtisii \\
\hline 37 & gi 226236568 & AB452020 & Shorea curtisii \\
\hline 38 & gi 226236569 & AB452021 & Shorea dasyphylla \\
\hline 39 & gi 226236570 & AB452022 & Shorea dasyphylla \\
\hline 40 & gi 226236612 & AB452023 & Shorea domatiosa \\
\hline 41 & gi 22034068 & AY026548 & Shorea exelliptica \\
\hline 42 & gi 22034069 & AY026549 & Shorea faguetiana \\
\hline 43 & gi 226236613 & AB452024 & Shorea faguetiana \\
\hline 44 & gi 226236614 & AB452025 & Shorea faguetiana \\
\hline 45 & gi 226236616 & AB452027 & Shorea faguetioides \\
\hline 46 & gi 226236617 & AB452028 & Shorea falcifera \\
\hline 47 & gi 226236618 & AB452029 & Shorea falciferoides \\
\hline 48 & gi 226236619 & AB452030 & Shorea fallax \\
\hline 49 & gi 226236620 & AB452031 & Shorea fallax \\
\hline 50 & gi 226236622 & AB452033 & Shorea fallax \\
\hline 51 & gi 226236625 & AB452036 & Shorea ferruginea \\
\hline 52 & gi 226236626 & AB452037 & Shorea ferruginea \\
\hline 53 & gi 226236627 & AB452038 & Shorea flaviflora \\
\hline
\end{tabular}




\begin{tabular}{|l|l|l|l|}
\hline 22 & gi 226236552 & AB452004 & Shorea atrinervosa \\
\hline 23 & gi 226236553 & AB452005 & Shorea atrinervosa \\
\hline 24 & gi 22034066 & AY026546 & Shorea balangeran \\
\hline 25 & gi 22034067 & AY026547 & Shorea beccariana \\
\hline 26 & gi 226236554 & AB452006 & Shorea beccariana \\
\hline 27 & gi 226236555 & AB452007 & Shorea biawak \\
\hline 28 & gi 226236556 & AB452008 & Shorea biawak \\
\hline 29 & gi 226236558 & AB452010 & Shorea bracteolata \\
\hline 30 & gi 226236559 & AB452011 & Shorea bracteolata \\
\hline 31 & gi 226236560 & AB452012 & Shorea bullata \\
\hline 32 & gi 226236562 & AB452014 & Shorea collina \\
\hline 65 & gi 226236640 & AB452051 & Shorea isoptera \\
\hline 66 & gi 22034074 & AY026554 & Shorea javanica \\
\hline 67 & gi 226236641 & AB452052 & Shorea javanica \\
\hline 68 & gi 226236642 & AB452053 & Shorea johorensis \\
\hline 69 & gi 226236644 & AB452055 & Shorea johorensis \\
\hline 70 & gi 226236645 & AB452056 & Shorea johorensis \\
\hline 71 & gi 22034075 & AY026555 & Shorea johorensis \\
\hline 72 & gi 22034076 & AY026556 & Shorea kunstleri \\
\hline 73 & gi 226236649 & AB452060 & Shorea kunstleri \\
\hline 74 & gi 226236651 & AB452062 & Shorea kunstleri \\
\hline 75 & gi 22034077 & AY026557 & Shorea laevis \\
\hline 76 & gi 226236652 & AB452063 & Shorea laevis \\
\hline 77 & gi 226236653 & AB452064 & Shorea laevis \\
\hline 78 & gi 226236655 & AB452066 & Shorea lepidota \\
\hline 79 & gi 22034078 & AY026558 & Shorea leprosula \\
\hline 80 & gi 226236656 & AB452067 & Shorea leprosula \\
\hline 81 & gi 226236657 & AB452068 & Shorea leprosula \\
\hline 82 & gi 226236660 & AB452071 & Shorea leprosula \\
\hline
\end{tabular}

\begin{tabular}{|l|l|l|l|}
\hline 54 & gi 22034070 & AY026550 & Shorea foxworthyi \\
\hline 55 & gi 226236628 & AB452039 & Shorea foxworthyi \\
\hline 56 & gi 226236629 & AB452040 & Shorea gibbosa \\
\hline 57 & gi 22034071 & AY026551 & Shorea guiso \\
\hline 58 & gi 226236630 & AB452041 & Shorea guiso \\
\hline 59 & gi 226236631 & AB452042 & Shorea havilandii \\
\hline 60 & gi 226236632 & AB452043 & Shorea havilandii \\
\hline 61 & gi 226236635 & AB452046 & Shorea henryana \\
\hline 62 & gi 22034072 & AY026552 & Shorea hopeifolia \\
\hline 63 & gi 226236639 & AB452050 & Shorea inappendiculata \\
\hline 64 & gi 22034073 & AY026553 & Shorea isoptera \\
\hline 98 & gi 226236678 & AB452089 & Shorea macroptera subsp. sandakanensis \\
\hline 99 & gi 22034081 & AY026561 & Shorea materialis \\
\hline 100 & gi 226236679 & AB452090 & Shorea materialis \\
\hline 101 & gi 226236680 & AB452091 & Shorea materialis \\
\hline 102 & gi 22034082 & AY026562 & Shorea maxima \\
\hline 103 & gi 226236682 & AB452093 & Shorea maxima \\
\hline 104 & gi 226236683 & AB452094 & Shorea maxima \\
\hline 105 & gi 22034083 & AY026563 & Shorea maxwelliana \\
\hline 106 & gi 226236684 & AB452095 & Shorea maxwelliana \\
\hline 107 & gi 22034084 & AY026564 & Shorea mecistopteryx \\
\hline 108 & gi 226236685 & AB452096 & Shorea mecistopteryx \\
\hline 109 & gi 226236686 & AB452097 & Shorea mecistopteryx \\
\hline 110 & gi 226236687 & AB452098 & Shorea mujongensis \\
\hline 111 & gi 22034085 & AY026565 & Shorea multiflora \\
\hline 112 & gi 226236689 & AB452100 & Shorea obscura \\
\hline 113 & gi 226236690 & AB452101 & Shorea ochracea \\
\hline 114 & gi 226236691 & AB452102 & Shorea ochracea \\
\hline 115 & gi 226236692 & AB452103 & Shorea ochracea \\
\hline
\end{tabular}




\begin{tabular}{|c|l|l|l|}
\hline 83 & gi 226236661 & AB452072 & Shorea longiflora \\
\hline 84 & gi 226236662 & AB452073 & Shorea longiflora \\
\hline 85 & gi 22034079 & AY026559 & Shorea longisperma \\
\hline 86 & gi 226236663 & AB452074 & Shorea longisperma \\
\hline 87 & gi 22034080 & AY026560 & Shorea macrophylla \\
\hline 88 & gi 226236668 & AB452079 & Shorea macrophylla \\
\hline 89 & gi 226236670 & AB452081 & Shorea macrophylla \\
\hline 90 & gi 226236673 & AB452084 & Shorea macroptera \\
\hline 91 & gi 226236676 & AB452087 & Shorea macroptera \\
\hline 92 & gi 4210582 & AB006396 & Shorea macroptera \\
\hline 93 & gi 226236664 & AB452075 & Shorea macroptera subsp. baillonii \\
\hline 94 & gi 226236665 & AB452076 & Shorea macroptera subsp. baillonii \\
\hline 95 & gi 226236666 & AB452077 & Shorea macroptera subsp. macropterifolia \\
\hline 96 & gi 226236667 & AB452078 & Shorea macroptera subsp. macropterifolia \\
\hline 97 & gi 226236677 & AB452088 & Shorea macroptera subsp. sandakanensis \\
\hline 131 & gi 226236707 & AB452118 & Shorea parvistipulata \\
\hline 132 & gi 226236708 & AB452119 & Shorea patoiensis \\
\hline 133 & gi 226236709 & AB452120 & Shorea patoiensis \\
\hline 134 & gi 226236712 & AB452123 & Shorea pauciflora \\
\hline 135 & gi 226236713 & AB452124 & Shorea pauciflora \\
\hline 136 & gi 226236714 & AB452125 & Shorea pauciflora \\
\hline 137 & gi 226236716 & AB452127 & Shorea peltata \\
\hline 138 & gi 22034090 & AY026570 & Shorea pilosa \\
\hline 139 & gi 226236717 & AB452128 & Shorea pilosa \\
\hline 140 & gi 226236718 & AB452129 & Shorea pilosa \\
\hline 141 & gi 22034091 & AY026571 & Shorea pinanga \\
\hline 142 & gi 226236720 & AB452131 & Shorea pinanga \\
\hline 143 & gi 226236721 & AB452132 & Shorea platycarpa \\
\hline 144 & gi 226236722 & AB452133 & Shorea platyclados \\
\hline & & & \\
\hline 9
\end{tabular}

\begin{tabular}{|l|l|l|l|}
\hline 116 & gi 226236693 & AB452104 & Shorea ochrophloia \\
\hline 117 & gi 22034086 & AY02656 & Shorea ovalis \\
\hline 118 & gi 226236694 & AB452105 & Shorea ovalis \\
\hline 119 & gi 226236695 & AB452106 & Shorea ovalis \\
\hline 120 & gi 4210583 & AB006397 & Shorea ovalis \\
\hline 121 & gi 226236697 & AB452108 & Shorea ovata \\
\hline 122 & gi 22034087 & AY026567 & Shorea palembanica \\
\hline 123 & gi 226236698 & AB452109 & Shorea palembanica \\
\hline 124 & gi 226236699 & AB452110 & Shorea palosapis \\
\hline 125 & gi 22034088 & AY026568 & Shorea parvifolia \\
\hline 126 & gi 226236700 & AB452111 & Shorea parvifolia \\
\hline 127 & gi 226236702 & AB452113 & Shorea parvifolia \\
\hline 128 & gi 226236703 & AB452114 & Shorea parvifolia \\
\hline 129 & gi 22034089 & AY026569 & Shorea parvistipulata \\
\hline 130 & gi 226236706 & AB452117 & Shorea parvistipulata \\
\hline 162 & gi 22034095 & AY026575 & Shorea selanica \\
\hline 163 & gi 22034096 & AY026576 & Shorea seminis \\
\hline 164 & gi 226236739 & AB452150 & Shorea seminis \\
\hline 165 & gi 22034097 & AY026577 & Shorea singkawang \\
\hline 166 & gi 226236740 & AB452151 & Shorea singkawang \\
\hline 167 & gi 226236742 & AB452153 & Shorea singkawang \\
\hline 168 & gi 226236743 & AB452154 & Shorea slootenii \\
\hline 169 & gi 226236744 & AB452155 & Shorea slootenii \\
\hline 170 & gi 226236745 & AB452156 & Shorea slootenii \\
\hline 171 & gi 22034098 & AY026578 & Shorea smithiana \\
\hline 172 & gi 226236746 & AB452157 & Shorea smithiana \\
\hline 173 & gi 226236749 & AB452160 & Shorea smithiana \\
\hline 174 & gi 22034099 & AY026579 & Shorea splendida \\
\hline 175 & gi 226236755 & AB452166 & Shorea splendida \\
\hline
\end{tabular}




\begin{tabular}{|l|l|l|l|}
\hline 145 & gi 226236723 & AB452134 & Shorea platyclados \\
\hline 146 & gi 226236724 & AB452135 & Shorea platyclados \\
\hline 147 & gi 226236725 & AB452136 & Shorea pubistyla \\
\hline 148 & gi 226236726 & AB452137 & Shorea quadrinervis \\
\hline 149 & gi 226236727 & AB452138 & Shorea quadrinervis \\
\hline 150 & gi 226236728 & AB452139 & Shorea quadrinervis \\
\hline 151 & gi 226236729 & AB452140 & Shorea resinosa \\
\hline 152 & gi 22034092 & AY026572 & Shorea richetia \\
\hline 153 & gi 22034093 & AY026573 & Shorea roxburghii \\
\hline 154 & gi 226236730 & AB452141 & Shorea roxburghii \\
\hline 155 & gi 226236733 & AB452144 & Shorea roxburghii \\
\hline 156 & gi 226236734 & AB452145 & Shorea rubra \\
\hline 157 & gi 226236735 & AB452146 & Shorea rubra \\
\hline 158 & gi 226236736 & AB452147 & Shorea rubra \\
\hline 159 & gi 226236737 & AB452148 & Shorea rugosa \\
\hline 160 & gi 22034094 & AY026574 & Shorea scaberrima \\
\hline 161 & gi 226236738 & AB452149 & Shorea scaberrima \\
\hline
\end{tabular}

\begin{tabular}{|l|l|l|l|}
\hline 176 & gi 226236756 & AB452167 & Shorea splendida \\
\hline 177 & gi 22034100 & AY026580 & Shorea stenoptera \\
\hline 178 & gi 226236757 & AB452168 & Shorea stenoptera \\
\hline 179 & gi 226236758 & AB452169 & Shorea stenoptera \\
\hline 180 & gi 226236764 & AB452175 & Shorea sumatrana \\
\hline 181 & gi 226236765 & AB452176 & Shorea sumatrana \\
\hline 182 & gi 226236763 & AB452174 & Shorea sumatrana \\
\hline 183 & gi 226236766 & AB452177 & Shorea superba \\
\hline 184 & gi 226236767 & AB452178 & Shorea superba \\
\hline 185 & gi 226236768 & AB452179 & Shorea superba \\
\hline 186 & gi 226236769 & AB452180 & Shorea symingtonii \\
\hline 187 & gi 226236770 & AB452181 & Shorea teysmanniana \\
\hline 188 & gi 22034101 & AY026581 & Shorea virescens \\
\hline 189 & gi 226236772 & AB452183 & Shorea virescens \\
\hline 190 & gi 226236773 & AB452184 & Shorea virescens \\
\hline 191 & gi 226236775 & AB452186 & Shorea xanthophylla \\
\hline
\end{tabular}


Appendix 1. List of plant species and corresponding GenBank accession numbers retrieved from the database for $p s b C$-trnS IGS

\begin{tabular}{|c|c|c|c|}
\hline No & $\begin{array}{c}\text { GeneBank } \\
\text { Identifier no }\end{array}$ & $\begin{array}{l}\text { Accession } \\
\text { number }\end{array}$ & Species \\
\hline 1 & gi 226237206 & AB452617 & Anisoptera laevis \\
\hline 2 & gi 226237226 & AB452637 & Cotylelobium lanceolatum \\
\hline 3 & gi 226237258 & AB452669 & Hopea dryobalanoides \\
\hline 4 & gi 226237260 & AB452671 & Hopea mengarawan \\
\hline 5 & gi 226237261 & AB452672 & Hopea mengarawan \\
\hline 6 & gi 226237262 & AB452673 & Hopea mengarawan \\
\hline 7 & gi 226237312 & AB452723 & Neobalanocarpus heimii \\
\hline 8 & gi 226237192 & AB452603 & Shorea acuminata \\
\hline 9 & gi 226237193 & AB452604 & Shorea acuminata \\
\hline 10 & gi 226237194 & AB452605 & Shorea acuminata \\
\hline 11 & gi 226237195 & AB452606 & Shorea acuminata \\
\hline 12 & gi 226237196 & AB452607 & Shorea acuminatissima \\
\hline 13 & gi 226237198 & AB452609 & Shorea acuminatissima \\
\hline 14 & gi 226237199 & AB452610 & Shorea acuminatissima \\
\hline 15 & gi 226237197 & AB452608 & Shorea acuminatissima \\
\hline 16 & gi 226237200 & AB452611 & Shorea acuta \\
\hline 17 & gi 226237201 & AB452612 & Shorea acuta \\
\hline 18 & gi 226237202 & AB452613 & Shorea acuta \\
\hline 19 & gi 226237203 & AB452614 & Shorea acuta \\
\hline 20 & gi 226237204 & AB452615 & Shorea agami \\
\hline 21 & gi 226237205 & AB452616 & Shorea agami \\
\hline 22 & gi 208609665 & AB458534 & Shorea albida \\
\hline 23 & gi 208609669 & AB458538 & Shorea albida \\
\hline 24 & gi 226237207 & AB452618 & Shorea almon \\
\hline 25 & gi 226237208 & AB452619 & Shorea almon \\
\hline
\end{tabular}

\begin{tabular}{|c|c|c|c|}
\hline No & $\begin{array}{c}\text { GeneBank } \\
\text { Identifier no }\end{array}$ & $\begin{array}{c}\text { Accession } \\
\text { number }\end{array}$ & Species \\
\hline 37 & gi 226237220 & AB452631 & Shorea biawak \\
\hline 38 & gi 226237221 & AB452632 & Shorea biawak \\
\hline 39 & gi 226237222 & AB452633 & Shorea biawak \\
\hline 40 & gi 226237223 & AB452634 & Shorea bracteolata \\
\hline 41 & gi 226237224 & AB452635 & Shorea bracteolata \\
\hline 42 & gi 226237225 & AB452636 & Shorea bullata \\
\hline 43 & gi 226237227 & AB452638 & Shorea collina \\
\hline 44 & gi 226237228 & AB452639 & Shorea confusa \\
\hline 45 & gi 226237229 & AB452640 & Shorea confusa \\
\hline 46 & gi 226237230 & AB452641 & Shorea confusa \\
\hline 47 & gi 226237231 & AB452642 & Shorea crassa \\
\hline 48 & gi 226237232 & AB452643 & Shorea curtisii \\
\hline 49 & gi 226237233 & AB452644 & Shorea curtisii \\
\hline 50 & gi 226237234 & AB452645 & Shorea dasyphylla \\
\hline 51 & gi 226237235 & AB452646 & Shorea dasyphylla \\
\hline 52 & gi 226237236 & AB452647 & Shorea domatiosa \\
\hline 53 & gi 226237237 & AB452648 & Shorea faguetiana \\
\hline 54 & gi 226237238 & AB452649 & Shorea faguetiana \\
\hline 55 & gi 226237239 & AB452650 & Shorea faguetiana \\
\hline 56 & gi 226237240 & AB452651 & Shorea faguetioides \\
\hline 57 & gi 226237241 & AB452652 & Shorea falcifera \\
\hline 58 & gi 226237242 & AB452653 & Shorea falciferoides \\
\hline 59 & gi 226237243 & AB452654 & Shorea fallax \\
\hline 60 & gi 226237244 & AB452655 & Shorea fallax \\
\hline 61 & gi 226237245 & AB452656 & Shorea fallax \\
\hline
\end{tabular}




\begin{tabular}{|c|c|c|c|}
\hline No & $\begin{array}{c}\text { GeneBank } \\
\text { Identifier no }\end{array}$ & $\begin{array}{l}\text { Accession } \\
\text { number }\end{array}$ & Species \\
\hline 26 & gi 226237209 & AB452620 & Shorea almon \\
\hline 27 & gi 226237210 & AB452621 & Shorea amplexicaulis \\
\hline 28 & gi 226237211 & AB452622 & Shorea amplexicaulis \\
\hline 29 & gi 226237212 & AB452623 & Shorea andulensis \\
\hline 30 & gi 226237213 & AB452624 & Shorea argentifolia \\
\hline 31 & gi 226237214 & AB452625 & Shorea assamica \\
\hline 32 & gi 226237215 & AB452626 & Shorea assamica \\
\hline 33 & gi 226237216 & AB452627 & Shorea assamica \\
\hline 34 & gi 226237217 & AB452628 & Shorea atrinervosa \\
\hline 35 & gi 226237218 & AB452629 & Shorea atrinervosa \\
\hline 36 & gi 226237219 & AB452630 & Shorea beccariana \\
\hline 73 & gi 226237257 & AB452668 & Shorea havilandii \\
\hline 74 & gi 226237259 & AB452670 & Shorea henryana \\
\hline 75 & gi 226237263 & AB452674 & Shorea inappendiculata \\
\hline 76 & gi 226237264 & AB452675 & Shorea isoptera \\
\hline 77 & gi 226237265 & AB452676 & Shorea javanica \\
\hline 78 & gi 226237266 & AB452677 & Shorea johorensis \\
\hline 79 & gi 226237267 & AB452678 & Shorea johorensis \\
\hline 80 & gi 226237268 & AB452679 & Shorea johorensis \\
\hline 81 & gi 226237269 & AB452680 & Shorea johorensis \\
\hline 82 & gi 226237270 & AB452681 & Shorea johorensis \\
\hline 83 & gi 226237271 & AB452682 & Shorea johorensis \\
\hline 84 & gi 226237272 & AB452683 & Shorea johorensis \\
\hline 85 & gi 226237273 & AB452684 & Shorea kunstleri \\
\hline 86 & gi 226237274 & AB452685 & Shorea kunstleri \\
\hline 87 & gi 226237275 & AB452686 & Shorea kunstleri \\
\hline 88 & gi 226237276 & AB452687 & Shorea laevis \\
\hline 89 & gi 226237277 & AB452688 & Shorea laevis \\
\hline 90 & gi 226237278 & AB452689 & Shorea laevis \\
\hline
\end{tabular}

\begin{tabular}{|c|c|c|c|}
\hline No & $\begin{array}{c}\text { GeneBank } \\
\text { Identifier no }\end{array}$ & $\begin{array}{c}\text { Accession } \\
\text { number }\end{array}$ & Species \\
\hline 62 & gi 226237246 & AB452657 & Shorea fallax \\
\hline 63 & gi 226237247 & AB452658 & Shorea fallax \\
\hline 64 & gi 226237248 & AB452659 & Shorea fallax \\
\hline 65 & gi 226237249 & AB452660 & Shorea ferruginea \\
\hline 66 & gi 226237250 & AB452661 & Shorea ferruginea \\
\hline 67 & gi 226237251 & AB452662 & Shorea flaviflora \\
\hline 68 & gi 226237252 & AB452663 & Shorea foxworthyi \\
\hline 69 & gi 226237253 & AB452664 & Shorea gibbosa \\
\hline 70 & gi 226237254 & AB452665 & Shorea guiso \\
\hline 71 & gi 226237255 & AB452666 & Shorea havilandii \\
\hline 72 & gi 226237256 & AB452667 & Shorea havilandii \\
\hline 109 & gi 226237288 & AB452699 & Shorea macroptera subsp. baillonii \\
\hline 110 & gi 226237289 & AB452700 & Shorea macroptera subsp. baillonii \\
\hline 111 & gi 226237290 & AB452701 & Shorea macroptera subsp. macropterifolia \\
\hline 112 & gi 226237291 & AB452702 & Shorea macroptera subsp. macropterifolia \\
\hline 113 & gi 226237301 & AB452712 & Shorea macroptera subsp. sandakanensis \\
\hline 114 & gi 226237302 & AB452713 & Shorea macroptera subsp. sandakanensis \\
\hline 115 & gi 226237304 & AB452715 & Shorea materialis \\
\hline 116 & gi 226237305 & AB452716 & Shorea materialis \\
\hline 117 & gi 226237303 & AB452714 & Shorea materialis \\
\hline 118 & gi 226237306 & AB452717 & Shorea maxima \\
\hline 119 & gi 226237307 & AB452718 & Shorea maxima \\
\hline 120 & gi 226237308 & AB452719 & Shorea maxwelliana \\
\hline 121 & gi 226237309 & AB452720 & Shorea mecistopteryx \\
\hline 122 & gi 226237310 & AB452721 & Shorea mecistopteryx \\
\hline 123 & gi 226237311 & AB452722 & Shorea mujongensis \\
\hline 124 & gi 226237313 & AB452724 & Shorea obscura \\
\hline 125 & gi 226237314 & AB452725 & Shorea ochracea \\
\hline 126 & gi 226237315 & AB452726 & Shorea ochracea \\
\hline
\end{tabular}




\begin{tabular}{|c|c|c|c|}
\hline No & $\begin{array}{c}\text { GeneBank } \\
\text { Identifier no }\end{array}$ & $\begin{array}{l}\text { Accession } \\
\text { number }\end{array}$ & Species \\
\hline 91 & gi 226237279 & AB452690 & Shorea lepidota \\
\hline 92 & gi 226237280 & AB452691 & Shorea leprosula \\
\hline 93 & gi 226237281 & AB452692 & Shorea leprosula \\
\hline 94 & gi 226237282 & AB452693 & Shorea leprosula \\
\hline 95 & gi 226237283 & AB452694 & Shorea leprosula \\
\hline 96 & gi 226237284 & AB452695 & Shorea leprosula \\
\hline 97 & gi 226237285 & AB452696 & Shorea longiflora \\
\hline 98 & gi 226237286 & AB452697 & Shorea longiflora \\
\hline 99 & gi 226237287 & AB452698 & Shorea longisperma \\
\hline 100 & gi 226237292 & AB452703 & Shorea macrophylla \\
\hline 101 & gi 226237293 & AB452704 & Shorea macrophylla \\
\hline 102 & gi 226237294 & AB452705 & Shorea macrophylla \\
\hline 103 & gi 226237295 & AB452706 & Shorea macrophylla \\
\hline 104 & gi 226237296 & AB452707 & Shorea macrophylla \\
\hline 105 & gi 226237297 & AB452708 & Shorea macroptera \\
\hline 106 & gi 226237298 & AB452709 & Shorea macroptera \\
\hline 107 & gi 226237299 & AB452710 & Shorea macroptera \\
\hline 108 & gi 226237300 & AB452711 & Shorea macroptera \\
\hline 145 & gi 226237334 & AB452745 & Shorea patoiensis \\
\hline 146 & gi 226237335 & AB452746 & Shorea patoiensis \\
\hline 147 & gi 226237336 & AB452747 & Shorea pauciflora \\
\hline 148 & gi 226237337 & AB452748 & Shorea pauciflora \\
\hline 149 & gi 226237338 & AB452749 & Shorea pauciflora \\
\hline 150 & gi 226237339 & AB452750 & Shorea pauciflora \\
\hline 151 & gi 226237340 & AB452751 & Shorea peltata \\
\hline 152 & gi 226237341 & AB452752 & Shorea pilosa \\
\hline 153 & gi 226237342 & AB452753 & Shorea pilosa \\
\hline 154 & gi 226237343 & AB452754 & Shorea pilosa \\
\hline 155 & gi 226237344 & AB452755 & Shorea pinanga \\
\hline
\end{tabular}

\begin{tabular}{|c|c|c|c|}
\hline No & $\begin{array}{c}\text { GeneBank } \\
\text { Identifier no }\end{array}$ & $\begin{array}{c}\text { Accession } \\
\text { number }\end{array}$ & Species \\
\hline 127 & gi 226237316 & AB452727 & Shorea ochracea \\
\hline 128 & gi 226237317 & AB452728 & Shorea ochrophloia \\
\hline 129 & gi 226237318 & AB452729 & Shorea ovalis \\
\hline 130 & gi 226237319 & AB452730 & Shorea ovalis \\
\hline 131 & gi 226237320 & AB452731 & Shorea ovalis \\
\hline 132 & gi 226237321 & AB452732 & Shorea ovata \\
\hline 133 & gi 226237322 & AB452733 & Shorea palembanica \\
\hline 134 & gi 226237323 & AB452734 & Shorea palosapis \\
\hline 135 & gi 226237324 & AB452735 & Shorea parvifolia \\
\hline 136 & gi 226237325 & AB452736 & Shorea parvifolia \\
\hline 137 & gi 226237326 & AB452737 & Shorea parvifolia \\
\hline 138 & gi 226237327 & AB452738 & Shorea parvifolia \\
\hline 139 & gi 226237328 & AB452739 & Shorea parvifolia \\
\hline 140 & gi 226237329 & AB452740 & Shorea parvifolia \\
\hline 141 & gi 226237330 & AB452741 & Shorea parvistipulata \\
\hline 142 & gi 226237331 & AB452742 & Shorea parvistipulata \\
\hline 143 & gi 226237332 & AB452743 & Shorea patoiensis \\
\hline 144 & gi 226237333 & AB452744 & Shorea patoiensis \\
\hline 178 & gi 226237367 & AB452778 & Shorea slootenii \\
\hline 179 & gi 226237368 & AB452779 & Shorea slootenii \\
\hline 180 & gi 226237369 & AB452780 & Shorea slootenii \\
\hline 181 & gi 226237376 & AB452787 & Shorea smithiana \\
\hline 182 & gi 226237378 & AB452789 & Shorea smithiana \\
\hline 183 & gi 226237370 & AB452781 & Shorea smithiana \\
\hline 184 & gi 226237371 & AB452782 & Shorea smithiana \\
\hline 185 & gi 226237372 & AB452783 & Shorea smithiana \\
\hline 186 & gi 226237373 & AB452784 & Shorea smithiana \\
\hline 187 & gi 226237374 & AB452785 & Shorea smithiana \\
\hline 188 & gi 226237375 & AB452786 & Shorea smithiana \\
\hline
\end{tabular}




\begin{tabular}{|l|l|l|l|}
\hline No & \multicolumn{1}{|c|}{$\begin{array}{c}\text { GeneBank } \\
\text { Identifier no }\end{array}$} & $\begin{array}{c}\text { Accession } \\
\text { number }\end{array}$ & \multicolumn{1}{|c|}{ Species } \\
\hline 156 & gi 226237345 & AB452756 & Shorea platycarpa \\
\hline 157 & gi 226237346 & AB452757 & Shorea platyclados \\
\hline 158 & gi 226237347 & AB452758 & Shorea platyclados \\
\hline 159 & gi 226237348 & AB452759 & Shorea platyclados \\
\hline 160 & gi 226237349 & AB452760 & Shorea pubistyla \\
\hline 161 & gi 226237350 & AB452761 & Shorea quadrinervis \\
\hline 162 & gi 226237352 & AB452763 & Shorea quadrinervis \\
\hline 163 & gi 226237351 & AB452762 & Shorea quadrinervis \\
\hline 164 & gi 226237353 & AB452764 & Shorea resinosa \\
\hline 165 & gi 226237354 & AB452765 & Shorea roxburghii \\
\hline 166 & gi 226237355 & AB452766 & Shorea roxburghii \\
\hline 167 & gi 226237356 & AB452767 & Shorea roxburghii \\
\hline 168 & gi 226237357 & AB452768 & Shorea roxburghii \\
\hline 169 & gi 226237358 & AB452769 & Shorea rubra \\
\hline 170 & gi 226237359 & AB452770 & Shorea rubra \\
\hline 171 & gi 226237360 & AB452771 & Shorea rubra \\
\hline 172 & gi 226237361 & AB452772 & Shorea rugosa \\
\hline 173 & gi 226237362 & AB452773 & Shorea scaberrima \\
\hline 174 & gi 226237363 & AB452774 & Shorea seminis \\
\hline 175 & gi 226237364 & AB452775 & Shorea singkawang \\
\hline 176 & gi 226237365 & AB452776 & Shorea singkawang \\
\hline 177 & gi 226237366 & AB452777 & Shorea singkawang \\
\hline & & & \\
\hline
\end{tabular}

\begin{tabular}{|l|l|l|l|}
\hline No & $\begin{array}{c}\text { GeneBank } \\
\text { Identifier no }\end{array}$ & $\begin{array}{c}\text { Accession } \\
\text { number }\end{array}$ & \multicolumn{1}{|c|}{ Species } \\
\hline 189 & gi 226237377 & AB452788 & Shorea smithiana \\
\hline 190 & gi 226237379 & AB452790 & Shorea splendida \\
\hline 191 & gi 226237380 & AB452791 & Shorea splendida \\
\hline 192 & gi 226237381 & AB452792 & Shorea stenoptera \\
\hline 193 & gi 226237382 & AB452793 & Shorea stenoptera \\
\hline 194 & gi 226237383 & AB452794 & Shorea stenoptera \\
\hline 195 & gi 226237384 & AB452795 & Shorea stenoptera \\
\hline 196 & gi 226237385 & AB452796 & Shorea stenoptera \\
\hline 197 & gi 226237386 & AB452797 & Shorea stenoptera \\
\hline 198 & gi 226237387 & AB452798 & Shorea sumatrana \\
\hline 199 & gi 226237388 & AB452799 & Shorea sumatrana \\
\hline 200 & gi 226237389 & AB452800 & Shorea sumatrana \\
\hline 201 & gi 226237390 & AB452801 & Shorea superba \\
\hline 202 & gi 226237391 & AB452802 & Shorea superba \\
\hline 203 & gi 226237392 & AB452803 & Shorea superba \\
\hline 204 & gi 226237393 & AB452804 & Shorea symingtonii \\
\hline 205 & gi 226237394 & AB452805 & Shorea teysmanniana \\
\hline 206 & gi 226237396 & AB452807 & Shorea virescens \\
\hline 207 & gi 226237397 & AB452808 & Shorea virescens \\
\hline 208 & gi 226237399 & AB452810 & Shorea xanthophylla \\
\hline 209 & gi 226237395 & AB452806 & Vatica bella \\
\hline 210 & gi 226237398 & AB452809 & Vatica oblongifolia \\
\hline & & & \\
\hline
\end{tabular}


Appendix 1. List of plant species and corresponding GenBank accession numbers retrieved from the database for $r b c \mathrm{~L}$

\begin{tabular}{|c|l|l|l|}
\hline No & $\begin{array}{c}\text { GeneBank } \\
\text { Identifier no }\end{array}$ & $\begin{array}{c}\text { Accession } \\
\text { number }\end{array}$ & \multicolumn{1}{|c|}{ Species } \\
\hline 1 & gi 2897113 & AF030238 & Pseudomonotes tropenbosii \\
\hline 2 & gi 14595085 & AJ247623 & Shorea talura \\
\hline 3 & gi 37790902 & AY328198 & Hopea hainanensis \\
\hline 4 & gi 2654338 & Y15144 & Anisoptera marginata \\
\hline 5 & gi 37790904 & AY328199 & Vatica mangachapoi \\
\hline
\end{tabular}


Appendix 1. List of plant species and corresponding GenBank accession numbers retrieved from the database for matK

\begin{tabular}{|c|c|c|c|}
\hline No & $\begin{array}{c}\text { GeneBank } \\
\text { Identifier no }\end{array}$ & $\begin{array}{c}\text { Accession } \\
\text { no }\end{array}$ & Species \\
\hline 1 & gi 292679842 & AB295878 & Anisoptera laevis \\
\hline 2 & gi 292679844 & AB295879 & Anisoptera marginata \\
\hline 3 & gi 292679846 & AB295880 & Anisoptera oblonga \\
\hline 4 & gi 292679848 & AB295881 & Cotylelobium malayanum \\
\hline 5 & gi 292679850 & AB295882 & Cotylelobium malayanum \\
\hline 6 & gi 292679852 & AB295883 & Cotylelobium scabriusculum \\
\hline 7 & gi 292679854 & AB295884 & Dipterocarpus alatus \\
\hline 8 & gi 292679856 & AB295885 & Dipterocarpus baudii \\
\hline 9 & gi 292679858 & AB295886 & Dipterocarpus cornutus \\
\hline 10 & gi 292679860 & AB295887 & Dipterocarpus glandulosus \\
\hline 11 & gi 292679862 & AB295888 & Dipterocarpus hispidus \\
\hline 12 & gi 292679864 & AB295889 & Dipterocarpus insignis \\
\hline 13 & gi 292679866 & AB295890 & Dipterocarpus kerrii \\
\hline 14 & gi 292679868 & AB295891 & Dipterocarpus palembanicus \\
\hline 15 & gi 292679870 & AB295892 & Dipterocarpus zeylanicus \\
\hline 16 & gi 292679872 & AB295893 & Dryobalanops aromatica \\
\hline 17 & gi 292679874 & AB295894 & Dryobalanops oblongifolia \\
\hline 18 & gi 292679876 & AB295895 & Hopea discolor \\
\hline 19 & gi 292679878 & AB295896 & Hopea helferi \\
\hline 20 & gi 292679880 & AB295897 & Hopea jucunda \\
\hline 21 & gi 292679882 & AB295898 & Hopea jucunda subsp. modesta \\
\hline 22 & gi 292679884 & AB295899 & Hopea latifolia \\
\hline 23 & gi 292679886 & AB295900 & Hopea nervosa \\
\hline 24 & gi 292679888 & AB295901 & Hopea odorata \\
\hline
\end{tabular}

\begin{tabular}{|c|c|c|c|}
\hline No & $\begin{array}{c}\text { GeneBank } \\
\text { Identifier no }\end{array}$ & $\begin{array}{c}\text { Accession } \\
\text { no }\end{array}$ & Species \\
\hline 36 & gi 4210561 & AB006376 & Shorea bullata \\
\hline 37 & gi 4210562 & AB006377 & Shorea bullata \\
\hline 38 & gi 4210563 & AB006378 & Shorea bullata \\
\hline 39 & gi 4210564 & AB006379 & Shorea bullata \\
\hline 40 & gi 4210565 & AB006380 & Shorea bullata \\
\hline 41 & gi 4210566 & AB006381 & Shorea bullata \\
\hline 42 & gi 4210567 & AB006382 & Shorea bullata \\
\hline 43 & gi 4210568 & AB006383 & Shorea bullata \\
\hline 44 & gi 4210570 & AB006384 & Shorea congestiflora \\
\hline 45 & gi 4210571 & AB006385 & Shorea cordifolia \\
\hline 46 & gi 71891362 & AJ581409 & Shorea curtisii \\
\hline 47 & gi 94966499 & AB246414 & Shorea disticha \\
\hline 48 & gi 94966501 & AB246415 & Shorea dyeri \\
\hline 49 & gi 94966503 & AB246416 & Shorea elliptica \\
\hline 50 & gi 94966505 & AB246417 & Shorea fallax \\
\hline 51 & gi 94966507 & AB246418 & Shorea fallax \\
\hline 52 & gi 94966509 & AB246419 & Shorea fallax \\
\hline 53 & gi 94966511 & AB246420 & Shorea fallax \\
\hline 54 & gi 94966513 & AB246421 & Shorea fallax \\
\hline 55 & gi 94966515 & AB246422 & Shorea fallax \\
\hline 56 & gi 94966517 & AB246423 & Shorea fallax \\
\hline 57 & gi 94966519 & AB246424 & Shorea fallax \\
\hline 58 & gi 94966523 & AB246426 & Shorea gardneri \\
\hline 59 & gi 94966525 & AB246427 & Shorea kunstleri \\
\hline
\end{tabular}




\begin{tabular}{|l|l|l|l|}
\hline No & \multicolumn{1}{|c|}{$\begin{array}{c}\text { GeneBank } \\
\text { Identifier no }\end{array}$} & $\begin{array}{c}\text { Accession } \\
\text { no }\end{array}$ & \\
\hline 25 & gi 292679890 & AB295902 & Hopea subalata \\
\hline 26 & gi 292679892 & AB295903 & Hopea wightiana \\
\hline 27 & gi 34597658 & AY305717 & Monotes madagascariensis \\
\hline 28 & gi 34597658 & AY305717 & Neobalanocarpus heimii \\
\hline 29 & gi 34597660 & AY305718 & Parashorea chinensis \\
\hline 30 & gi 4210551 & AB006370 & Parashorea chinensis var. kwangsiensis \\
\hline 31 & gi 4210555 & AB006371 & Parashorea lucida \\
\hline 32 & gi 4210556 & AB006372 & Shorea acuminata \\
\hline 33 & gi 4210558 & AB006373 & Shorea affinis \\
\hline 34 & gi 4210559 & AB006374 & Shorea assamica \\
\hline 35 & gi 4210560 & AB006375 & Shorea bracteolata \\
\hline 71 & gi 94966549 & AB246439 & Shorea multiflora \\
\hline 72 & gi 94966551 & AB246440 & Shorea ovalifolia \\
\hline 73 & gi 94966553 & AB246441 & Shorea ovalis \\
\hline 74 & gi 94966555 & AB246442 & Shorea pallescens \\
\hline 75 & gi 94966557 & AB246443 & Shorea parvifolia \\
\hline 76 & gi 94966559 & AB246444 & Shorea pinanga \\
\hline 77 & gi 94966561 & AB246445 & Shorea quadrinervis \\
\hline 78 & gi 94966563 & AB246446 & Shorea richetia \\
\hline 79 & gi 94966565 & AB246447 & Shorea seminis \\
\hline 80 & gi 94966569 & AB246449 & Shorea smithiana \\
\hline 81 & gi 94966571 & AB246450 & Shorea smithiana \\
\hline 82 & gi 94966573 & AB246451 & Shorea smithiana \\
\hline 83 & gi 94966575 & AB246452 & Shorea smithiana \\
\hline 84 & gi 94966577 & AB246453 & Shorea smithiana \\
\hline 85 & gi 94966579 & AB246454 & Shorea smithiana \\
\hline 86 & gi 94966581 & AB246455 & Shorea splendens \\
\hline
\end{tabular}

\begin{tabular}{|c|l|l|l|}
\hline No & \multicolumn{1}{|c|}{$\begin{array}{c}\text { GeneBank } \\
\text { Identifier no }\end{array}$} & $\begin{array}{c}\text { Accession } \\
\text { no }\end{array}$ & \\
\hline 60 & gi 94966527 & AB246428 & Shorea kunstleri \\
\hline 61 & gi 94966529 & AB246429 & Shorea kunstleri \\
\hline 62 & gi 94966531 & AB246430 & Shorea kunstleri \\
\hline 63 & gi 94966533 & AB246431 & Shorea kunstleri \\
\hline 64 & gi 94966535 & AB246432 & Shorea laevis \\
\hline 65 & gi 94966537 & AB246433 & Shorea leprosula \\
\hline 66 & gi 94966539 & AB246434 & Shorea lissophylla \\
\hline 67 & gi 94966541 & AB246435 & Shorea macrophylla \\
\hline 68 & gi 94966543 & AB246436 & Shorea macroptera \\
\hline 69 & gi 94966545 & AB246437 & Shorea macroptera \\
\hline 70 & gi 94966547 & AB246438 & Shorea megistophylla \\
\hline 91 & gi 94966591 & AB246460 & Shorea zeylanica \\
\hline 92 & gi 94966593 & AB246461 & Stemonoporus acuminatus \\
\hline 93 & gi 94966595 & AB246462 & Stemonoporus bullatus \\
\hline 94 & gi 94966597 & AB246463 & Stemonoporus gilimalensis \\
\hline 95 & gi 94966599 & AB246464 & Stemonoporus kanneliyensis \\
\hline 96 & gi 94966601 & AB246465 & Stemonoporus lancifolius \\
\hline 97 & gi 94966603 & AB246466 & Stemonoporus reticulatus \\
\hline 98 & gi 94966605 & AB246467 & Stemonoporus scalarinervis \\
\hline 99 & gi 94966607 & AB246468 & Stemonoporus wightii \\
\hline 100 & gi 94966609 & AB246469 & Upuna borneensis \\
\hline 101 & gi 94966611 & AB246470 & Vateria copallifera \\
\hline 102 & gi 94966613 & AB246471 & Vateriopsis seychellarum \\
\hline 103 & gi 94966615 & AB246472 & Vatica affinis \\
\hline 104 & gi 94966617 & AB246473 & Vatica bella \\
\hline 105 & gi 94966619 & AB246474 & Vatica chinensis \\
\hline 106 & gi 94966621 & AB246475 & Vatica coriacea \\
\hline
\end{tabular}




\begin{tabular}{|c|l|l|l|}
\hline No & \multicolumn{1}{|c|}{$\begin{array}{c}\text { GeneBank } \\
\text { Identifier no }\end{array}$} & $\begin{array}{c}\text { Accession } \\
\text { no }\end{array}$ & \multicolumn{1}{|c|}{ Species } \\
\hline 87 & gi 94966583 & AB246456 & Shorea stipularis \\
\hline 88 & gi 94966585 & AB246457 & Shorea trapezifolia \\
\hline 89 & gi 94966587 & AB246458 & Shorea worthingtonii \\
\hline 90 & gi 94966589 & AB246459 & Shorea xanthophylla \\
\hline
\end{tabular}

\begin{tabular}{|c|l|l|l|}
\hline No & $\begin{array}{c}\text { GeneBank } \\
\text { Identifier no }\end{array}$ & $\begin{array}{c}\text { Accession } \\
\text { no }\end{array}$ & \multicolumn{1}{|c|}{ Species } \\
\hline 107 & gi 94966623 & AB246476 & Vatica micrantha \\
\hline 108 & gi 94966625 & AB246477 & Vatica odorata \\
\hline 109 & gi 94966627 & AB246478 & Vatica pauciflora \\
\hline
\end{tabular}


Appendix 2. The tree of trnL intron using Maximum Likelihood method based on the Kimura 2-parameter model. The percentage of bootstrap value is shown next to the branches. The analysis involved 145 nucleotide sequences. The number in bracket means number of species tested.

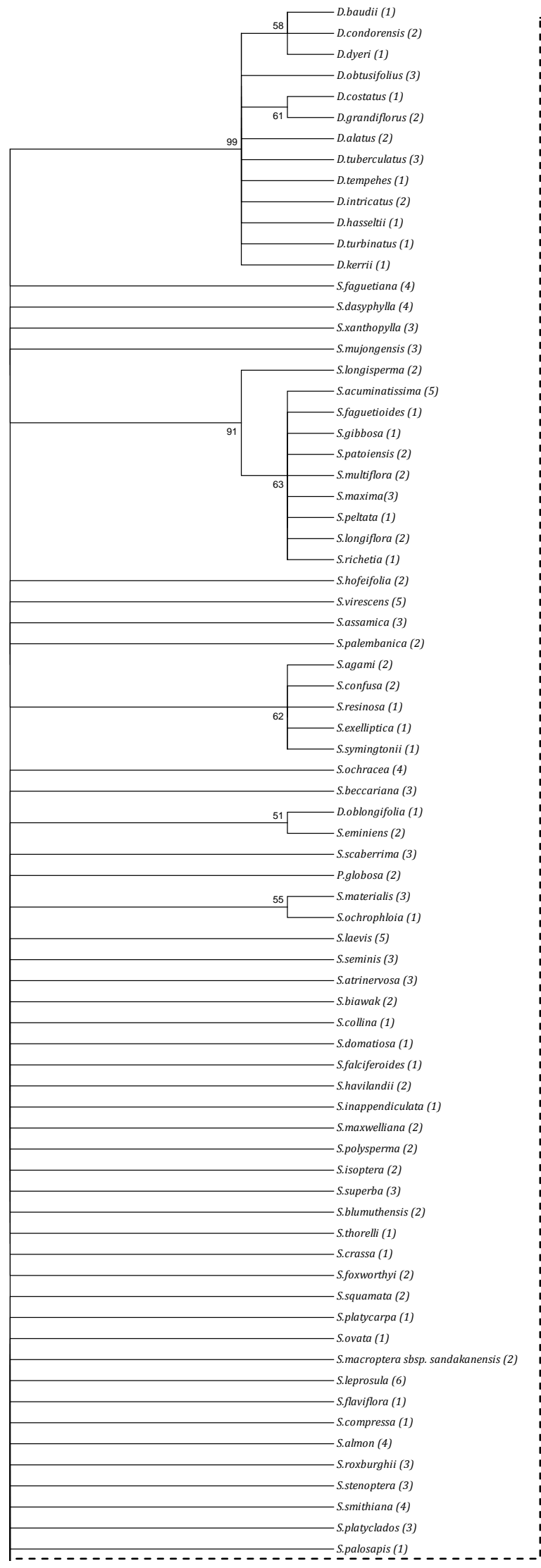

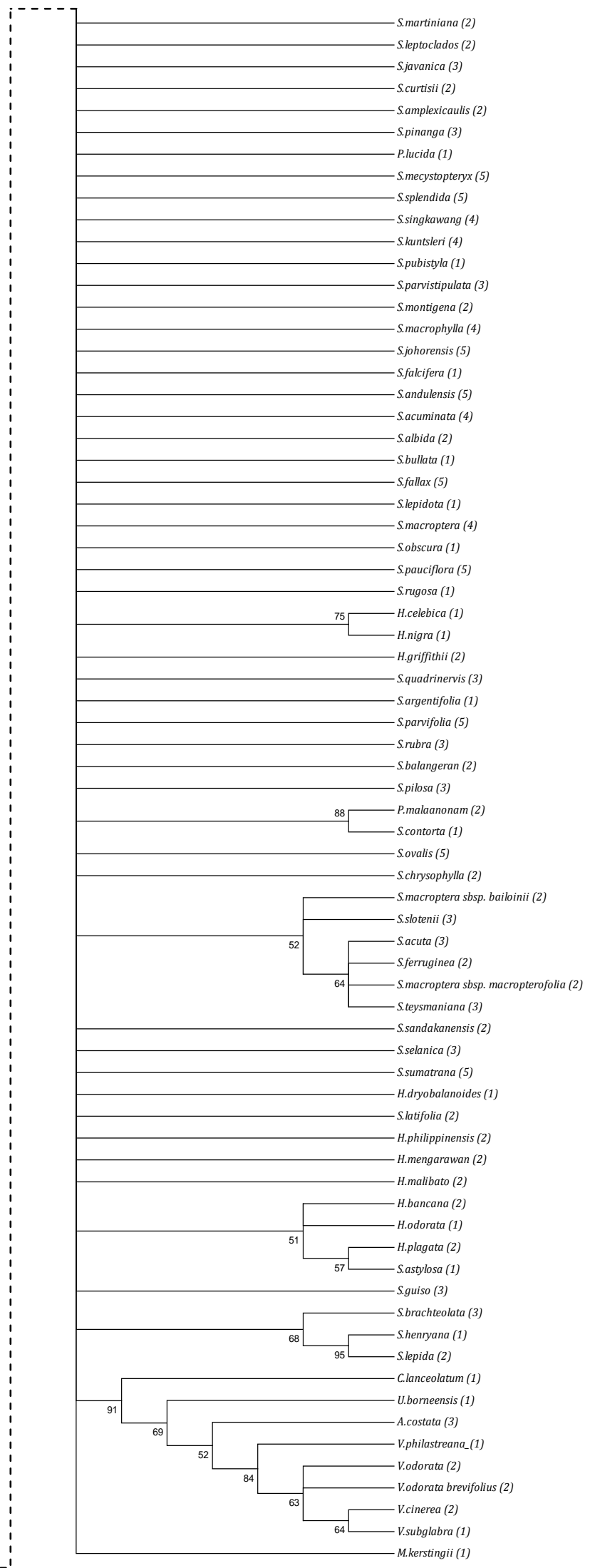


Appendix 3. The tree of trnL intron using the neighbor joining method and using the Kimura 2-parameter for genetic distance. The percentages of the bootstrap test (1000 replicates) are shown next to the branches. The analysis involved 145 nucleotide sequences. The number in bracket means number of species tested.
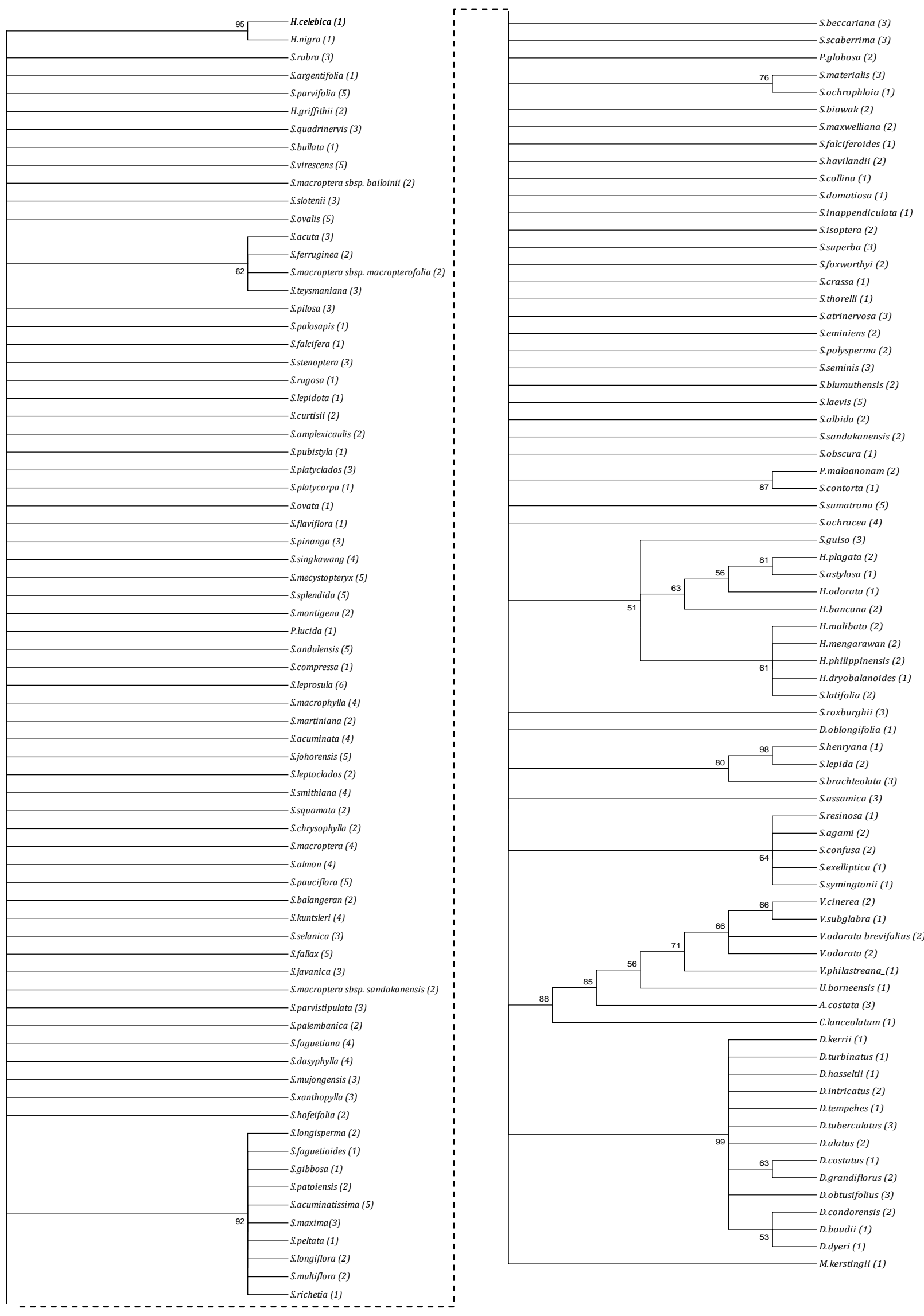
Appendix 4. The tree of psbC-trnS IGS using the maximum likelihood method based on the Kimura 2parameter model. The percentage of the bootstrap value shown next to the branch. There were a total of 1137 positions in the final dataset. The number in parenthesis means number of species tested.
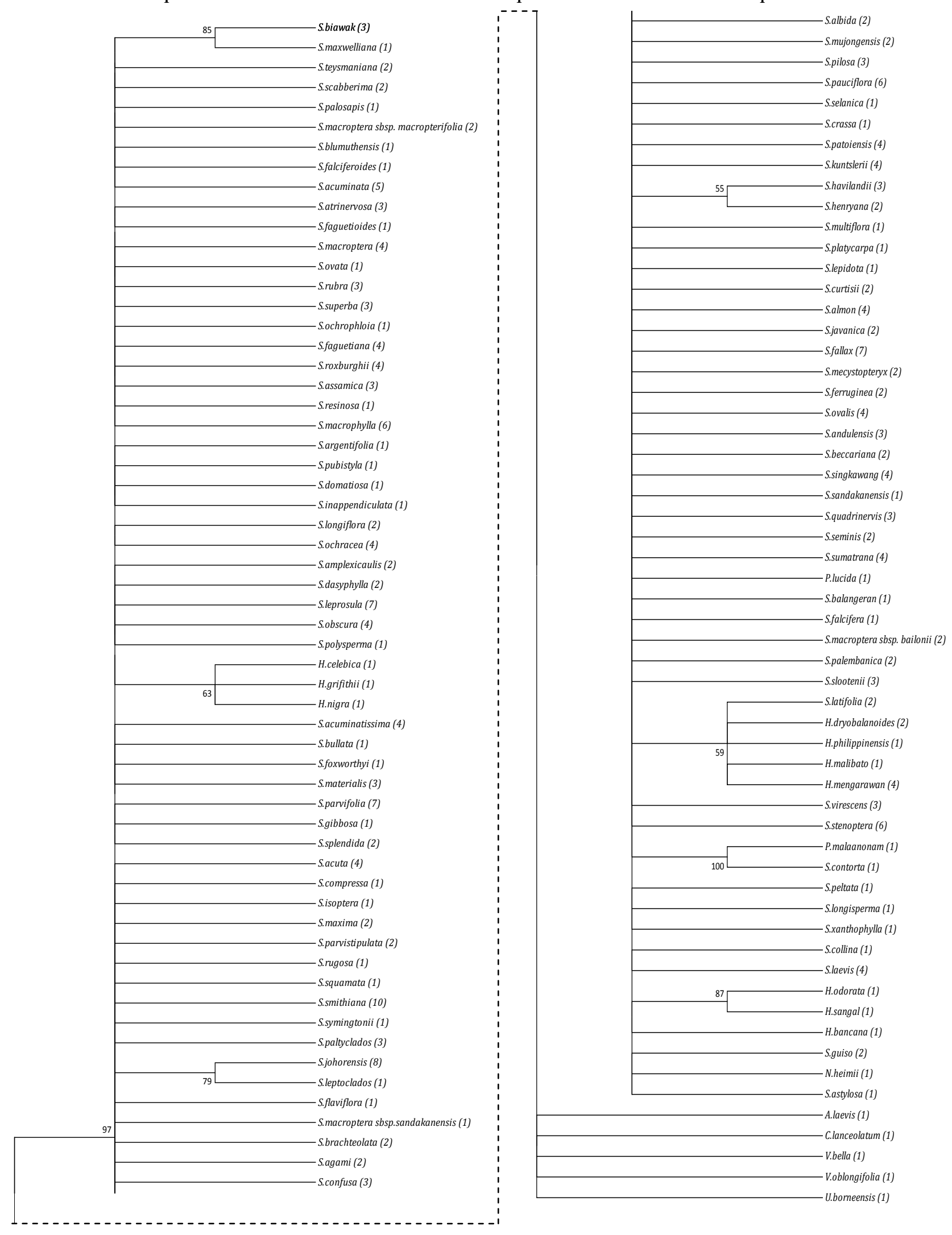
Appendix 5. The psbC-trnS IGS tree using neighbor joining method and Kimura 2-parameter. The percentages of bootstrap value are shown next to the branches. This analysis involved 117 nucleotide sequences and 1137 positions. The number in parentheses means number of species tested.

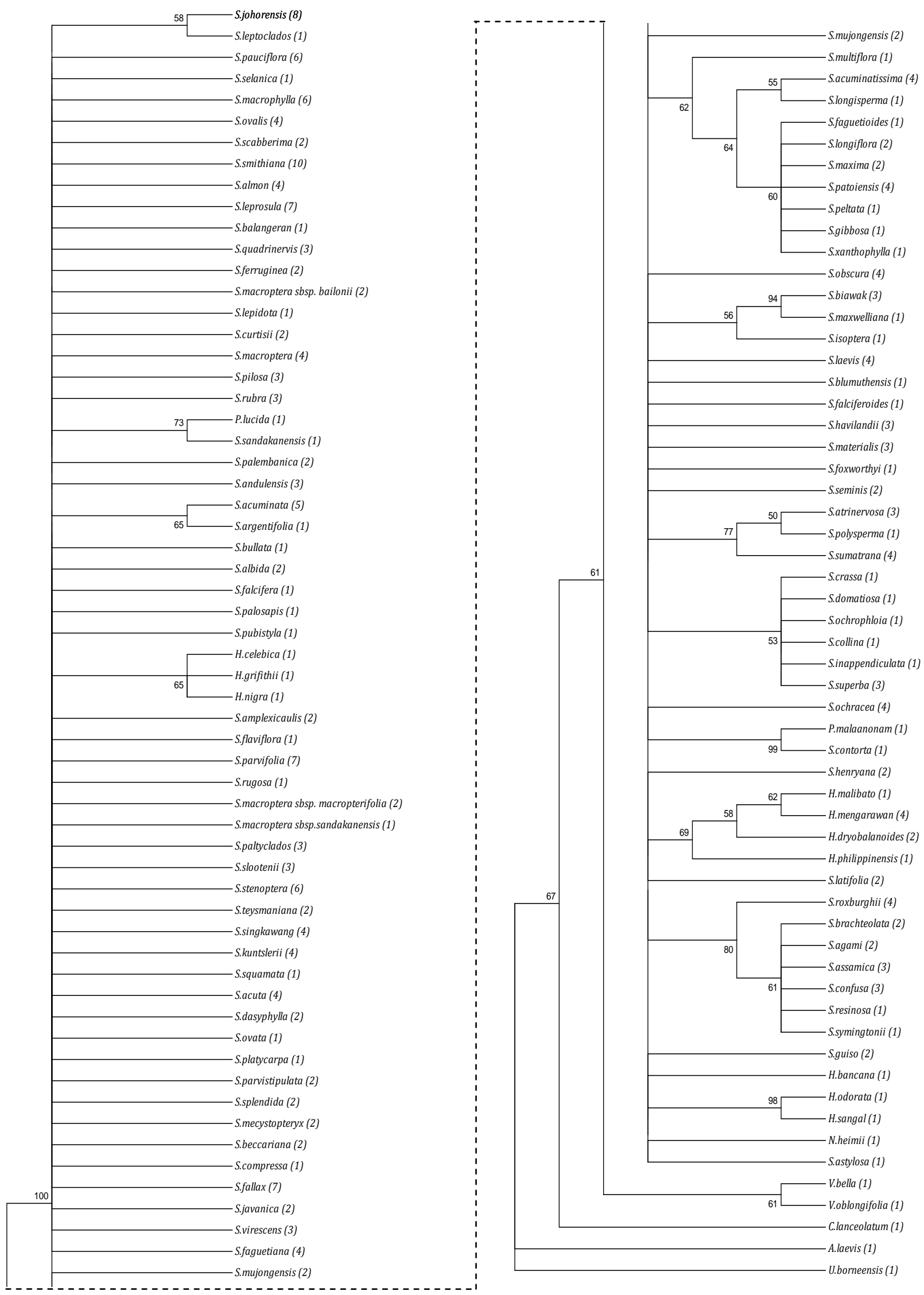


Appendix 6. The tree of matK gene using Maximum Likelihood method based on the Kimura 2-parameter model. The percentage of bootstrap value is shown next to the branches. The analysis involved 116 nucleotide sequences of 635 positions in the final dataset. The number in parentheses means number of species tested.

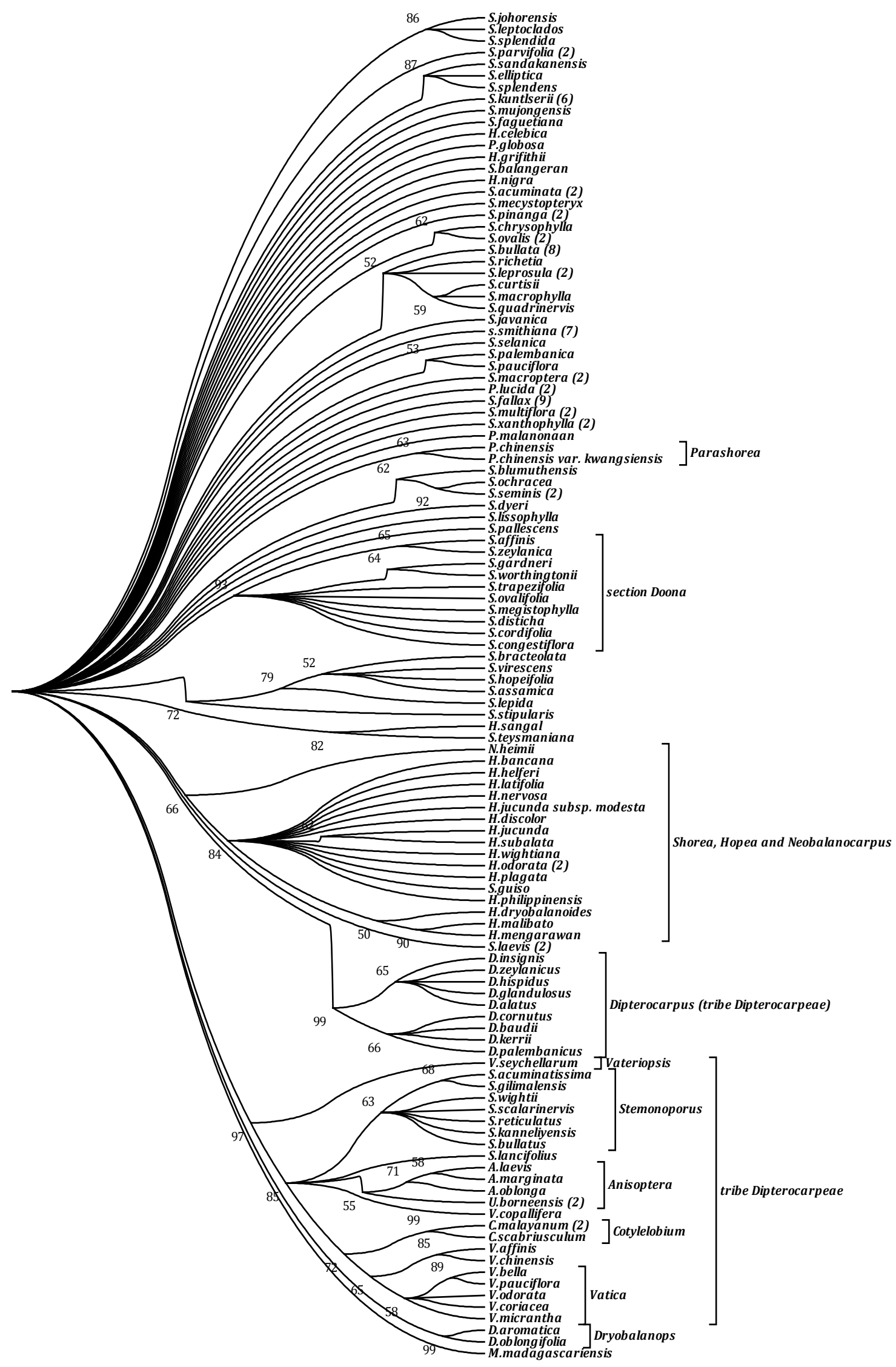


Appendix 7. The tree of matK gene using the neighbor joining method and Kimura 2-parameter. The percentages of bootstrap value are shown next to the branches. The analysis involved 116 nucleotide sequences of 635 positions in the final dataset. The number in parentheses means number of species tested.

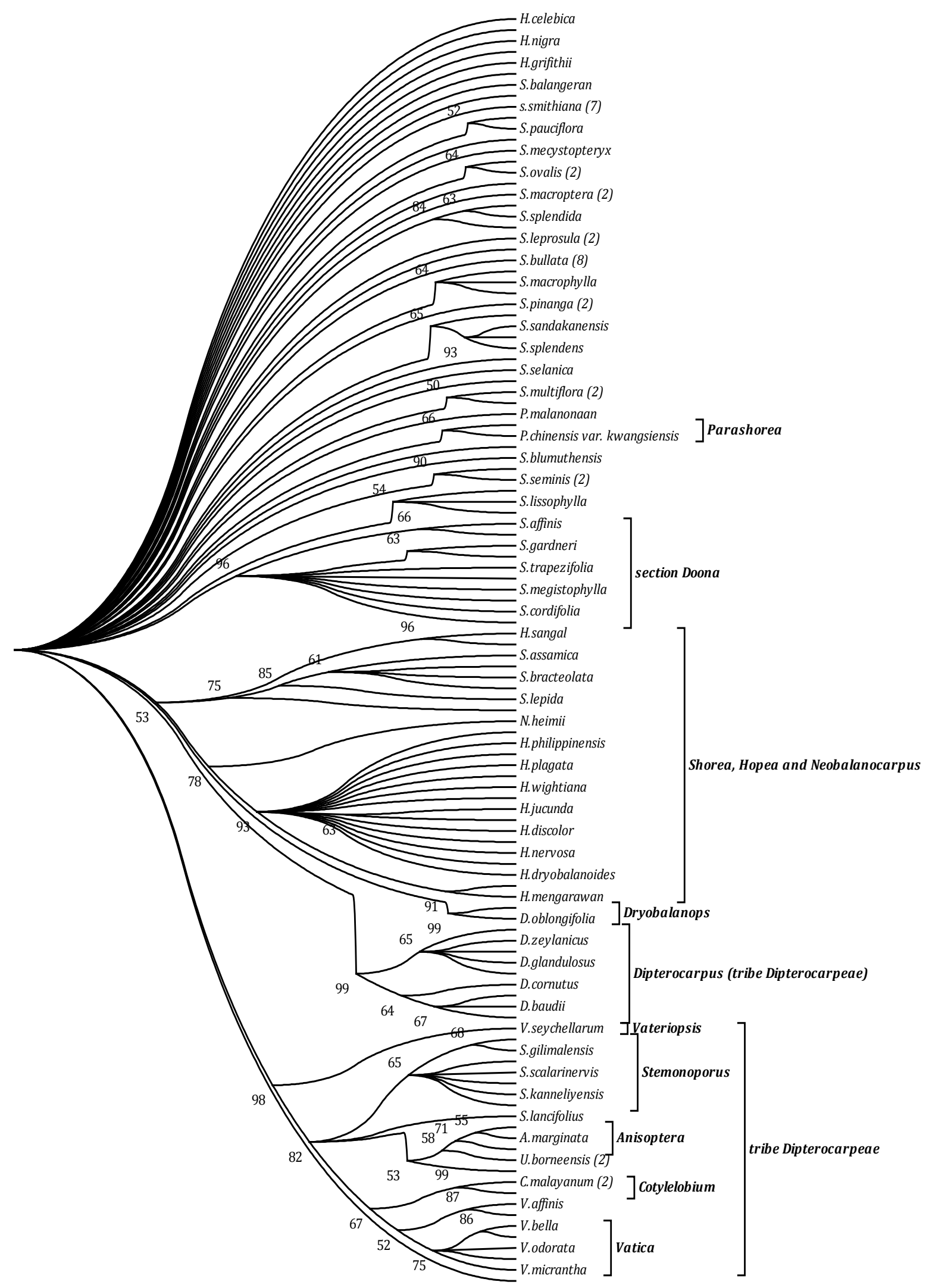


Appendix 8. The tree of $r b c L$ gene using the maximum likelihood method based on the Kimura 2-parameter model. The percentage of bootstrap value is shown next to the branches. The analysis involved 67 nucleotide sequences. There were a total of 647 positions in the final dataset. The number in brackets is the number of species tested.

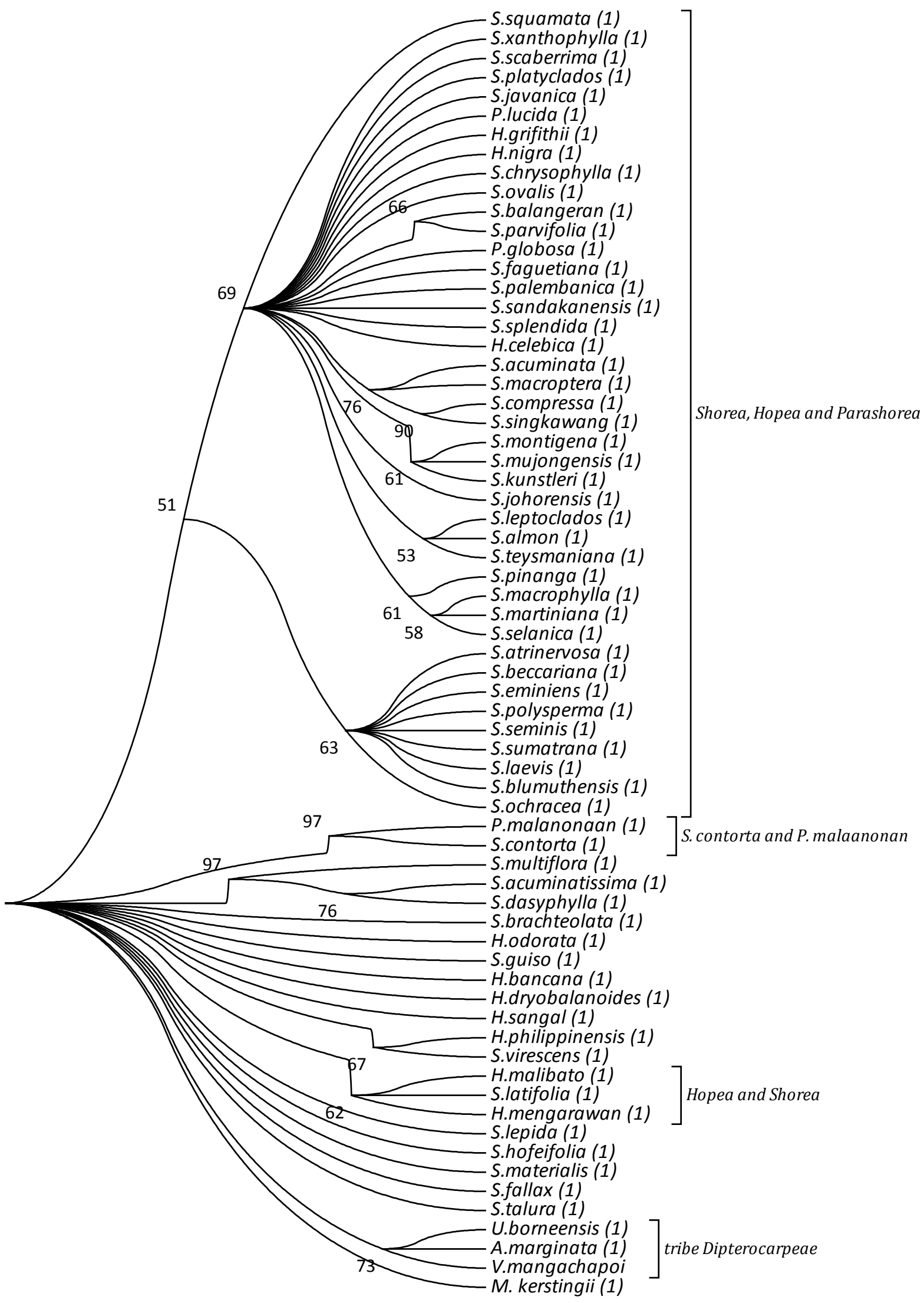


Appendix 9. The tree of $r b c \mathrm{~L}$ gene using the neighbor joining method based on the Kimura 2-parameter. The percentages of bootstrap value are shown next to the branches. The analysis involved 67 nucleotide sequences. There were a total of 647 positions in the final dataset. The number in brackets is the number of species tested.

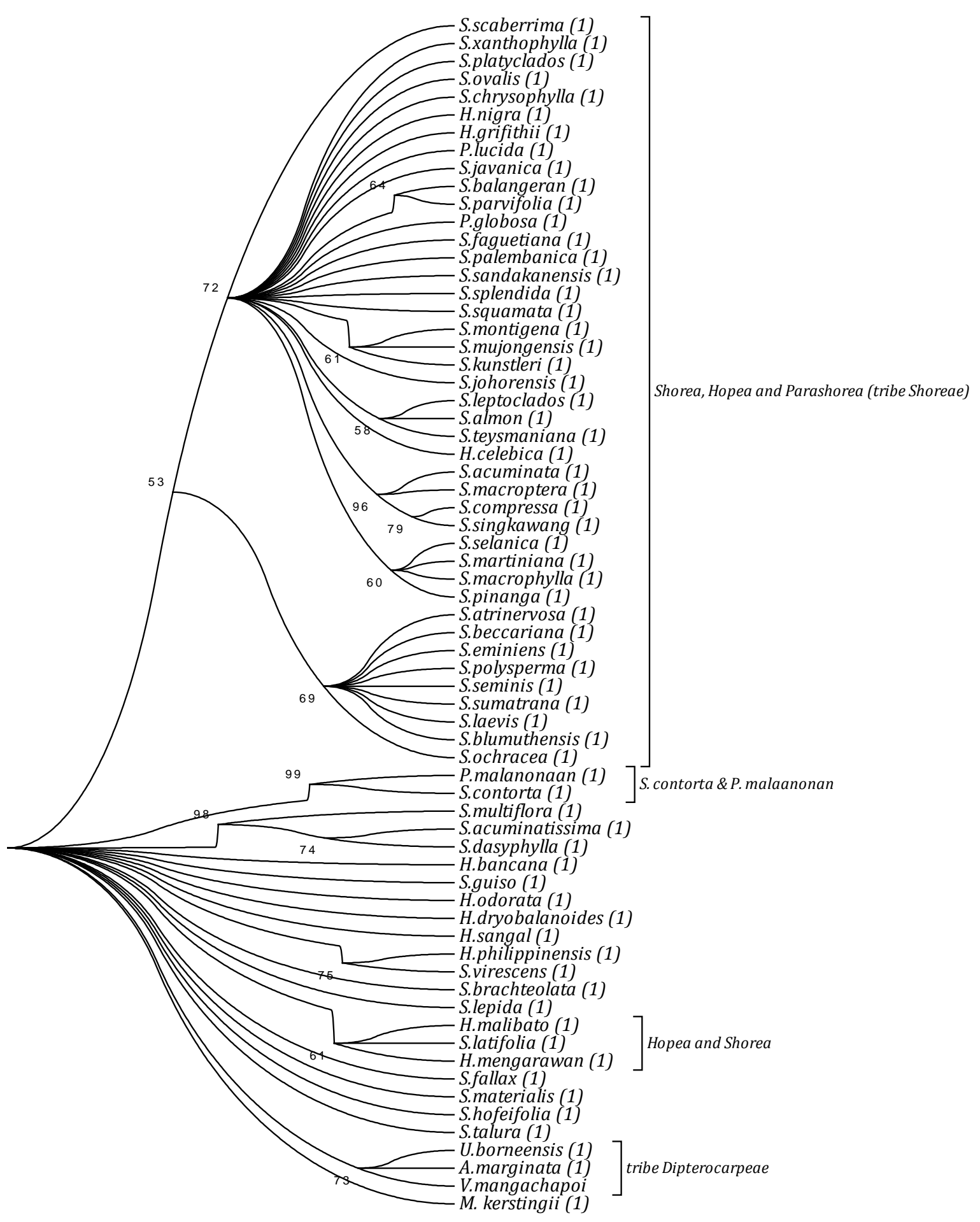


Appendix 10. The identification test of matK (barcode region) using the neighbor joining analysis method with $\mathrm{K} 2 \mathrm{P}$ formula as a parameter for genetic distance. The $(\mathrm{X})$ label behind the species name indicating the sequences from laboratory examined in this study.

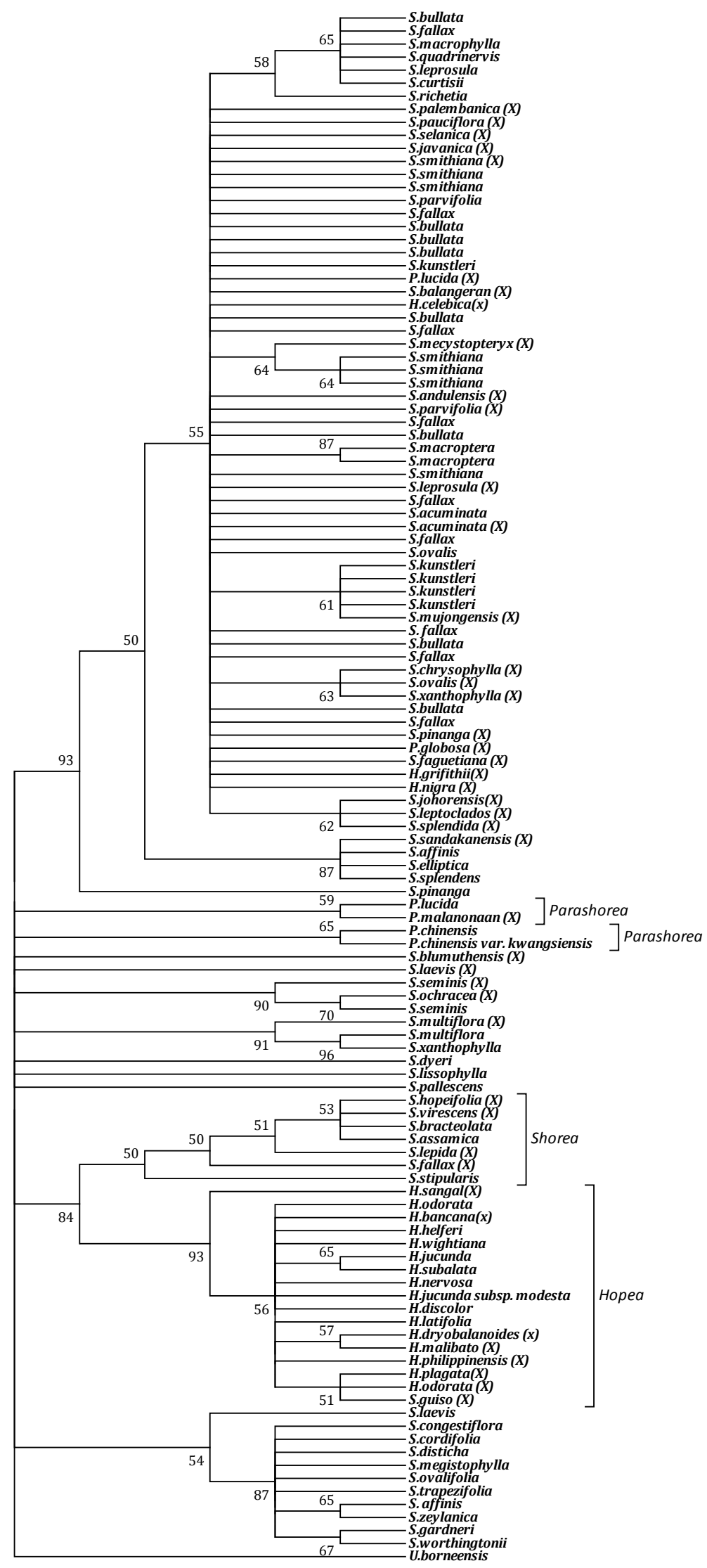


Appendix 11. The identification test of $r b c \mathrm{~L}$ (barcode region) using the neighbor joining analysis method with $\mathrm{K} 2 \mathrm{P}$ formula as a parameter for genetic distance. The number in the bracket indicated the species number tested.

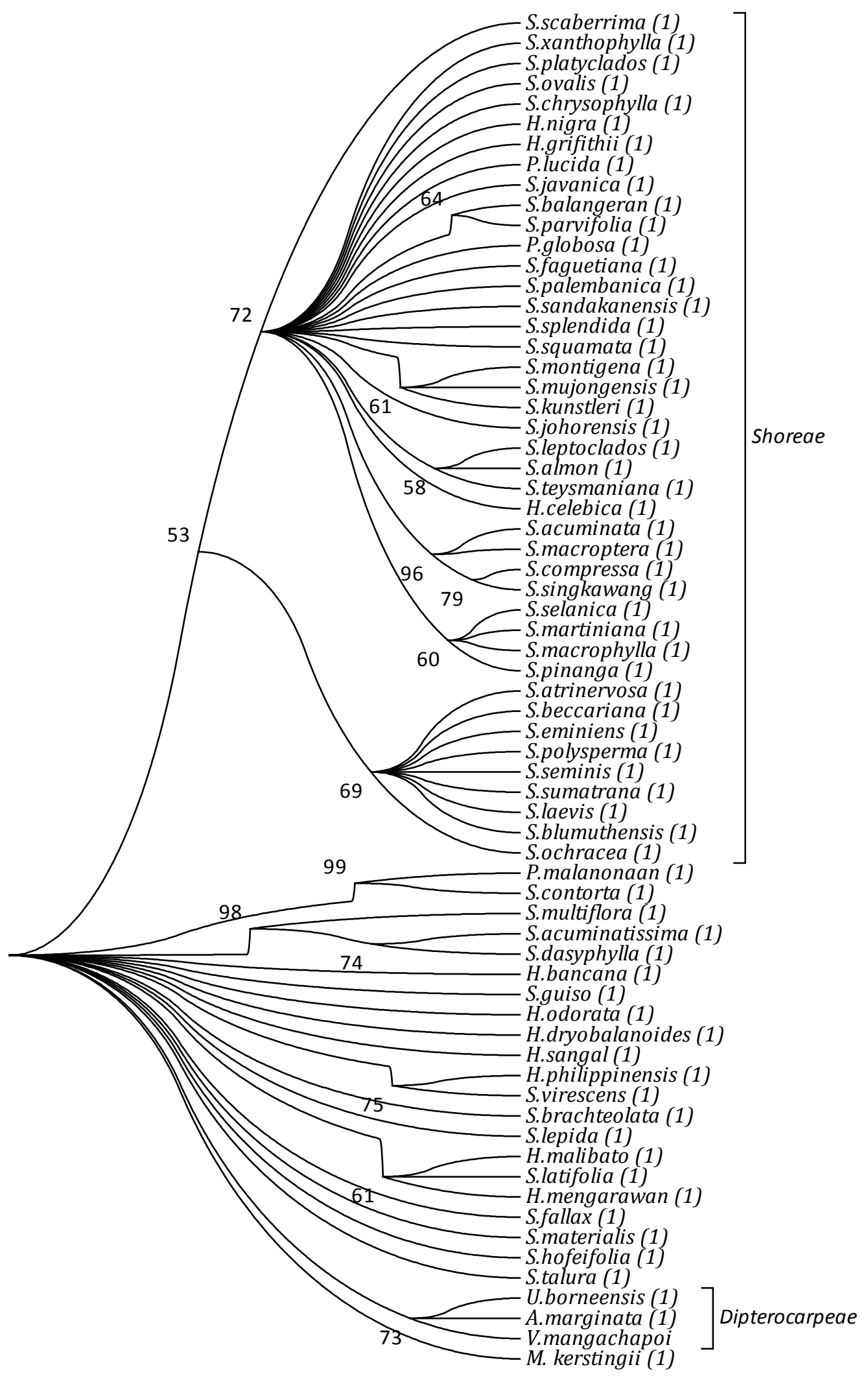


Appendix 12. The cladogram of trn $\mathrm{L}$ intron tree using maximum parsimony analysis and the molecular taxonomic identification key based on the clades of the tree

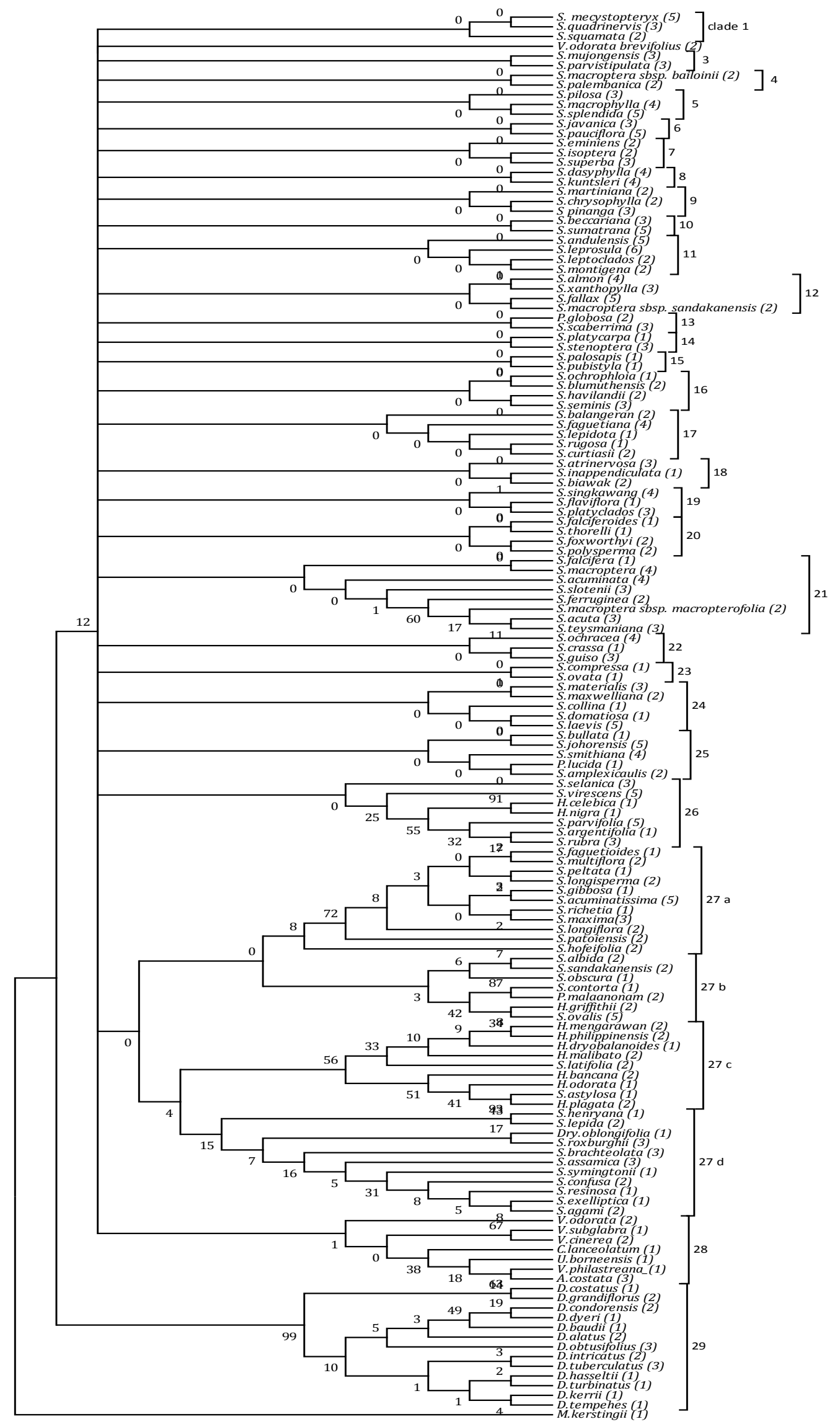


The molecular taxonomic identification key based on clade of the trnL intron phylogenetic tree using maximum parsimony analysis.

\section{Clade 1}

\begin{tabular}{|l|c|c|}
\hline \multirow{2}{*}{\multicolumn{1}{|c|}{ Species }} & \multicolumn{2}{c|}{$\begin{array}{c}\text { Position of } \\
\text { polymorphic sites }\end{array}$} \\
\cline { 2 - 3 } & 52 & 212 \\
\hline S. squamata & - & $\mathrm{G}$ \\
\hline S. mecystopteryx & $\mathrm{A}$ & $\mathrm{G}$ \\
\hline S. quadrinervis & $\mathrm{A}$ & (R) A \\
\hline
\end{tabular}

1. a. Site 52 is (-)

$2 a$

b. If $(A)$

$2 b c$

2. a. Site 212 is $(G)$

S. squamata

b. Site 212 is (G)

S. mecystopteryx

c. If $(A)$

S. quadrinervis

\section{Clade 2}

V. odorata parvistipulata

\section{Clade 3}

There is no differentiation between S. mujongensis and S. parvistipulata

\section{Clade 4}

\begin{tabular}{|l|c|c|c|c|}
\hline \multirow{2}{*}{ Species } & \multicolumn{4}{|c|}{ Position of polymorphic sites } \\
\cline { 2 - 5 } & 244 & 246 & 275 & 276 \\
\hline \multirow{2}{*}{$\begin{array}{l}\text { S. macroptera sbsp. bailonii } \\
\text { S. palembanica }\end{array}$} & - & $\mathrm{G}$ & $\mathrm{A}$ & $\mathrm{C}$ \\
\cline { 2 - 5 } & $\mathrm{A}$ & $\mathrm{R}$ & $\mathrm{M}$ & $\mathrm{Y}$ \\
\hline
\end{tabular}

1. a. Site 244 is (-) $2 a$

b. If $(A)$ $2 b$ 
2. a. Site 246 is (G)

b. If (A)

$3 b$

3. a. Site 275 is $(A)$

$4 a$

b. If (C)

$4 b$

4. a. Site 276 is (C)

S. macroptera sbsp. Bailonii

b. If (Y)

S. palembanica

\section{Clade 5}

\begin{tabular}{|l|c|c|c|c|c|c|c|c|c|}
\hline \multirow{2}{*}{ Species } & \multicolumn{10}{|c|}{ Position of polymorphic sites } \\
\cline { 2 - 12 } & 22 & 51 & 150 & 165 & 172 & 176 & 180 & 266 & 474 \\
\hline S. macrophylla & $\mathrm{A}$ & - & $\mathrm{T}$ & $\mathrm{T}$ & $\mathrm{A}$ & $\mathrm{T}$ & $\mathrm{T}$ & $\mathrm{T}$ & $\mathrm{T}$ \\
\hline S. pilosa & $\mathrm{M}$ & - & $\mathrm{T}$ & $\mathrm{T}$ & $\mathrm{A}$ & $\mathrm{T}$ & $\mathrm{T}$ & $\mathrm{T}$ & $\mathrm{K}$ \\
\hline S. splendida & $\mathrm{A}$ & $\mathrm{A}$ & $\mathrm{W}$ & $\mathrm{K}$ & $\mathrm{R}$ & $\mathrm{W}$ & $\mathrm{Y}$ & $\mathrm{K}$ & $\mathrm{T}$ \\
\hline
\end{tabular}

1. a. Site 22 is $(A)$

b. If (M)

$2 c$

2. a. Site 51 is (-)

$3 a$

b. If (A)

$3 b$

c. If (-)

$3 c$

3. a. Site 150 is $(T)$

$4 a$

b. If (W)

$4 b$

c. If (T)

$4 C$

4. a. Site 165 is (T)

$5 a$

b. If (K)

$5 b$

c. If (T)

$5 c$

5. a. Site 172 is (A)

$6 a$

b. If (R)

$6 b$

c. If (A)

$6 c$

6. a. Site 176 is (T)

$7 a$ 

b. If (W)
$7 b$
c. If (T)
$7 c$

7. a. Site 180 is (T)

$8 a$

b. If $(\mathrm{Y})$

$8 b$

c. If (T)

$8 c$

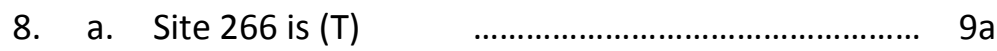

b. If (K)

c. If $(\mathrm{T})$

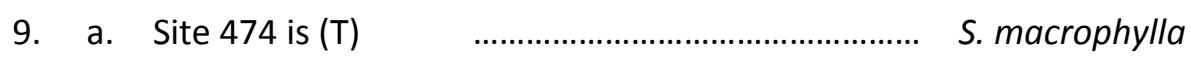

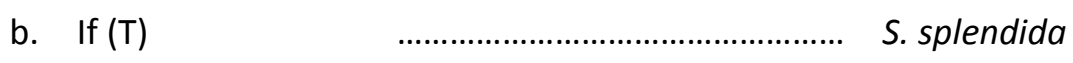

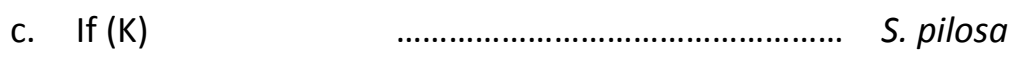

\section{Clade 6}

There is no differentiation between S. javanica and S. pauciflora

\section{Clade 7}

\begin{tabular}{|l|c|c|c|}
\hline \multirow{2}{*}{ Species } & \multicolumn{3}{|c|}{ Position of polymorphic sites } \\
\cline { 2 - 4 } & 184 & 404 & 502 \\
\hline S. eminiens & $\mathrm{T}$ & $\mathrm{A}$ & - \\
\hline S. isoptera & $\mathrm{G}$ & $\mathrm{C}$ & $\mathrm{C}$ \\
\hline S. superba & $\mathrm{T}$ & $\mathrm{C}$ & - \\
\hline
\end{tabular}

1. a. Site 184 is $(T)$

b. If (G)

2c

2. a. Site 404 is (A)

$3 a$

b. If (C)

$3 b$

c. If (C)

$3 c$

3. a. Site 502 is (-)

S. eminiens

b. If $(-)$

S. superba

c. If (C)

S. isoptera 
Clade 8

\begin{tabular}{|l|c|c|c|}
\hline \multirow{2}{*}{ Species } & \multicolumn{3}{|c|}{ Position of polymorphic sites } \\
\cline { 2 - 4 } & 51 & 52 & 195 \\
\hline S. chrysophylla & A & A & C \\
\hline S. pinanga & A & - & G \\
\hline S. martiniana & - & - & G \\
\hline
\end{tabular}

1. a. Site 53 is (-)

$2 a$

b. If $(A)$

$2 b$

2. a. Site 60 is $(A)$

S. dasyphylla

b. If (W)

S. Kuntslerii

Clade 9

\begin{tabular}{|l|c|c|}
\hline \multirow{2}{*}{ Species } & \multicolumn{2}{c|}{$\begin{array}{c}\text { Position of } \\
\text { polymorphic sites }\end{array}$} \\
\cline { 2 - 3 } & 53 & 60 \\
\hline S. dasyphylla & - & $\mathrm{A}$ \\
\hline S. kuntslerii & $\mathrm{A}$ & $\mathrm{W}$ \\
\hline
\end{tabular}

1. a. Site 51 is $(A)$

$2 a b$

b. If $(-)$

$2 c$

2. a. Site 52 is $(A)$

$3 a$

b. If (-)

$3 b$

C. If (-)

$3 c$

3. a. Site 195 is (C)

S. chrysophylla

b. If (G)

S. pinanga

c. If (G)

S. martiniana 
Clade 10

\begin{tabular}{|c|c|c|c|c|c|c|c|}
\hline \multirow{2}{*}{ Species } & \multicolumn{7}{|c|}{ Position of polymorphic sites } \\
\cline { 2 - 9 } & 7 & 81 & 194 & 244 & 276 & 344 & 375 \\
\hline S. beccariana & $\mathrm{A}$ & $\mathrm{A}$ & $\mathrm{A}$ & - & $\mathrm{C}$ & $\mathrm{T}$ & $\mathrm{A}$ \\
\hline S. sumatrana & $\mathrm{R}$ & $\mathrm{M}$ & $\mathrm{R}$ & $\mathrm{A}$ & $\mathrm{Y}$ & $\mathrm{K}$ & $\mathrm{M}$ \\
\hline
\end{tabular}

1. a. Site 7 is $(A)$ $2 a$

b. If $(G)$ $2 b$

2. a. Site 81 is (M) $3 a$

b. If (C) $3 b$

3. a. Site 194 is (R) $4 a b$

b. If (G) $4 b$

4. a. Site 244 is (-) $5 a$

b. If (A) $5 b$

5. a. Site 276 is (C) $6 a$

b. If (Y) $6 b$

6. a. Site 344 is (T) $7 a$

b. If (K) $7 b$

7. a. Site 375 is (A)

S. beccariana

b. If (M)

S. sumatrana 
Clade 11

\begin{tabular}{|l|c|c|}
\hline \multirow{2}{*}{ Species } & \multicolumn{2}{c|}{$\begin{array}{c}\text { Position of } \\
\text { polymorphic sites }\end{array}$} \\
\cline { 2 - 3 } & 51 & 258 \\
\hline S. andulensis & - & - \\
\hline S. leprosula & - & - \\
\hline S. leptoclados & $\mathrm{A}$ & - \\
\hline S. montigena & - & $\mathrm{A}$ \\
& & \\
\hline
\end{tabular}

1. a. Site 51 is (-)

$2 a b$

b. If $(A)$

$2 c$

2. a. Site 258 is (-)

S. andulensis, S. leprosula

b. If $(A)$

S. montigena

c. If (-)

S. leptoclados

Clade 12

\begin{tabular}{|l|c|c|c|c|c|c|}
\hline \multirow{2}{*}{ Species } & \multicolumn{7}{|c|}{ Position of polymorphic sites } \\
\cline { 2 - 7 } & 52 & 178 & 202 & 244 & 276 & 287 \\
\hline S. almon & - & $\mathrm{C}$ & $\mathrm{T}$ & - & $\mathrm{C}$ & $\mathrm{T}$ \\
\hline S. xanthophylla & - & $\mathrm{Y} / \mathrm{A}$ & $\mathrm{K} / \mathrm{G}$ & - & $\mathrm{C}$ & $\mathrm{K} / \mathrm{G}$ \\
\hline S. fallax & $\mathrm{A}$ & $\mathrm{C}$ & $\mathrm{T}$ & $\mathrm{A}$ & $\mathrm{Y} / \mathrm{T}$ & $\mathrm{T}$ \\
\hline S. macroptera & $\mathrm{A}$ & $\mathrm{C}$ & $\mathrm{T}$ & - & $\mathrm{C}$ & $\mathrm{T}$ \\
\hline
\end{tabular}

1. a. Site 52 is (-)

b. If $(A)$

$2 c$

2. a. Site 178 is (C)

$3 a$

b. If $(T)$

$3 b$

c. If (C)

$3 c$

3. a. Site 202 is (K)

$4 a$

b. If $(G)$

$4 b$

c. If (T) 
4. a. Site 244 is (-)

b. If (-)

$5 b$

c. If $(A)$

$5 c$

d. If (-)

$5 d$

5. a. Site 276 is (C)

$6 a b$

b. If $(C)$

$6 b$

c. If $(Y)$

$6 c$

d. If (C)

$6 d$

6. a. Site 287 is ( $T$ )

S. almon, S. xanthophylla

b. If (G)

S. xanthophylla

c. If $(T)$

S. fallax

d. If $(T)$

S. macroptera

\section{Clade 13}

\begin{tabular}{|l|c|c|c|c|}
\hline \multirow{2}{*}{ Species } & \multicolumn{4}{|c|}{ Position of polymorphic sites } \\
\cline { 2 - 5 } & 51 & 52 & 53 & 212 \\
\hline P. globosa & - & - & - & G \\
\hline S. scaberrima & A & A & A & R \\
\hline
\end{tabular}

1. a. Site 51 is (-)

b. If $(A)$

$2 b$

2. a. Site 52 is (-)

$3 a$

b. If $(A)$

$3 b$

3. a. Site 53 is (-)

$4 a$

b. If (A)

$4 b$

4. a. Site 212 is (G)

P. globosa

b. If $(R)$

S. scaberrima 


\section{Clade 14}

There is no differentiation between S. platycarpa and S. stenoptera

\section{Clade 15}

There is no differentiation between S. palosapis and S. pubistyla

Clade 16

\begin{tabular}{|l|c|c|c|}
\hline \multirow{2}{*}{ Species } & \multicolumn{3}{|c|}{ Position of polymorphic sites } \\
\cline { 2 - 4 } & 90 & 151 & 283 \\
\hline S. blumuthensis & $\mathrm{G}$ & $\mathrm{G}$ & $\mathrm{T}$ \\
\hline S. havilandii & $\mathrm{G}$ & $\mathrm{G}$ & $\mathrm{T}$ \\
\hline S. ochroploia & $\mathrm{A}$ & $\mathrm{T}$ & $\mathrm{T}$ \\
\hline S. seminis & $\mathrm{G}$ & $\mathrm{G}$ & $\mathrm{K}$ \\
\hline
\end{tabular}

1. a. Site 90 is $(G)$

b. If (A)

$2 b$

2. a. Site 151 is (G)

$3 a b$

b. If (T)

$3 c$

3. a. Site 283 is (T)

S. blumuthensis, S. havilandii,

S. seminis

b. If (G)

S. seminis

c. If $(T)$

S. ochroploia 
Clade 17

\begin{tabular}{|l|c|c|c|c|c|c|c|c|c|}
\hline \multirow{2}{*}{ Species } & \multicolumn{10}{|c|}{ Position of polymorphic sites } \\
\cline { 2 - 11 } & 7 & 15 & 19 & 22 & 178 & 202 & 287 & 333 & 360 \\
\hline S. balangeran & $\mathrm{A}$ & $\mathrm{A}$ & $\mathrm{T}$ & $\mathrm{A}$ & $\mathrm{C}$ & $\mathrm{T}$ & $\mathrm{T}$ & $\mathrm{C}$ & $\mathrm{A}$ \\
\hline S. faguetiana & $\mathrm{W}$ & $\mathrm{R}$ & $\mathrm{Y}$ & $\mathrm{M}$ & $\mathrm{Y}$ & $\mathrm{K}$ & $\mathrm{K}$ & $\mathrm{M}$ & $\mathrm{M}$ \\
\hline S. lepidota & $\mathrm{A}$ & $\mathrm{A}$ & $\mathrm{T}$ & $\mathrm{A}$ & $\mathrm{C}$ & $\mathrm{T}$ & $\mathrm{T}$ & $\mathrm{C}$ & $\mathrm{A}$ \\
\hline S. rugosa & $\mathrm{A}$ & $\mathrm{A}$ & $\mathrm{T}$ & $\mathrm{A}$ & $\mathrm{C}$ & $\mathrm{T}$ & $\mathrm{T}$ & $\mathrm{C}$ & $\mathrm{A}$ \\
\hline S. curtisii & $\mathrm{A}$ & $\mathrm{A}$ & $\mathrm{T}$ & $\mathrm{A}$ & $\mathrm{C}$ & $\mathrm{T}$ & $\mathrm{T}$ & $\mathrm{C}$ & $\mathrm{A}$ \\
\hline
\end{tabular}

1. a. Site 7 is $(A)$

b. If (T)

$2 b$

2. a. Site 15 is $(A)$

$3 a$

b. If $(R)$

$3 b$

3. a. Site 19 is $(T)$

$4 a$

b. If $(Y)$

$4 b$

4. a. Site 22 is (A)

$5 a$

b. If (M)

$5 b$

5. a. Site 178 is (C)

$6 a$

b. If $(\mathrm{Y})$

$6 b$

6. a. Site 202 is (T)

$7 a$

b. If (K)

$7 b$

7. a. Site 287 is (T)

$8 a$

b. If (K)

$8 b$

8. a. Site 333 is (C)

$9 a$

b. If (M)

$9 a b$

9. a. Site 360 is (A)

S. balangeran, S. lepidota, S. rugosa,

S. Curtisii, S. faguetiana

b. If (C)

S. faguetiana 
Clade 18

\begin{tabular}{|l|c|}
\hline \multicolumn{1}{|c|}{ Species } & $\begin{array}{c}\text { Position of } \\
\text { polymorphic } \\
\text { sites }\end{array}$ \\
\cline { 2 - 2 } & 51 \\
\hline S. atrinervosa & - \\
\hline S. biawak & $\mathrm{A}$ \\
\hline S. inapendiculata & - \\
\hline
\end{tabular}

1. a. Site 51 is (-)

S. atrinervosa, S. inapendiculata

b. If (A)

S. biawak

Clade 19

\begin{tabular}{|l|c|c|}
\hline \multirow{2}{*}{ Species } & \multicolumn{2}{c|}{$\begin{array}{c}\text { Position of } \\
\text { polymorphic sites }\end{array}$} \\
\cline { 2 - 3 } & 173 & 275 \\
\hline S. flaviflora & $\mathrm{G}$ & $\mathrm{A}$ \\
\hline S. platyclados & $\mathrm{G}$ & $\mathrm{A}$ \\
\hline S. singkawang & $\mathrm{R}$ & $\mathrm{M}$ \\
\hline
\end{tabular}

1. a. Site 173 is $(G)$

$2 a$

b. If (A)

$2 a b$

2. a. Site 275 is $(A)$

S. flaviflora, S. Platyclados, S. singkawang

b. If (C)

S. singkawang 
Clade 20

\begin{tabular}{|l|c|c|c|c|c|c|c|c|c|}
\hline \multirow{2}{*}{ Species } & \multicolumn{10}{|c|}{ Position of polymorphic sites } \\
\cline { 2 - 12 } & 11 & 16 & 62 & 66 & 67 & $364-372$ & 380 & 475 & 502 \\
\hline S. falciferoides & T & A & C & A & G & - & & - & - \\
\hline S. foxworthyii & Y & M & Y & W & K & - & & C & C \\
\hline S. polysperma & T & A & C & A & G & - & & - & - \\
\hline S. thorelii & T & A & C & A & G & TTTCAAATA & A & - & - \\
\hline
\end{tabular}

1. a. Site 11 is $(\mathrm{T})$

b. If (C) $2 b$

2. a. Site 16 is (A) $3 a$

b. If (M) $3 b$

3. a. Site 62 is (C) $4 a$

b. If (Y) $4 b$

4. a. Site 66 is (A) $5 a$

b. If (W) $5 b$

5. a. Site 67 is $(G)$ $6 a b$

b. If $(K)$ $6 c$

6. a. Site $364-372$ is (-) $8 a$

b. If (TTTCAAATA) 7

c. If (-) $8 b$

7. Site 380 is (A) $8 c$

8. a. Site 475 is (-) $9 a$

b. If (C) $9 b$

c. If (-) $9 c$

9. a. Site 502 is (-)

S. falciferoides, S. polysperma

b. If (C)

S. foxworthyii

c. If (-)

S. thorelii 
Clade 21

\begin{tabular}{|l|c|c|c|c|}
\hline \multirow{2}{*}{ Species } & \multicolumn{5}{c|}{ Position of polymorphic sites } \\
\cline { 2 - 5 } & 52 & 275 & 294 & 500 \\
\hline S. falcifera & $\mathrm{A}$ & $\mathrm{A}$ & $\mathrm{T}$ & $\mathrm{C}$ \\
\hline S. macroptera & $\mathrm{A}$ & $\mathrm{A}$ & $\mathrm{T}$ & $\mathrm{C}$ \\
\hline S. acuminata & - & $\mathrm{A}$ & $\mathrm{T}$ & $\mathrm{C}$ \\
\hline S. slotenii & - & $\mathrm{M}$ & $\mathrm{K}$ & $\mathrm{C}$ \\
\hline S. ferruginea & - & $\mathrm{A}$ & $\mathrm{G}$ & $\mathrm{C}$ \\
\hline S. macroptera sbsp. macropterifolia & $\mathrm{A}$ & $\mathrm{A}$ & $\mathrm{G}$ & $\mathrm{Y}$ \\
\hline S. acuta & $\mathrm{A}$ & $\mathrm{A}$ & $\mathrm{G}$ & $\mathrm{C}$ \\
\hline S. teysmaniana & - & $\mathrm{A}$ & $\mathrm{G}$ & $\mathrm{C}$ \\
\hline
\end{tabular}

1. a. Site 52 is (A) $2 a$

b. If (-)

$2 b c$

2. a. Site 275 is (A)

$3 a b$

b. If $(A)$

$3 c d$

c. If (C)

$3 e$

3. a. Site 294 is (T)

$4 a$

b. If (G)

$4 b c$

c. If (T)

$4 d$

d. If (G)

$4 e$

e. If $(K)$

$4 f$

4. a. Site 500 is (C)

S. falcifera, S. macroptera

b. If (T)

S. macroptera sbsp. macropterifolia

c. If (C)

S. acuta, S. macroptera sbsp. macropterifolia

d. If (C)

S. acuminate, S. slotenii

e. If (C)

S. teysmaniana, S. ferruginea, S. slotenii

f. If (C)

S. slotenii 
Clade 22

\begin{tabular}{|c|c|c|c|c|c|c|c|c|c|c|c|c|c|}
\hline \multirow{2}{*}{ Species } & \multicolumn{13}{|c|}{ Position of polymorphic sites } \\
\hline & 7 & 90 & 151 & 194 & 244 & 246 & 275 & 276 & $336-341$ & 344 & 363 & 375 & 378 \\
\hline S. crassa & $A$ & G & G & $A$ & - & G & $A$ & $\mathrm{C}$ & - & $\mathrm{T}$ & $A$ & $A$ & $A$ \\
\hline S. guiso & $\mathrm{R}$ & $\mathrm{R}$ & $K$ & $R$ & $A$ & $\mathrm{G}$ & $M$ & $Y$ & AAGAAT & $K$ & W & $M$ & $\mathrm{R}$ \\
\hline S. ochracea & $A$ & $\mathrm{G}$ & $\mathrm{G}$ & $A$ & $A$ & $R$ & $M$ & $Y$ & AAGAAT & $T$ & W & $A$ & $A$ \\
\hline
\end{tabular}

1. a. Site 7 is $(A)$ $2 a$

b. If (R) $2 b$

2. a. Site 90 is (G) $3 a$

b. If $(R)$ $3 b$

3. a. Site 151 is (G) $4 a$

b. If (K) $4 b$

4. a. Site 194 is (A) $5 a b$

b. If (R) $5 c$

5. a. Site 244 is (-) $6 a$

b. If $(A)$ $6 b$

c. If $(A)$ $6 c$

6. a. Site 246 is (G) $7 a$

b. If (R) $7 b$

c. If $(G)$ 7c

7. a. Site 275 is (A) $8 a$

b. If (M) $8 b$

c. If (M) $8 c$

8. a. Site 276 is (C) $9 a$

b. If $(Y)$ $9 b$

c. If $(Y)$ $9 c$

9. a. Site $336-341$ is (-) $10 a$ 

b. If (AAGAAT)
$10 b$
c. If (AAGAAT)
$10 c$

10. a. Site 344 is $(T)$

$11 a$

b. If (T)

$11 b$

c. If (K)

$11 c$

11. a. Site 363 is (A)

$12 a$

b. If (W)

$12 b$

c. If (W)

$12 c$

12. a. Site 375 is $(A)$

$13 a$

b. If $(A)$

$13 b$

c. If (M)

$13 c$

13. a. Site 378 is $(A)$

S. crassa

b. If $(A)$

S. ochracea

c. If (R)

S. guiso

\section{Clade 23}

\begin{tabular}{|l|c|}
\hline \multirow{2}{*}{ Species } & Position of polymorphic sites \\
\cline { 2 - 2 } & 51 \\
\hline S. compressa & - \\
\hline S. ovata & $\mathrm{A}$ \\
\hline
\end{tabular}

1. a. Site 51 is (-)

S. compressa

b. If $(A)$

S. ovata 


\section{Clade 24}

\begin{tabular}{|l|c|c|c|c|c|}
\hline \multirow{2}{*}{ Species } & \multicolumn{5}{|c|}{ Position of polymorphic sites } \\
\cline { 2 - 6 } & 51 & 90 & 151 & 265 & 332 \\
\hline S. colina & - & $\mathrm{G}$ & $\mathrm{G}$ & $\mathrm{C}$ & $\mathrm{T}$ \\
\hline S. domatiosa & - & $\mathrm{G}$ & $\mathrm{G}$ & $\mathrm{C}$ & $\mathrm{T}$ \\
\hline S. laevis & $\mathrm{A}$ & $\mathrm{G}$ & $\mathrm{G}$ & $\mathrm{Y}$ & $\mathrm{Y}$ \\
\hline S. materialis & - & $\mathrm{R}$ & $\mathrm{K}$ & $\mathrm{Y}$ & $\mathrm{T}$ \\
\hline S. maxwelliana & $\mathrm{A}$ & $\mathrm{G}$ & $\mathrm{G}$ & $\mathrm{C}$ & $\mathrm{T}$ \\
\hline
\end{tabular}

1. a. Site 51 is (-)

$2 a b$

b. If $(A)$

$2 c$

2. a. Site 90 is $(\mathrm{G})$ $3 a$

b. If (R)

$3 b$

c. If (G)

$3 c$

3. a. Site 151 is (G)

$4 a$

b. If $(K)$

$4 b$

c. If (G)

$4 c d$

4. a. Site 265 is (C)

$5 a$

b. If $(Y)$

$5 b$

c. If (Y)

$5 c$

d. If (C)

$5 d$

5. a. Site 332 is (T)

S. colina, S. domatiosa

b. If (T)

S. materialis

c. If $(Y)$

S. laevis

d. If $(T)$

S. maxwelliana 


\section{Clade 25}

\begin{tabular}{|l|c|c|c|}
\hline \multirow{2}{*}{\multicolumn{1}{|c|}{ Species }} & \multicolumn{3}{c|}{ Position of polymorphic sites } \\
\cline { 2 - 4 } & 51 & 52 & 53 \\
\hline P. lucida & - & - & - \\
\hline S. amplexicaulis & - & - & - \\
\hline S. bullata & $\mathrm{A}$ & $\mathrm{A}$ & $\mathrm{A}$ \\
\hline S. johorensis & $\mathrm{A}$ & - & - \\
\hline S. smithiana & $\mathrm{A}$ & - & - \\
\hline
\end{tabular}

1. a. Site 51 is (-)

$2 a$

b. If (A)

$2 b c$

2. a. Site 52 is (-)

$3 a$

b. If $(A)$

$3 b$

c. If (-)

$3 c$

3. a. Site 53 is (-)

b. If (A)

c. If (-)
P. lucida, S. amplexicaulis

S. bullata

S. johorensis, S. smithiana

\section{Clade 26}

\begin{tabular}{|c|c|c|c|c|c|c|c|c|c|c|c|c|c|c|c|}
\hline \multirow{2}{*}{ Species } & \multicolumn{15}{|c|}{ Position of polymorphic sites } \\
\hline & 5 & 10 & 17 & 21 & 22 & 58 & 115 & 156 & 177 & 181 & 193 & 212 & 231 & 244 & 246 \\
\hline H. celebica & A & A & C & $\mathrm{T}$ & C & C & A & G & A & C & C & A & $\mathrm{T}$ & - & G \\
\hline H. nigra & C & $\mathrm{G}$ & $\mathrm{A}$ & $\mathrm{T}$ & $\mathrm{C}$ & $\mathrm{C}$ & A & G & A & C & C & A & $\mathrm{T}$ & - & G \\
\hline S. argentifolia & $\mathrm{C}$ & $\mathrm{G}$ & $\mathrm{C}$ & $\mathrm{C}$ & A & $\mathrm{C}$ & A & G & A & $\mathrm{C}$ & $\mathrm{C}$ & A & $\mathrm{T}$ & - & $\mathrm{G}$ \\
\hline S. parvifolia & $\mathrm{C}$ & $\mathrm{G}$ & $\mathrm{C}$ & $\mathrm{C}$ & $A$ & $\mathrm{Y}$ & A & G & $\mathrm{M}$ & $Y$ & $\mathrm{C}$ & A & $\mathrm{T}$ & - & $\mathrm{G}$ \\
\hline S. rubra & $\mathrm{C}$ & $\mathrm{G}$ & $\mathrm{C}$ & $\mathrm{C}$ & $A$ & C & A & G & A & $C$ & $C$ & A & $T$ & - & $\mathrm{G}$ \\
\hline S. selanica & $C$ & $\mathrm{G}$ & $\mathrm{C}$ & $\mathrm{C}$ & $A$ & $\mathrm{C}$ & $\mathrm{R}$ & $\mathrm{S}$ & A & $C$ & $Y$ & G & $T$ & A & G \\
\hline S. virescens & C & G & C & C & A & C & A & $S$ & A & C & C & G & K & A & $\mathrm{R}$ \\
\hline
\end{tabular}




\begin{tabular}{|c|c|c|c|c|c|c|c|c|c|c|}
\hline \multirow{2}{*}{ Species } & \multicolumn{10}{|c|}{ Position of polymorphic sites } \\
\hline & 275 & 276 & 298 & 333 & 344 & 375 & 493 & 534 & 537 & 333 \\
\hline H. celebica & A & $\mathrm{C}$ & A & C & $T$ & $\mathrm{~A}$ & A & - & $\mathrm{C}$ & $\mathrm{C}$ \\
\hline H. nigra & A & C & A & C & $T$ & A & A & C & C & $\mathrm{C}$ \\
\hline S. argentifolia & A & $\mathrm{C}$ & A & $\mathrm{C}$ & $T$ & $\mathrm{~A}$ & A & $\mathrm{N}$ & $\mathrm{C}$ & $\mathrm{C}$ \\
\hline S. parvifolia & A & C & A & $\mathrm{C}$ & $T$ & A & W & $\mathrm{T}$ & C & C \\
\hline S. rubra & A & C & A & $C$ & $T$ & $A$ & A & $\mathrm{N}$ & C & $\mathrm{C}$ \\
\hline S. selanica & A & $C$ & $\mathrm{R}$ & $Y$ & $\mathrm{~K}$ & $M$ & A & $\mathrm{T}$ & G & $Y$ \\
\hline S. virescens & $\mathrm{M}$ & Y & A & C & $\mathrm{T}$ & A & A & $\mathrm{T}$ & C & C \\
\hline
\end{tabular}

1. a. Site 5 is $(A)$ $2 a$

b. If (C) $2 b$

2. a. Site 10 is $(A)$ H. celebica

b. If $(G)$ 3

3. a. Site 17 is (A) $4 a$

b. If (C) $4 b$

4. a. Site 21 is $(T)$ $5 a$

b. If (C) $5 b$

5. a. Site 22 is (C) H. nigra

b. If $(A)$ 6

6. a. Site 58 is (C) 7

b. If $(Y)$

S. parvifolia

7. a. Site 115 is (A)

8

b. If (R)

S. selanica

8. a. Site 156 is (G)

S. argenti folia

b. If (S)

S. virescens 
Clade 27a

\begin{tabular}{|c|c|c|c|c|c|c|c|c|c|c|c|c|c|}
\hline \multirow{2}{*}{ Species } & \multicolumn{13}{|c|}{ Position of polymorphic sites } \\
\hline & 51 & 178 & 202 & 244 & 246 & 275 & 276 & 282 & 287 & 326 & 344 & 487 & 507 \\
\hline S. acuminatissima & - & $\mathrm{T}$ & G & - & G & A & $\mathrm{C}$ & $\mathrm{T}$ & G & G & $\mathrm{T}$ & A & A \\
\hline S. faguetioides & - & $\mathrm{T}$ & G & - & $\mathrm{G}$ & A & $\mathrm{C}$ & $\mathrm{T}$ & G & G & $\mathrm{T}$ & A & A \\
\hline S. gibbosa & - & $\mathrm{T}$ & G & - & $\mathrm{G}$ & A & $\mathrm{C}$ & $\mathrm{T}$ & G & G & $\mathrm{T}$ & A & A \\
\hline S. hopeifolia & $\mathrm{A}$ & $\mathrm{Y}$ & $\mathrm{K}$ & A & $\mathrm{R}$ & A & $\mathrm{C}$ & $\mathrm{G}$ & $\mathrm{K}$ & $\mathrm{G}$ & $\mathrm{T}$ & $\mathrm{A}$ & $\mathrm{A}$ \\
\hline S. longisperma & - & $\mathrm{T}$ & $\mathrm{G}$ & - & $\mathrm{G}$ & $\mathrm{M}$ & $\mathrm{Y}$ & $\mathrm{T}$ & G & $\mathrm{G}$ & $\mathrm{T}$ & $\mathrm{M}$ & A \\
\hline S. longiflora & - & $\mathrm{T}$ & G & - & G & A & $\mathrm{C}$ & $\mathrm{T}$ & G & G & $\mathrm{T}$ & A & A \\
\hline S. maxima & - & $\mathrm{T}$ & G & - & G & $\mathrm{A}$ & $\mathrm{C}$ & $\mathrm{T}$ & G & G & K & $\mathrm{A}$ & A \\
\hline S. multiflora & - & $\mathrm{T}$ & G & - & $\mathrm{G}$ & A & $\mathrm{C}$ & $\mathrm{T}$ & G & G & $\mathrm{T}$ & A & $\mathrm{M}$ \\
\hline S. patoiensis & - & $\mathrm{T}$ & G & - & $\mathrm{G}$ & A & $\mathrm{C}$ & $\mathrm{T}$ & G & G & $\mathrm{T}$ & A & $\mathrm{A}$ \\
\hline S. peltata & - & $\mathrm{T}$ & G & - & G & $\mathrm{A}$ & $\mathrm{C}$ & $\mathrm{T}$ & G & $\mathrm{T}$ & $\mathrm{T}$ & $\mathrm{A}$ & $\mathrm{A}$ \\
\hline S. rihetia & - & $\mathrm{T}$ & G & - & $\mathrm{G}$ & A & $\mathrm{C}$ & $\mathrm{T}$ & G & G & $\mathrm{T}$ & $\mathrm{A}$ & A \\
\hline
\end{tabular}

1. a. Site 51 is (-)

$2 a$

b. If (A)

$2 b$

2. a. Site 178 is $(T)$

$3 a$

b. If $(Y)$

$3 b$

3. a. Site 202 is (G)

$4 a$

b. If (K)

$4 b$

4. a. Site 214 is (-)

5

b. If (A)

\section{S. hopeifolia}

5. a. Site 275 is (A)

$6 a$

b. If (M)

$6 b$

6. a. Site 276 is (C)

$7 a$

8. a. Site 344 is (T)

$9 a$

b. If (K)

S. maxima

9. a. Site 487 is (M)

S. longisperma

b. If (A)

10

9. a. Site 507 is (M)

S. multiflora

b. If (A)

S. patoiensis, S. richetia, S. longiflora, S. gibbosa, $S$.

faguetioides, S. acuminatissima, 
Clade 27b

\begin{tabular}{|c|c|c|c|c|c|c|c|c|c|c|c|c|c|c|c|c|c|c|c|c|}
\hline \multirow[b]{2}{*}{ Species } & \multicolumn{20}{|c|}{ Position of polymorphic sites } \\
\hline & 5 & 22 & 38 & 42 & 53 & 195 & 217 & 218 & 257 & 294 & 318 & 322 & 358 & 522 & 523 & 525 & 529 & 534 & 535 & 537 \\
\hline H. grifithii & $\mathrm{C}$ & $\mathrm{A}$ & - & A & $\mathrm{A}$ & $\mathrm{G}$ & $\mathrm{C}$ & $\mathrm{G}$ & $\mathrm{C}$ & $\mathrm{T}$ & A & A & $\mathrm{C}$ & $\mathrm{G}$ & $\mathrm{W}$ & $\mathrm{A}$ & $\mathrm{G}$ & $\mathrm{T}$ & $\mathrm{C}$ & $\mathrm{T}$ \\
\hline P. malaanonan & $\mathrm{M}$ & $\mathrm{M}$ & - & $\mathrm{A}$ & $\mathrm{G}$ & $\mathrm{G}$ & $\mathrm{C}$ & $\mathrm{G}$ & $\mathrm{C}$ & $\mathrm{T}$ & G & $\mathrm{T}$ & $\mathrm{Y}$ & $\mathrm{G}$ & $\mathrm{W}$ & $\mathrm{A}$ & G & $\mathrm{T}$ & $\mathrm{Y}$ & $\mathrm{Y}$ \\
\hline S. albida & $\mathrm{C}$ & $\mathrm{A}$ & - & $\mathrm{A}$ & $\mathrm{A}$ & $\mathrm{G}$ & $\mathrm{C}$ & G & $\mathrm{C}$ & $\mathrm{T}$ & A & A & $\mathrm{C}$ & $\mathrm{G}$ & $\mathrm{W}$ & $\mathrm{A}$ & G & $\mathrm{T}$ & $\mathrm{C}$ & $\mathrm{G}$ \\
\hline S. contorta & A & A & - & A & A & $\mathrm{G}$ & $\mathrm{C}$ & G & $\mathrm{C}$ & $\mathrm{T}$ & G & $\mathrm{T}$ & $\mathrm{C}$ & $\mathrm{G}$ & G & A & G & $\mathrm{C}$ & $\mathrm{C}$ & $\mathrm{T}$ \\
\hline S. obscur & $\mathrm{C}$ & A & - & A & A & $\mathrm{G}$ & $\mathrm{C}$ & $\mathrm{G}$ & $\mathrm{C}$ & $\mathrm{T}$ & A & A & $\mathrm{C}$ & G & $\mathrm{W}$ & $\mathrm{A}$ & G & $\mathrm{N}$ & $\mathrm{C}$ & $\mathrm{N}$ \\
\hline S. ovalis & $\mathrm{C}$ & A & $\mathrm{C}$ & $\mathrm{R}$ & A & $\mathrm{S}$ & $\mathrm{Y}$ & $\mathrm{R}$ & $\mathrm{Y}$ & $\mathrm{K}$ & A & A & $\mathrm{C}$ & $\mathrm{R}$ & $\mathrm{K}$ & $\mathrm{R}$ & $\mathrm{R}$ & $\mathrm{C}$ & $\mathrm{C}$ & $\mathrm{T}$ \\
\hline S. sandakanensis & $\mathrm{C}$ & $\mathrm{A}$ & - & $\mathrm{A}$ & $\mathrm{A}$ & $\mathrm{G}$ & $\mathrm{C}$ & G & $\mathrm{C}$ & $\mathrm{T}$ & A & A & $\mathrm{C}$ & $\mathrm{G}$ & $\mathrm{W}$ & $\mathrm{A}$ & G & $\mathrm{C}$ & $\mathrm{C}$ & G \\
\hline
\end{tabular}

1. a. Site 5 is (C) $3 b$

b. If (M)

$2 a$

c. If $(A)$

2. a. Site 5 is $(A)$

$3 a$

b. If (M)

\section{P. malaanonan}

3. a. Site 22 is (A)

$4 a$

b. If (-)

$4 b$

4. a. Site 214 is (-)

$5 a$

b. If $(A)$

$5 b$

5. a. Site 246 is (G)

$6 a$

b. If (R)

$6 b$

6. a. Site 275 is (A)

$7 a$

b. If (M)

$7 b$

7. a. Site 276 is (A)

$8 a c$

b. If (M)

$8 b$

8. a. Site 282 is (T)

$9 a$

b. If $(T)$

$9 a$

c. If (G)

$9 c$

9. a. Site 287 is (G)

$10 a$

b. If $(K)$ 
10. a. Site 326 is (G)

b. If $(T)$

S. multiflora

11. a. Site 344 is (K)

S. patoiensis

b. If $(T)$

S. richetia, S. gibbosa

12. a. Site 487 is $(A)$

$13 a$

b. If $(M)$

S. longisperma

13. a. Site 507 is (A

S. acuminatissima

Clade 27c

\begin{tabular}{|l|c|c|c|c|c|c|c|c|c|c|}
\hline \multirow{2}{*}{ Species } & \multicolumn{10}{|c|}{ Position of polymorphic sites } \\
\cline { 2 - 14 } & 7 & 14 & 52 & 194 & 275 & 293 & 322 & 333 & 378 & 397 \\
\hline H. bancana & $\mathrm{A}$ & $\mathrm{T}$ & - & $\mathrm{G}$ & $\mathrm{C}$ & $\mathrm{A}$ & $\mathrm{A}$ & $\mathrm{C}$ & $\mathrm{A}$ & $\mathrm{C}$ \\
\hline H.dryobalanoides & $\mathrm{A}$ & $\mathrm{T}$ & $\mathrm{A}$ & $\mathrm{A}$ & $\mathrm{A}$ & $\mathrm{A}$ & $\mathrm{A}$ & $\mathrm{C}$ & $\mathrm{A}$ & $\mathrm{C}$ \\
\hline H. malibato & $\mathrm{A}$ & $\mathrm{T}$ & - & $\mathrm{A}$ & $\mathrm{A}$ & $\mathrm{A}$ & $\mathrm{A}$ & $\mathrm{C}$ & $\mathrm{A}$ & $\mathrm{C}$ \\
\hline H. mengarawan & $\mathrm{A}$ & $\mathrm{T}$ & - & $\mathrm{A}$ & $\mathrm{A}$ & $\mathrm{A}$ & $\mathrm{A}$ & $\mathrm{C}$ & $\mathrm{A}$ & $\mathrm{C}$ \\
\hline H. odorata & $\mathrm{G}$ & $\mathrm{T}$ & - & $\mathrm{G}$ & $\mathrm{C}$ & $\mathrm{A}$ & $\mathrm{A}$ & $\mathrm{C}$ & $\mathrm{G}$ & $\mathrm{C}$ \\
\hline H. philippinensis & $\mathrm{A}$ & $\mathrm{T}$ & - & $\mathrm{A}$ & $\mathrm{A}$ & $\mathrm{A}$ & $\mathrm{A}$ & $\mathrm{C}$ & $\mathrm{A}$ & $\mathrm{C}$ \\
\hline H. plagata & $\mathrm{G}$ & $\mathrm{A}$ & - & $\mathrm{G}$ & $\mathrm{A}$ & $\mathrm{A}$ & $\mathrm{A}$ & $\mathrm{C}$ & $\mathrm{A}$ & $\mathrm{C}$ \\
\hline S. astylosa & $\mathrm{G}$ & $\mathrm{T}$ & - & $\mathrm{G}$ & $\mathrm{A}$ & $\mathrm{C}$ & $\mathrm{C}$ & $\mathrm{A}$ & $\mathrm{A}$ & $\mathrm{A}$ \\
\hline S. latifolia & $\mathrm{A}$ & $\mathrm{T}$ & - & $\mathrm{A}$ & $\mathrm{A}$ & $\mathrm{A}$ & $\mathrm{A}$ & $\mathrm{C}$ & $\mathrm{A}$ & $\mathrm{C}$ \\
\hline
\end{tabular}

1. a. Site 7 is $(A)$ $2 a$

b. If $(G)$ $2 b$

2. a. Site 14 is $(T)$ $3 a$

b. If $(A)$ $8 b$

3. a. Site 52 is (-) $4 a$

b. If $(A)$

H. dryobalanoides

4. a. Site 194 is (A)

$5 a$

b. If $(G)$

$5 b$

5. a. Site 275 is (A)

$6 a c$

b. If (C)

$6 b$

6. a. Site 293 is (A)

$7 a$ 
b. If (C)

7. a. Site 378 is (A)

b. If $(G)$

8. a. Site 379 is (C)

\section{S. astylosa}

$8 a$

H. odorata

S. Iatifolia, H. malibato, $H$.

mengarawan, $H$. philippinensis

\section{Clade 27d}

\begin{tabular}{|c|c|c|c|c|c|c|c|c|c|c|c|c|c|c|c|}
\hline \multirow{2}{*}{ Species } & \multicolumn{15}{|c|}{ Position of polymorphic sites } \\
\hline & 51 & 52 & 53 & 54 & 154 & 163 & 230 & 246 & 256 & 296 & 317 & 362 & 373 & 404 & 491 \\
\hline S.exelliptica & - & - & - & - & $\mathrm{T}$ & G & $\mathrm{C}$ & A & $\mathrm{C}$ & $\mathrm{G}$ & $\mathrm{G}$ & $\mathrm{T}$ & G & $\mathrm{C}$ & A \\
\hline S.agami & - & - & - & - & $\mathrm{T}$ & $\mathrm{G}$ & - & A & $\mathrm{C}$ & $\mathrm{G}$ & $\mathrm{G}$ & $\mathrm{T}$ & $\mathrm{G}$ & $\mathrm{C}$ & A \\
\hline S.resinosa & $\mathrm{A}$ & - & - & - & $\mathrm{T}$ & $\mathrm{G}$ & - & A & $\mathrm{C}$ & $\mathrm{G}$ & $\mathrm{G}$ & $\mathrm{T}$ & $\mathrm{G}$ & $\mathrm{C}$ & $\mathrm{A}$ \\
\hline S.confusa & - & - & - & - & $\mathrm{T}$ & $\mathrm{G}$ & - & $\mathrm{A}$ & $\mathrm{C}$ & $\mathrm{G}$ & $\mathrm{G}$ & $\mathrm{T}$ & $\mathrm{G}$ & $\mathrm{C}$ & $\mathrm{A}$ \\
\hline S.symingtonii & - & - & - & - & $\mathrm{T}$ & $\mathrm{G}$ & - & $\mathrm{A}$ & $\mathrm{C}$ & $\mathrm{G}$ & $\mathrm{G}$ & $\mathrm{T}$ & $\mathrm{G}$ & $\mathrm{C}$ & $\mathrm{A}$ \\
\hline S.assamica & - & - & - & - & $\mathrm{T}$ & G & - & $\mathrm{R}$ & $\mathrm{C}$ & $\mathrm{G}$ & $\mathrm{G}$ & $\mathrm{T}$ & $\mathrm{G}$ & $\mathrm{C}$ & $\mathrm{A}$ \\
\hline S.brachteolata & $\mathrm{A}$ & $\mathrm{A}$ & A & A & $\mathrm{T}$ & G & - & $\mathrm{R}$ & $\mathrm{Y}$ & $\mathrm{G}$ & $\mathrm{K}$ & $\mathrm{Y}$ & G & $\mathrm{C}$ & $\mathrm{A}$ \\
\hline Dry.oblongifolia & - & - & - & - & $\mathrm{C}$ & $\mathrm{G}$ & $\mathrm{T}$ & $\mathrm{G}$ & $\mathrm{C}$ & $\mathrm{G}$ & $\mathrm{G}$ & $\mathrm{T}$ & $\mathrm{G}$ & $\mathrm{A}$ & $\mathrm{A}$ \\
\hline S. roxburghii & $\mathrm{A}$ & - & - & - & $\mathrm{T}$ & $\mathrm{G}$ & - & $\mathrm{G}$ & $\mathrm{C}$ & $\mathrm{T}$ & $\mathrm{G}$ & $\mathrm{T}$ & $\mathrm{T}$ & $\mathrm{C}$ & $\mathrm{C}$ \\
\hline S. henryana & - & - & - & - & $\mathrm{T}$ & A & - & $\mathrm{G}$ & $\mathrm{T}$ & $\mathrm{T}$ & $\mathrm{K}$ & $\mathrm{C}$ & $\mathrm{C}$ & $\mathrm{C}$ & $\mathrm{A}$ \\
\hline S. lepida & - & - & - & - & $\mathrm{T}$ & A & - & $\mathrm{G}$ & $\mathrm{T}$ & $\mathrm{T}$ & $\mathrm{K}$ & $\mathrm{C}$ & $\mathrm{C}$ & $\mathrm{C}$ & $\mathrm{A}$ \\
\hline
\end{tabular}

1 a Site 51 is (-)

b If (A)

$2 b$

2 a Site 52 is (-)

$3 a$

b If (A)

$3 b$

C If (-)

$3 c$

3 a Site 53 is (-)

$4 a$

$b$ If $(A)$

$4 b$

c If (-)

$4 c$

4 a Site 54 is (-)

$5 a$

b If (A)

$5 b$

c If (-)

$5 c$

5 a Site 154 is (T)

$6 a$ 
b If (C)

6 a Site 163 is (A)

b If (G)

c If (G)

7 a Site 230 is (-)

b If (C)

C If (-)

8 a Site 246 (R)

b If $(A)$

C If $(A)$

d If (G)
Dry. oblongifolia

S.henryana, S. lepida

$7 a$

7c

$8 a$

S. exelliptica

$8 c$

S. assamica

S. agami, S. confusa, S. symingthonii

S. resinosa

S. roxburghii 


\section{Clade 28}

\begin{tabular}{|c|c|c|c|c|c|c|c|c|c|c|c|c|c|c|c|c|}
\hline \multirow{2}{*}{ Species } & \multicolumn{16}{|c|}{ Position of polymorphic sites } \\
\hline & 51 & 140 & 197 & 241 & 248 & 272 & 273 & 274 & 275 & 279 & 280 & 283 & 286 & 289 & 288 & 289 \\
\hline A. costata & - & $\mathrm{C}$ & A & $\mathrm{G}$ & $\mathrm{G}$ & $\mathrm{C}$ & - & - & $\mathrm{C}$ & $\mathrm{T}$ & $\mathrm{T}$ & $\mathrm{T}$ & A & A & A & A \\
\hline C.lanceolatum & A & $\mathrm{C}$ & $\mathrm{C}$ & A & A & $\mathrm{C}$ & $\mathrm{T}$ & $\mathrm{T}$ & A & A & $\mathrm{A}$ & $\mathrm{C}$ & $\mathrm{T}$ & $\mathrm{T}$ & $\mathrm{T}$ & $\mathrm{T}$ \\
\hline$V$. cinerea & - & $\mathrm{C}$ & A & A & A & A & - & - & $\mathrm{C}$ & $\mathrm{T}$ & $\mathrm{T}$ & $\mathrm{T}$ & $\mathrm{A}$ & A & A & A \\
\hline V. odorata & - & $\mathrm{C}$ & $\mathrm{A}$ & A & $\mathrm{A}$ & $\mathrm{C}$ & - & - & $\mathrm{C}$ & $\mathrm{T}$ & $\mathrm{T}$ & $\mathrm{T}$ & $\mathrm{A}$ & A & $\mathrm{A}$ & A \\
\hline V.philastreana & - & $\mathrm{C}$ & $\mathrm{A}$ & A & $\mathrm{A}$ & $\mathrm{C}$ & - & - & $\mathrm{C}$ & $\mathrm{T}$ & $\mathrm{T}$ & $\mathrm{T}$ & $\mathrm{A}$ & A & $\mathrm{A}$ & A \\
\hline V. subglabra & - & $\mathrm{C}$ & $\mathrm{A}$ & A & $\mathrm{A}$ & $\mathrm{A}$ & - & - & $\mathrm{C}$ & $\mathrm{T}$ & $\mathrm{T}$ & $\mathrm{T}$ & $\mathrm{A}$ & $\mathrm{A}$ & $\mathrm{A}$ & A \\
\hline U. borneensis & - & $\mathrm{T}$ & A & A & A & $\mathrm{C}$ & - & - & $\mathrm{C}$ & $\mathrm{T}$ & $\mathrm{T}$ & $\mathrm{T}$ & A & A & A & A \\
\hline
\end{tabular}

\begin{tabular}{|c|c|c|c|c|c|c|c|c|c|c|c|c|c|c|c|c|c|c|c|c|c|c|c|}
\hline 291 & 296 & 298 & 299 & 315 & 316 & 317 & 320 & 321 & $\begin{array}{r}330- \\
331 \\
\end{array}$ & 325 & 327 & 342 & 343 & 344 & 351 & 353 & 357 & 380 & 381 & 382 & $384-388$ & $\begin{array}{l}391- \\
392\end{array}$ & 481 \\
\hline $\mathrm{T}$ & $\mathrm{G}$ & A & A & A & $\mathrm{A}$ & $\mathrm{G}$ & $\mathrm{T}$ & $\mathrm{T}$ & AA & $\mathrm{T}$ & A & $\mathrm{C}$ & $\mathrm{G}$ & $\mathrm{T}$ & $\mathrm{T}$ & G & $\mathrm{T}$ & $\mathrm{G}$ & $\mathrm{A}$ & A & CAAAT & $\mathrm{AA}$ & $\mathrm{G}$ \\
\hline $\mathrm{C}$ & A & $\mathrm{T}$ & $\mathrm{T}$ & $\mathrm{T}$ & A & A & A & A & -- & 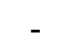 & A & A & G & G & G & A & $\mathrm{C}$ & 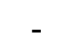 & - & $\mathrm{C}$ & 0 & 0 & $\mathrm{C}$ \\
\hline $\mathrm{T}$ & G & $\mathrm{A}$ & $\mathrm{A}$ & $\mathrm{A}$ & $\mathrm{A}$ & $\mathrm{G}$ & $\mathrm{T}$ & $\mathrm{T}$ & AA & $\mathrm{T}$ & $\mathrm{M}$ & $\mathrm{C}$ & $\mathrm{C}$ & $\mathrm{G}$ & $\mathrm{T}$ & $\mathrm{G}$ & $\mathrm{T}$ & $\mathrm{G}$ & $\mathrm{A}$ & $\mathrm{A}$ & CAAAT & $\mathrm{AA}$ & $\mathrm{C}$ \\
\hline $\mathrm{T}$ & $\mathrm{G}$ & A & A & A & A & $\mathrm{G}$ & $\mathrm{T}$ & $\mathrm{T}$ & AA & $\mathrm{T}$ & A & $\mathrm{C}$ & $\mathrm{C}$ & $\mathrm{G}$ & $\mathrm{T}$ & G & $\mathrm{T}$ & G & A & A & CAAAT & $\mathrm{AA}$ & $\mathrm{C}$ \\
\hline $\mathrm{T}$ & G & A & A & A & A & $\mathrm{G}$ & $\mathrm{T}$ & $\mathrm{T}$ & AA & $\mathrm{T}$ & $\mathrm{A}$ & $\mathrm{C}$ & $\mathrm{G}$ & $\mathrm{G}$ & $\mathrm{T}$ & $\mathrm{G}$ & $\mathrm{T}$ & G & A & $\mathrm{A}$ & CAAAT & AA & $\mathrm{C}$ \\
\hline $\mathrm{T}$ & $\mathrm{G}$ & A & A & A & A & $\mathrm{G}$ & $\mathrm{T}$ & $\mathrm{T}$ & AA & $\mathrm{T}$ & A & $\mathrm{C}$ & $\mathrm{C}$ & $\mathrm{G}$ & $\mathrm{T}$ & G & $\mathrm{T}$ & $\mathrm{G}$ & A & A & CAAAT & $\mathrm{AA}$ & $\mathrm{C}$ \\
\hline $\mathrm{T}$ & $\mathrm{G}$ & A & A & A & $\mathrm{G}$ & $\mathrm{G}$ & $\mathrm{T}$ & $\mathrm{T}$ & AA & $\mathrm{T}$ & $\mathrm{A}$ & $\mathrm{C}$ & $\mathrm{G}$ & $\mathrm{G}$ & $\mathrm{T}$ & $\mathrm{G}$ & $\mathrm{T}$ & $\mathrm{G}$ & A & $\mathrm{A}$ & CAAAT & $\mathrm{AA}$ & $\mathrm{C}$ \\
\hline
\end{tabular}




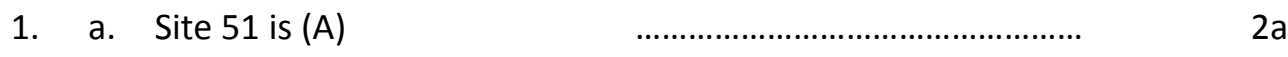

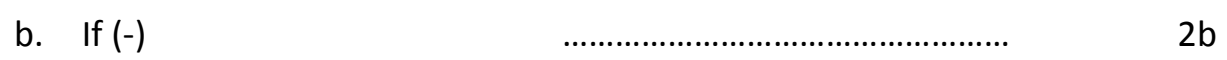

2. a. Site $84-89$ is (AAAAGC) …..........................................

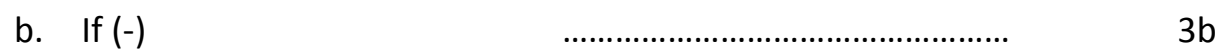

3. a. Site 140 is $(\mathrm{T}) \quad$............................................... borneensis

b. If $(\mathrm{C})$

4. $\quad$ a. 197 is $(A)$
b. If (C)
C. lanceolatum

5. a. Site 241 is (G)

A. costata

b. If $(A)$

6

6. a. Site 272 is (A)

$7 a$

b. If ((C)

$7 b$

7. a. Site 327 is (M)

V. cinerea

b. If $(A)$

V. suglabra

c. If $(A)$

8

8. a Site 343 is (C)

V. odorata

b If (G)

V. philastreana 


\section{Clade 29}

\begin{tabular}{|l|r|r|l|l|l|l|l|l|}
\hline \multirow{2}{*}{\multicolumn{1}{|c|}{ Species }} & \multicolumn{7}{|c|}{ Position of polymorphic sites } \\
\cline { 2 - 10 } & 8 & 51 & 81 & 155 & 193 & $301-314$ & 340 & 525 \\
\hline D. alatus & - & - & A & G & C & ---------- & A & A \\
\hline D. baudii & - & A & A & G & C & TAGGTTATAGCAAA & A & A \\
\hline D. condorensis & - & A & A & G & C & TAGGTTATAGCAAA & A & A \\
\hline D. costatus & - & - & A & G & C & TAGGTTATAGCAAA & G & A \\
\hline D. dyerii & - & - & C & G & C & TAGGTTATAGCAAA & A & A \\
\hline D. grandiflorus & - & - & A & G & C & TAGGTTATAGCAAA & A & A \\
\hline D. haseltii & - & - & A & G & C & TAGGTTATAGCAAA & G & A \\
\hline D. intricatus & - & - & A & R & T & TAGGTTATAGCAAA & A & A \\
\hline D. kerii & - & - & A & G & C & TAGGTTATAGCAAA & A & A \\
\hline D. obtusifolius & G & - & A & G & C & TAGGTTATAGCAAA & A & A \\
\hline D. tempehes & - & - & A & G & C & TAGGTTATAGCAAA & A & A \\
\hline D. tuberculatus & - & - & A & G & C & TAGGTTATAGCAAA & A & R \\
\hline D. turbinatus & - & - & A & G & C & TAGGTTATAGCAAA & A & A \\
\hline
\end{tabular}


1. a. Site 8 is $(-)$

$2 a b$

b. If $(G)$

$2 c$

2. a. Site 51 is (-)

$3 a$

b. If $(A)$

D. baudii, $D$. condorensis

c If (-)

$3 c$

3. a. Site 81 is (A)

$4 a$

b. If (C)

D. dyerii

c. If $(A)$

D. obtusifolius

4. a. Site 155 is $(G)$

$5 a$

b. If (R)

$5 b$

5. a. Site 193 is (C)

$6 a$

b. If $(T)$

D. intricatus

6. a. Site $301-314$ is (-----------)

D. alatus

b. If (TAGGTTATAGCAAA)

7. a. Site 340 is (A)

$8 a$

b. If $(G)$

$8 b$

8. a Site 525 is $(\mathrm{A})$

D.

grandiflorus,

D. kerii, $D$.

tempehes, $D$.

turbinatus

b If (G)

D. costatus, $D$. haseltii 


\section{PERSONAL}

\begin{tabular}{|c|c|c|}
\hline Name & : & Essy Harnelly \\
\hline Place/date of birth & : & Banda Aceh, 9 January 1975 \\
\hline Sex & : & Female \\
\hline Marital status & : & Married \\
\hline Official Position & : & $\begin{array}{l}\text { Lecturer at Biology Department in Mathematics and Natural } \\
\text { Science Faculty, Syiah Kuala University- Banda Aceh- } \\
\text { Indonesia }\end{array}$ \\
\hline Home address & & $\begin{array}{l}\text { Jl. Mesjid Ashadaqah Lr. Assyura no } 12 \text { Lamlagang, Banda } \\
\text { Aceh - Indonesia. } 23239\end{array}$ \\
\hline E-mail & : & eharnelly@gmail.com or ehusin@gwdg.de \\
\hline
\end{tabular}

\section{EDUCATIONAL BACKGROUND}

1. $1993-1998$

2. $1998-2003$

3. 2009-2013
: Bachelor Degree in Biology (Faculty of Mathematic and Natural Sciences, University of Syiah Kuala, Banda Aceh)

: Magister of Sains in Biology (Bogor Agricultural Institute)

: Doctoral study at the Institute of Forest Genetics and Forest Tree Breeding, Georg-August University of Goettingen, Germany

\section{WORKING EXPERIENCES}

2000 - Present

: Lecturer staff in Biology Department, Syiah Kuala University, Banda Aceh Indonesia.

\section{PUBLICATION}

Harnelly, Essy., Prinz, Kathleen., and Finkeldey, Reiner., 2012. Suitability of the Two Barcoding Regions matK and $r b c \mathrm{~L}$ to dicriminate Dipeterocarpaceae. Poster Presented at Third European Conference For the Barcode of Life. Belgium 17 - 20 September 2012. 